\title{
Mongolia: Selected Issues and Statistical Appendix
}

This Selected Issues paper and Statistical Appendix for Mongolia was prepared by a staff team of the International Monetary Fund as background documentation for the periodic consultation with the member country. It is based on the information available at the time it was completed on December 22, 2006. The views expressed in this document are those of the staff team and do not necessarily reflect the views of the government of Mongolia or the Executive Board of the IMF.

The policy of publication of staff reports and other documents by the IMF allows for the deletion of market-sensitive information.

To assist the IMF in evaluating the publication policy, reader comments are invited and may be sent by e-mail to publicationpolicy@imf.org.

Copies of this report are available to the public from

International Monetary Fund • Publication Services

700 19th Street, N.W. • Washington, D.C. 20431

Telephone: (202) 6237430 • Telefax: (202) 6237201

E-mail: publications@imf.org• Internet: http://www.imf.org

Price: $\$ 18.00$ a copy

\section{International Monetary Fund Washington, D.C.}





\section{INTERNATIONAL MONETARY FUND}

MONGOLIA

\section{Selected Issues and Statistical Appendix}

Prepared by Philippe Marciniak, Seungho Lee (All APD), Wu Yi (PDR), Selim Cakir (MCD), Alexander Klemm (EUR), Yinqiu Lu (AFR)

Approved by Asia and Pacific Department

December 22, 2006

Contents

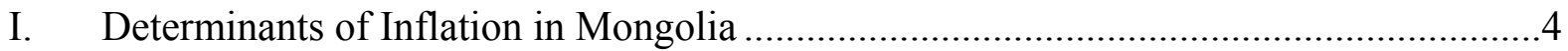

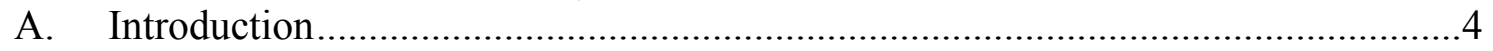

B. Recent CPI and Monetary Aggregates Developments......................................5

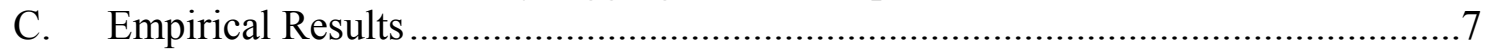

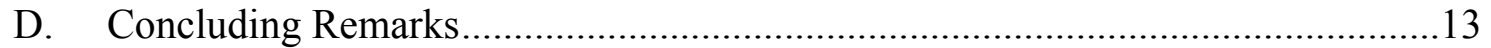

Annex: Estimation Results of the Structural Model ........................................14

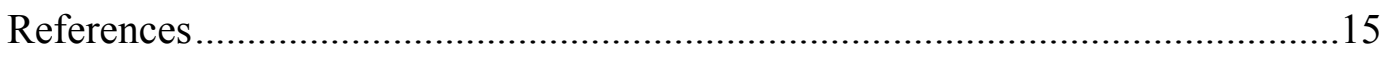

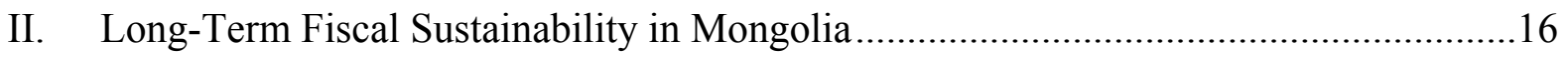

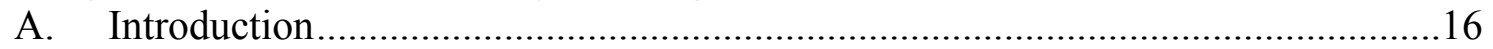

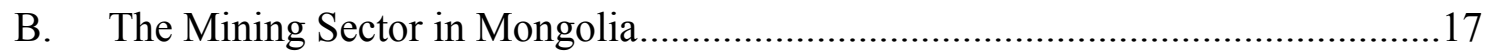

C. Mongolia's Mineral Wealth .......................................................................... 21

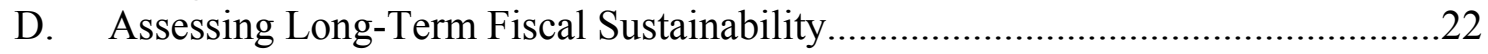

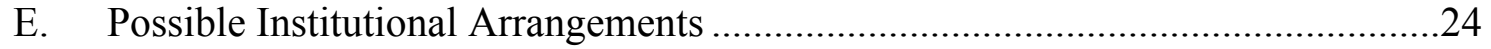

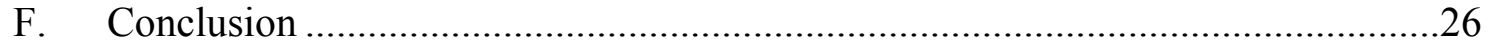

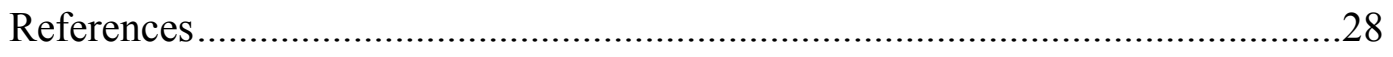

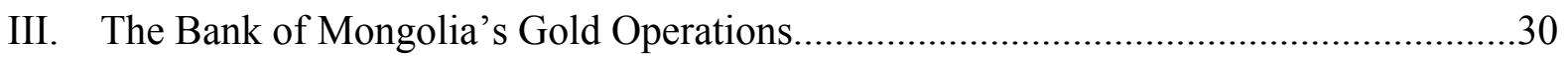

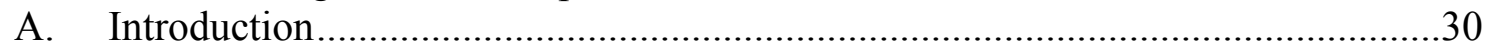

B. The BOM's Involvement in the Domestic Gold Market ...................................30

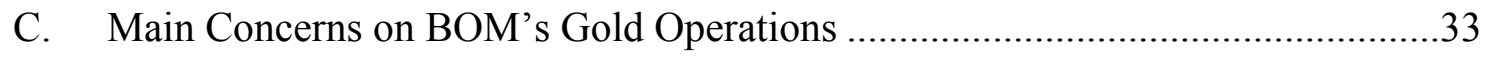

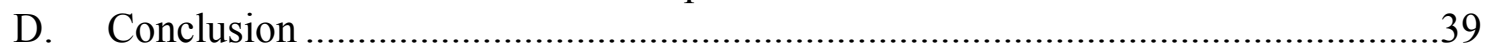

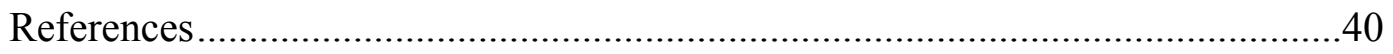

IV. Foreign Exchange Market in Mongolia ............................................................ 
Boxes

I.1. Empirical Method Using the Structural Model.........................................................

I.2. Empirical Method Using VAR Model....................................................................11

II.1. Assumptions Underlying Mineral Wealth Calculations ...........................................21

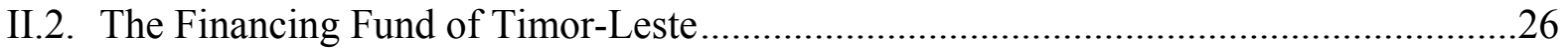

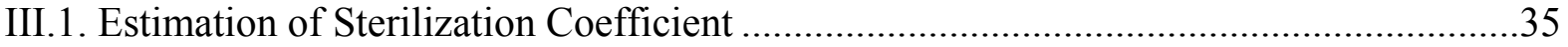

IV.1. Does BOM's Midpoint Rate Affect the Market Rate?. ..............................................46

Statistical Appendix Tables

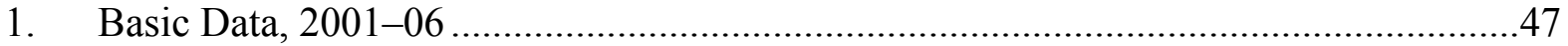

2. GDP Deflator by Sector at Current Market Prices, 2001-05 …...................................48

3. GDP by Sector at 2000 Constant Prices, 2001-05 …................................................49

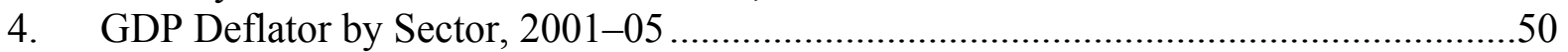

5. Gross National Disposable Income and Savings at Current

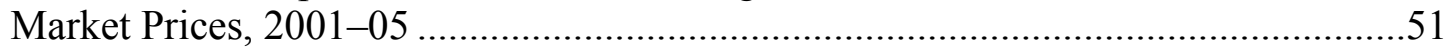

6. Output of Major Agricultural Products, 2001-05 ...................................................52

7. Output of Basic Industrial and Mining Products, 2001-05 .......................................53

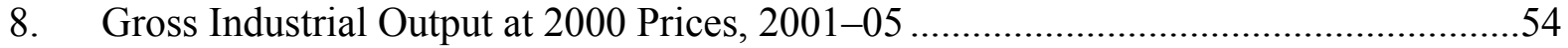

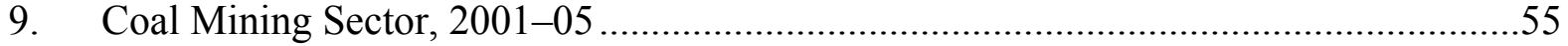

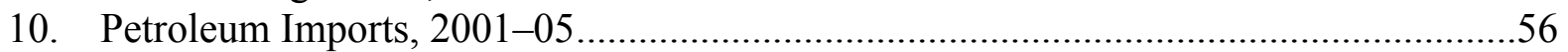

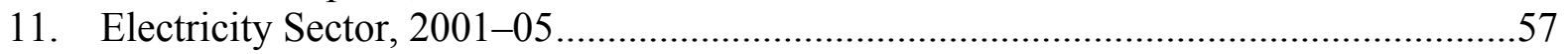

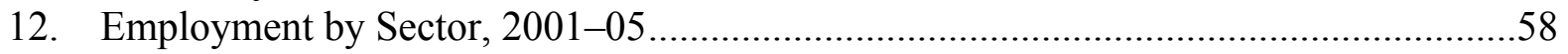

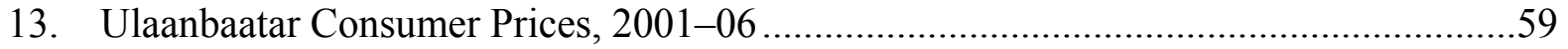

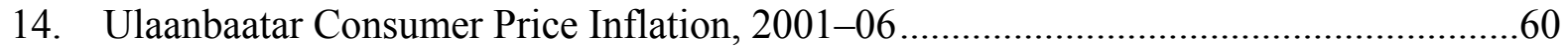

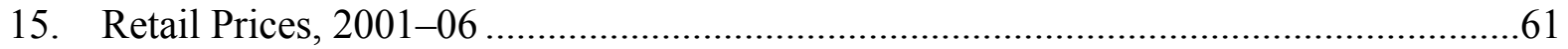

16. Privatization of State-Owned Enterprises, 2001-05 ................................................62

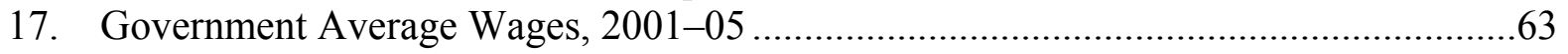

18. Summary Operations of the General Government, 2002-06...................................64

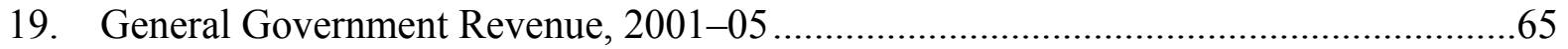

20. General Government Expenditure, 2001-05 ..........................................................66

21. General Government Expenditure by Function, 2001-06 .........................................67

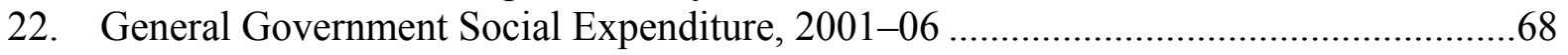

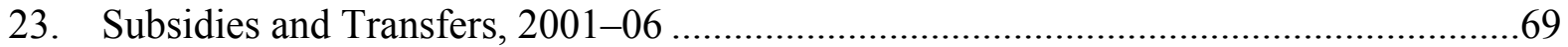

24. Social Security and Social Assistance Funds, 2001-06..........................................70

25. Number of Social Security Beneficiaries, 2001-06.................................................... 71

26. Government Employment and Wage Bill, 2001-06.............................................. 72

27. Expenditure of the Health Sector, 2001-06 ...........................................................73

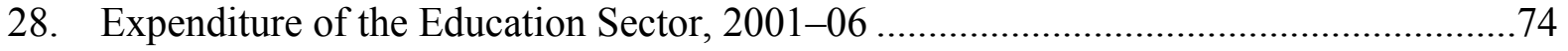

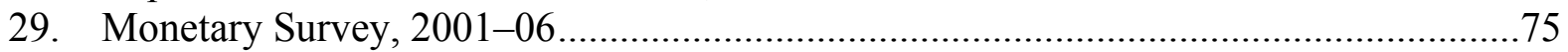

30. Balance Sheet of the Bank of Mongolia, 2001-06 ....................................................76

31. Consolidated Balance Sheet of Commercial Banks, 2001-06..................................77

32. Distribution of Bank Credit to the Nongovernment Sector, 2001-06 .........................78

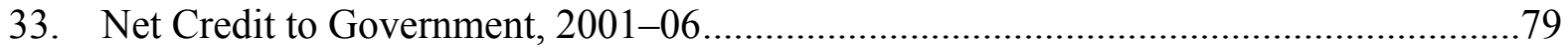




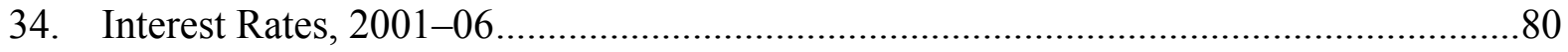

35. Financial Soundness Indicators for Banking Sector, 2001-06 …….............................. 81

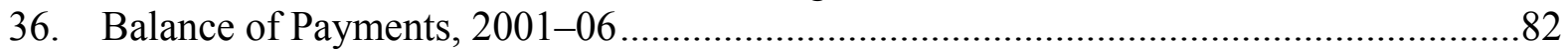

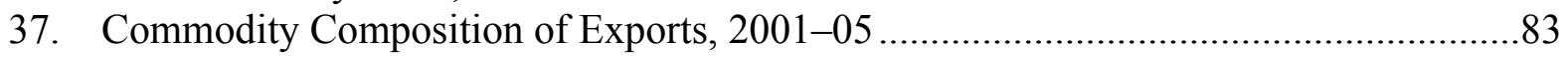

38. Commodity Composition of Imports, 2001-05 ……..................................................8

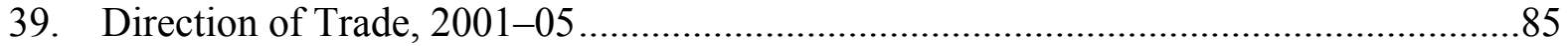

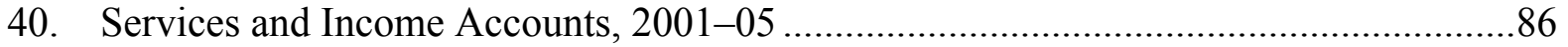

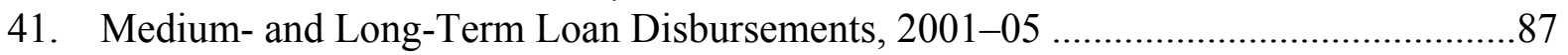

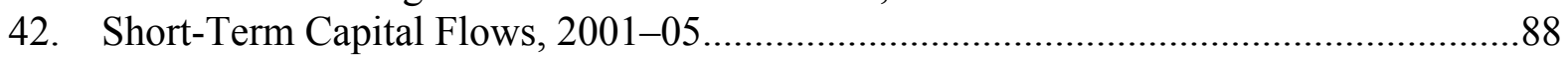

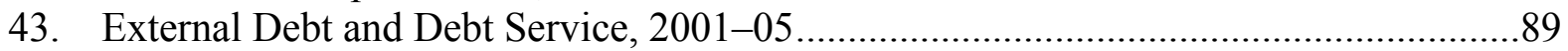

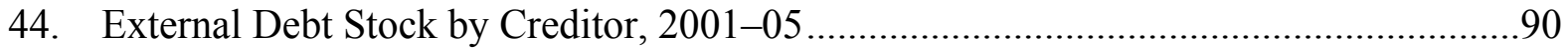

45. Official Reserves of the Bank of Mongolia, 2001-06 ................................................91

46. Selected Indicators of Commercial Bank Foreign

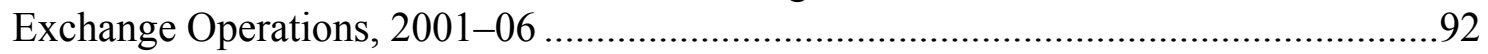

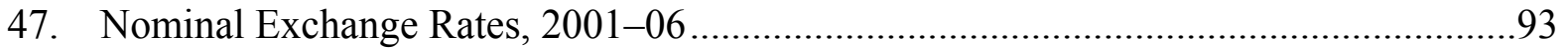




\section{DETERminants OF INFLATION IN MONGOLiA ${ }^{1}$}

\section{A. Introduction}

1. Despite robust demand growth, inflation in Mongolia has been generally moderate in recent years. Inflation, as measured by the end-of-period consumer price index $(\mathrm{CPI})^{2}$ averaged 7.4 percent during $2000-05$ and is estimated at 7.0 percent in 2006 . The moderate inflation in the 2000s' is in a sharp contrast with the 1990s. In the early $1990 \mathrm{~s}$, when Mongolia recorded triple digit inflation in 1993-94 and an average inflation rate of nearly 20 percent during 1995-2000. The moderation of inflation in recent years has taken place despite rapid monetary expansion. During 2000-05, broad money expanded by 32.4 percent and reserve money increased by 16.8 percent, rates much higher than inflation.

2. These somewhat surprising developments reflect the variety of factors-both real and monetary - that are found to influence inflation in Mongolia. It is widely agreed that the relative inelasticity of food supply, especially meat products in Mongolia, is a key contributor to the inflationary process, regardless of money supply developments. ${ }^{3}$ Import prices, especially for petroleum products, are also potential sources of inflationary pressures, given the large share of imported goods and raw materials in Mongolia's consumer basket take. Changes in world commodity prices (e.g., copper and gold) can also indirectly lead to inflation changes in both directions. That is, a surge in foreign exchange inflows from commodity price hikes brings about liquidity expansion, thereby inflationary pressures, while it could partly offset inflationary pressures, given that exchange rate appreciation arises due to the capital inflows. Loose government spending (e.g., wages, pensions, and social transfers) may cause potential inflationary impacts as well, although those factors are not the main focus in this chapter.

\section{The extent to which low inflation can be sustained under rapid monetary} expansion and high mineral prices remains uncertain. This chapter analyzes the main determinants of inflation in Mongolia using empirical tests based on a structural model approach and VAR (Vector Autoregression Model), with a view to assessing whether inflation is predominantly affected by commodity prices or by money supply developments. To that end, simulation and impulse response analyses are used to estimate the components of the inflation dynamics under various exogenous shocks. Although inflation is strongly

\footnotetext{
${ }^{1}$ Prepared by SeungHo Lee.

2 Since April 2006, Mongolia's NSO (National Statistical Office) has expanded the number of items in the CPI basket from 239 to 287 and changed the base year to December $2005=100$.

${ }^{3}$ Mongolia's consumer basket includes meat and meat products (12.5 percent), dairy products (5.2 percent), and fruits and vegetables (9.0 percent), which are excluded in Fund staff's estimation of core inflation. Even though core inflation is a proper alternative to assess the monetary impact on inflation, in this chapter the overall CPI was used as an inflation proxy because of data limitations and its importance as a key monetary policy target.
} 
influenced by exogenous shocks to meat, copper, and oil import prices, we find that monetary expansion and changes in exchange rate are also critical determinants of inflation.

\section{B. Recent CPI and Monetary Aggregates Developments}

\section{Inflation was relatively} volatile in 2005 due to a severe shortage of meat supply, reaching its recent peak of 17.6 percent (y/y) in June 2005. As the supply shock was reversed from the third quarter of 2005, inflationary pressures abated quickly, with the CPI increasing by only 1.8 percent $(\mathrm{y} / \mathrm{y})$ in July 2006, the lowest in four years. However, with the waning influence of the supply shock, inflation picked up to 6.8 percent

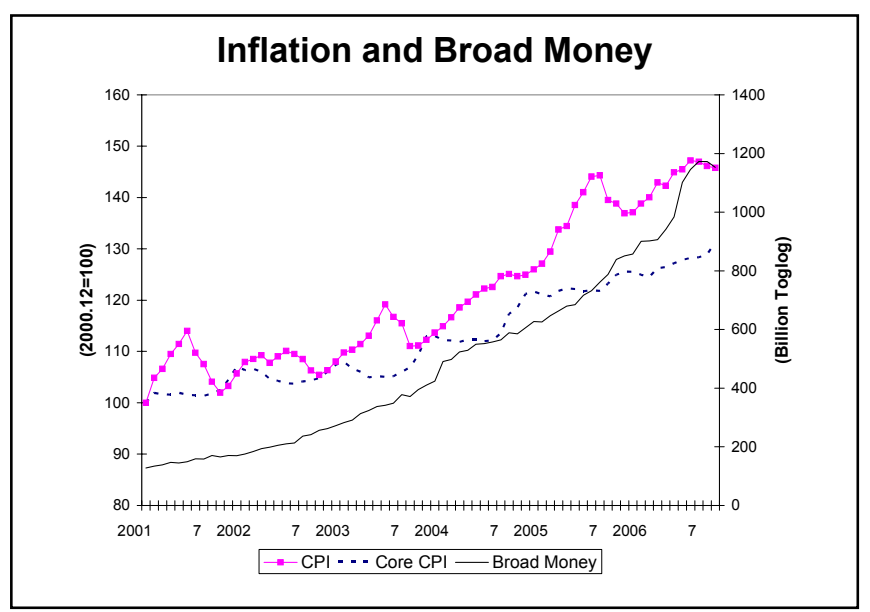
(y/y) at end-November 2006. The exchange rate appreciation due to the strengthening of the external position, has also contributed to suppress inflationary pressures. However, core inflation as of November was 6.7 percent $(y / y)$, a relatively high increase in comparison to the overall CPI. This may imply that inflationary pressures driven by the demand side of the economy is significant this year.

\begin{tabular}{|c|c|c|c|c|c|c|c|}
\hline \multicolumn{8}{|c|}{$\begin{array}{l}\text { Inflation and Broad Money } \\
\text { (In percent) }\end{array}$} \\
\hline & 2000 & 2001 & 2002 & 2003 & 2004 & 2005 & 2006 \\
\hline $\mathrm{CPI}^{1 /}$ & 8.1 & 7.9 & 1.7 & 4.7 & 10.6 & 9.2 & $6.8^{2)}$ \\
\hline Core Inflation ${ }^{1 /}$ & - & 4.3 & 1.3 & 5.2 & 8.0 & 3.5 & $6.7^{2)}$ \\
\hline Broad Money & 17.5 & 28.0 & 41.9 & 49.7 & 20.3 & 37.3 & $38.3^{4)}$ \\
\hline Togrog/U.S.\$ ${ }^{3 /}$ & -2.2 & -0.5 & -2.0 & -3.8 & -3.2 & -1.0 & $+4.9^{2) 5)}$ \\
\hline \multicolumn{8}{|c|}{$\begin{array}{l}\text { 1/ Year on year. } \\
\text { 2/ End-November. } \\
\text { 3/ End of period, (+)/(-) indicates an appreciation/depreciation. } \\
\text { 4/ End-October. } \\
\text { 5/ Since end-2005. }\end{array}$} \\
\hline
\end{tabular}




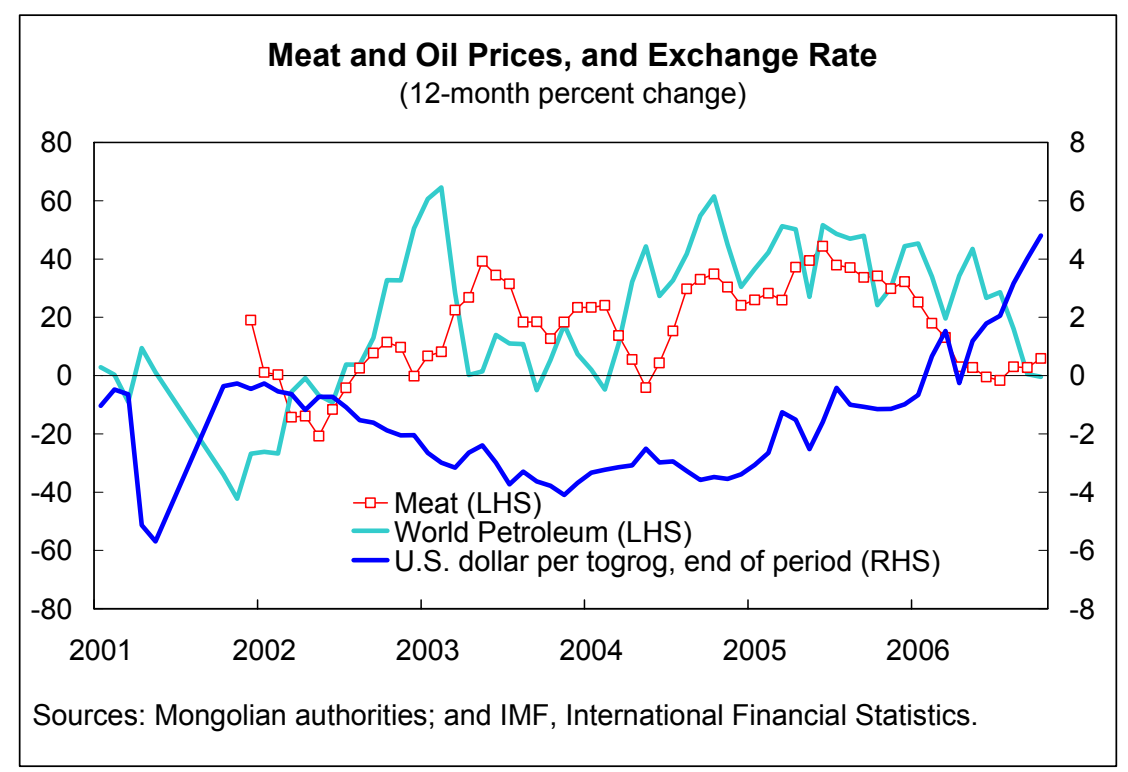

5. The limited inflationary response to rapidly increasing money supply largely reflects a still strong monetization process, which is still underway. In other words, as income rises, the private sector expands with large increase in deposit into and borrowing from banking system. Total deposit in the banking system in relation to nominal GDP almost doubled during 2000 and 2006, while the money multiplier steadily increased from 1.9 in 2000 to 4.8 in 2006. Since 2000, the pace of credit expansion to private sector seems to outpace that of deposit increases in the banking system.

\begin{tabular}{|lcccccccc|}
\hline \multicolumn{1}{c}{ Indicators of Remonetization } \\
(In percent)
\end{tabular}

6. The degree of remonetization seems more pronounced in Mongolia than in other Commonwealth of Independent States (CIS) countries. At end-2005, credit to the private sector in Mongolia as share of GDP reached its highest level of 37.5 percent, compared with 36.3 percent in Kazakhstan, 33.5 percent in Ukraine, and much lower levels in other countries. Furthermore, the pace of the credit expansion to the private sector is the fastest in Mongolia during the period 2000-05, increasing by almost fivefold in five years. 


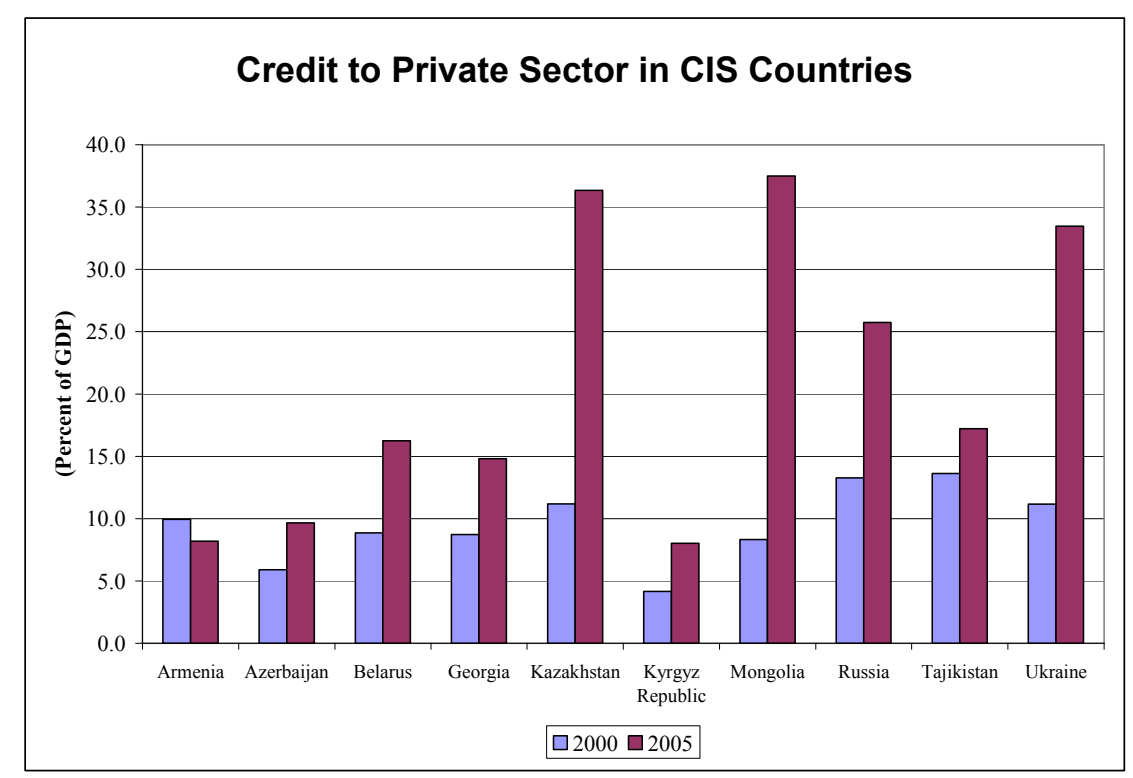

C. Empirical Results

\section{Structural Model}

7. To identify the dominant factors affecting inflation, six endogenous variables (CPI, broad money, reserve money, exchange rate, export and import) are estimated by simple OLS regressions in a structural model. Quarterly data are used during the sample period of 1993 Q1-2006 Q1. To consider a strong seasonality in the Mongolian economy, seasonal dummy variables are included (Box I.1).

8. The coefficients of the explanatory variables in the six estimation equations show expected signs in most cases (see Annex). Inflation is positively related to increases in broad money, increases in copper and oil prices and the depreciation of togrog. The statistical significance of the coefficients, however, is not robust except for the exchange rate. Broad money is positively affected by an increase in reserve money and the second quarter seasonal dummy variable. However, broad money is negatively affected by the depreciation of the exchange rate. Reserve money supply is positively related to the increase in lending interest rates, reflecting high money demand in the money market. ${ }^{4}$ The exchange rate is influenced by the supply and demand of foreign exchange, which is mostly envisaged in exports and imports, respectively. ${ }^{5}$ The exports are positively affected by increase in copper price and exchange rate depreciation, while the imports are insignificantly influenced by world oil prices.

\footnotetext{
${ }^{4}$ Central Bank Bill rates instead of lending rates could be a good alternative as an explanatory variable for reserve money. However, because of the lack of interest rate signaling channel of CBBs as a policy instrument, lending rates are used to capture the magnitude of money demand in the economy.

${ }^{5}$ Because of the inaccessibility of quarterly data in the sample period, foreign remittances were not included in the estimation.
} 
Box I.1. Empirical Method Using the Structural Model

Data

- $\quad$ Estimation Period: 1993 Q1 - 2006 Q1

- $\quad$ Frequency: Quarterly

- $\quad$ Number of observations: 53

- $\quad$ All variables are log-transformed.

- Seasonal dummy variables are included to reflect high seasonality.

\section{Structure of the Model}

- $\quad$ Six endogenous variables, including CPI, broad money(BM), reserve money(RM), nominal exchange rate(ER), export(EX) and import(IM) are estimated using OLS. The composition of the structural model is as follows:

$C P I=f($ Constant, BM, ER, OIL(-1), COPP, CPI $\{-1\})$

$B M=f($ Constant $, R M, E R, D U M 2, B M\{-1\})$

$R M=f($ Constant $L R, D 2, R M\{-1\})$

$E R=f($ Constant $, E X, I M, E R\{-1\})$

$E X=f($ Constant, COPP, GOLDP, ER, DUM4, EX $\{-1\})$

$I M=f($ Constant, OIL, EX, CPI, IM $\{-1\})$

\begin{tabular}{|llll|}
\hline & Endogenous Variables & & Exogenous Variables \\
\hline CPI & Consumer Price Index & OIL & Oil price (Brent) \\
BM & Broad Money & COPP & Copper price \\
RM & Reserve Money & GOLDP & Gold price \\
ER & Exchange Rate (period average) & LR & Lending Rates \\
EX & Export & DUM2 & 2nd quarter dummy variable \\
IM & Import & DUM4 & 4th quarter dummy variable \\
\hline
\end{tabular}

- $\quad$ After applying the RMSE test for verifying the stability of the structural model, a policy simulation is applied, in which a certain shock is generated to see the dynamic impacts of each variable on inflation within the structural model.

- $\quad$ The simulation period is 2001 Q1 - 2006 Q1. 
9. The simulation results of this structural model sufficiently fit the statistical criteria of $\mathbf{R M S E}^{6}$ for each estimation equation. RMSEs in each endogenous variable are less than 5 percent, which is in general regarded as a benchmark. The results of the RMSE are as follows:

\begin{tabular}{|ll|}
\hline \multicolumn{2}{|c|}{ Results of RMSE } \\
\hline Endogenous variables & RMSE (percent) \\
\hline CPI & 1.4184 \\
Broad Money & 0.5426 \\
Reserve Money & 0.4823 \\
Exchange Rate & 0.9622 \\
Exports & 4.3878 \\
Imports & 4.2135 \\
\hline
\end{tabular}

10. The empirical results of the policy simulation indicate that inflation in Mongolia is positively affected by increases in copper and oil prices, money growth, and the depreciation of exchange rate. Increases in copper prices have a larger impact on inflation than increases in oil prices. It is estimated that a 10 percent increase in copper prices as a permanent shock causes a 1.29 percent increase in price level (annual average), while a 10 percent increase in oil prices results in a 0.36 percent increase in price level. The impact of gold prices on inflation, however, seems negligible. It is confirmed that the money growth also has significant impact on inflation. It is estimated that a 5 percent increase in reserve and broad money increases the price level (annual average) by 0.27 percent and 0.28 percent, respectively.

\begin{tabular}{|c|c|c|c|c|c|c|}
\hline \multicolumn{7}{|c|}{$\begin{array}{c}\text { Result of Policy Simulations on Inflation } \\
\text { (In percent) }\end{array}$} \\
\hline \multirow{2}{*}{ Permanent Shocks } & \multicolumn{6}{|c|}{ Impact on CPI } \\
\hline & 1st year & 2nd year & 3rd year & $4^{\text {th }}$ year & $5^{\text {th }}$ year & $\begin{array}{c}\text { Annual } \\
\text { average }\end{array}$ \\
\hline $10 \%$ increase in copper price & 0.83 & 1.25 & 1.39 & 1.47 & 1.51 & 1.29 \\
\hline $10 \%$ increase in gold price & -0.05 & -0.04 & -0.04 & -0.03 & -0.03 & -0.04 \\
\hline $10 \%$ increase in oil price & 0.17 & 0.36 & 0.41 & 0.43 & 0.44 & 0.36 \\
\hline $5 \%$ increase in reserve money & 0.06 & 0.19 & 0.30 & 0.38 & 0.44 & 0.27 \\
\hline $5 \%$ increase in broad money & 0.18 & 0.27 & 0.30 & 0.32 & 0.33 & 0.28 \\
\hline $1 \%$ appreciation of Togrog & -0.70 & -0.94 & -0.96 & -0.95 & -0.95 & -0.90 \\
\hline
\end{tabular}

\footnotetext{
${ }^{6} \mathrm{RMSE}=\operatorname{SQRT}\left((1 / \mathrm{T}) * \sum(\mathrm{Ys}-\mathrm{Ya}) / \mathrm{Ya}\right)^{2} * 100$, where T: number of observations in simulation period, Ys: simulated value, Ya: actual value.
} 


\section{Impacts of Selected Shocks on CPI} (In percent)

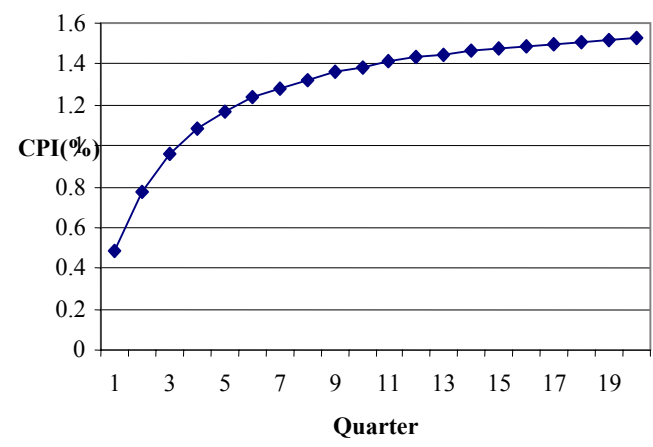

Shock to Copper Prices

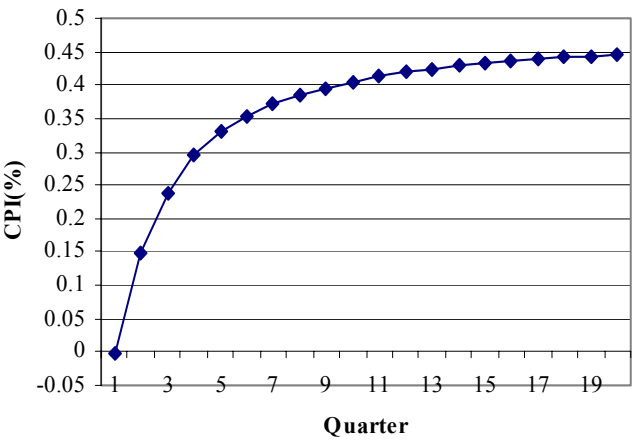

Shock to Oil Prices

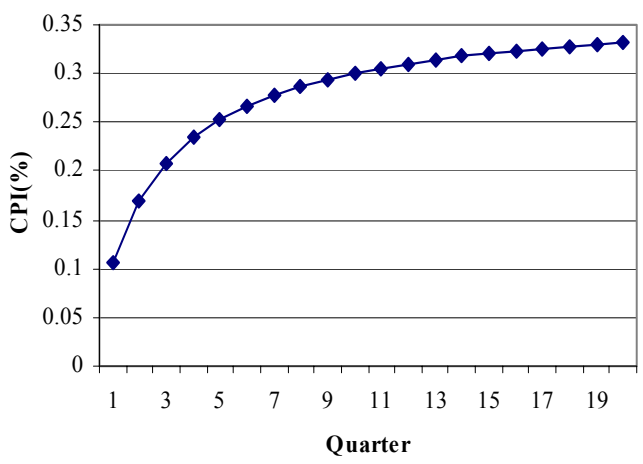

Shock to Broad Money

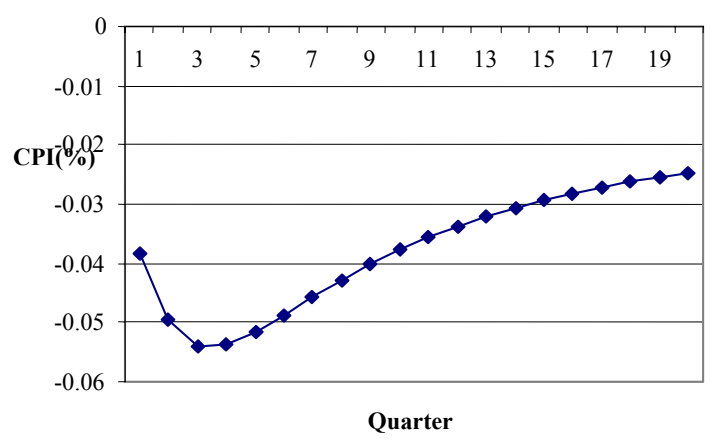

Shock to Gold Prices

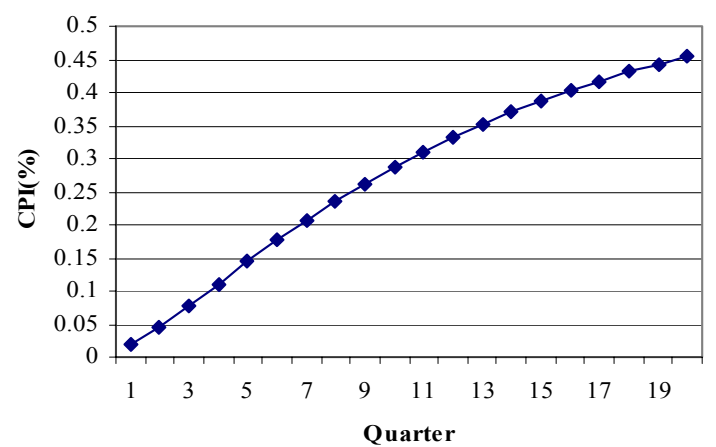

Shock to Reserve Money

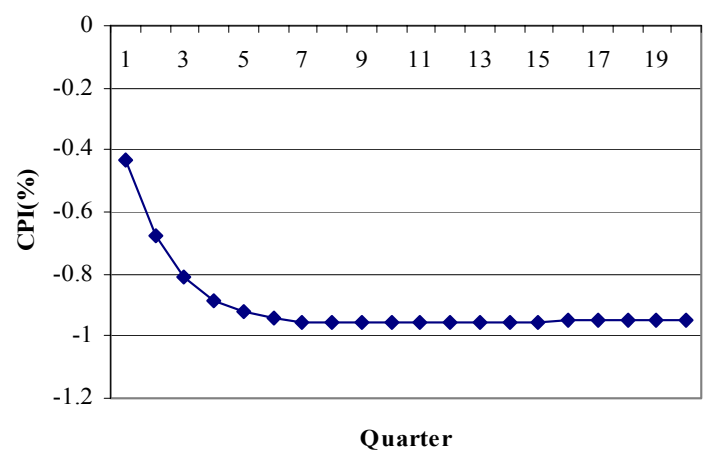

Shock to Togrog Appreciation 


\section{VAR Model}

11. The togrog exchange rate seems to have the largest influence on inflation, implying that the recent appreciation of the togrog may be the main factor behind low inflation in recent months. It is estimated that a 1 percent appreciation of the togrog causes a 0.90 percent decrease in inflation (annual average). It is also noticeable that the impact of the exchange rate shock on inflation occurs with a short time lag, while other shocks seem to have a more gradual impact.

12. The impulse response analyses in the VAR model, which shows a dynamic process of a specific variable to various shocks, confirms broadly the results of the structural model (Box I.2). A one percent standard deviation shock on variables, such as copper prices, oil prices, money supply and the exchange rate affects inflation significantly. Increases in copper prices affect inflation with about a three-month lag, while increases in oil prices have a more rapid impact on inflation. The length of the response, however, is more lasting for copper price changes than oil price changes. The nominal exchange rate depreciation shock has an instant and persistent impact on inflation, confirming the results of the structural model. The money growth shock also seems crucial in affecting inflation. It appears that reserve money growth affects the inflation with about a two-quarter lag, compared with a three-month lag for the increase in broad money.

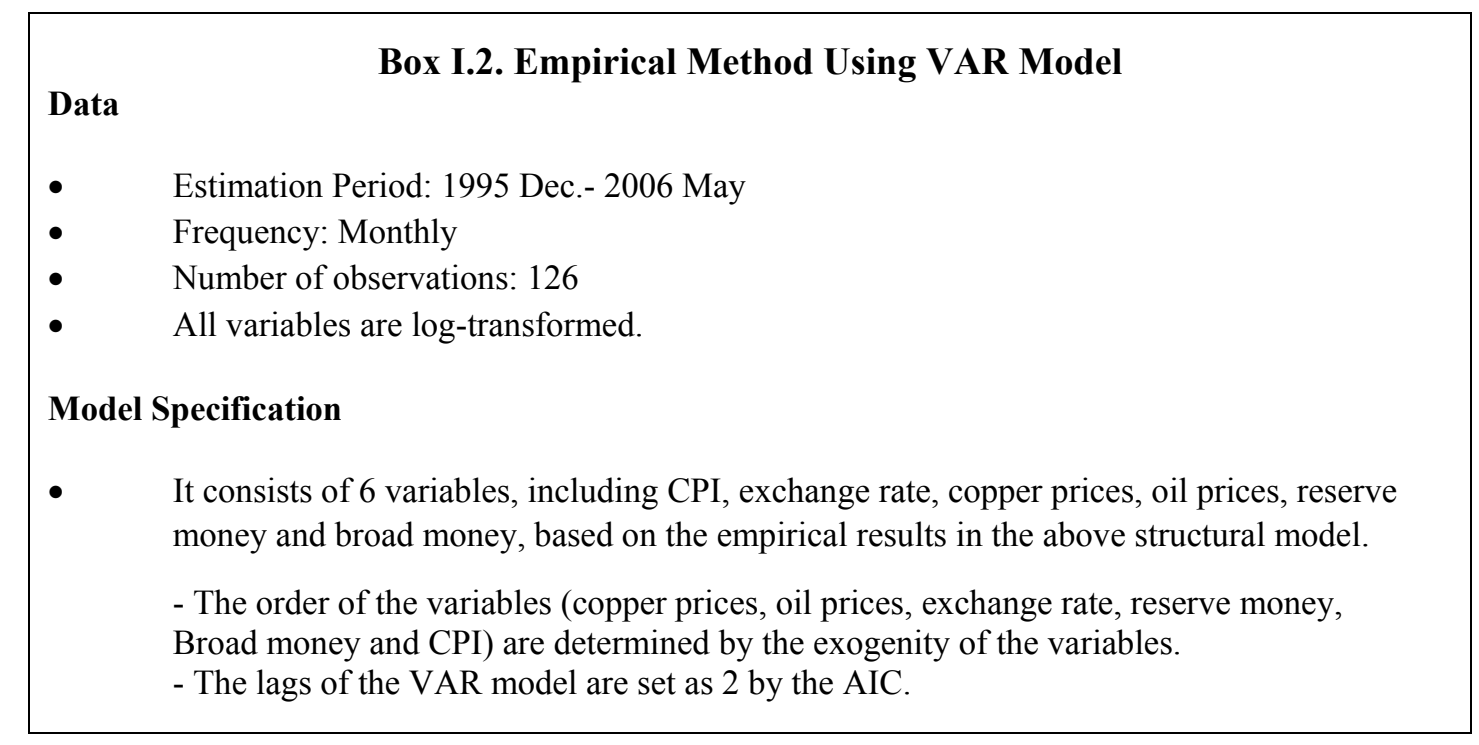


Impulse Response of CPI to Each Shock
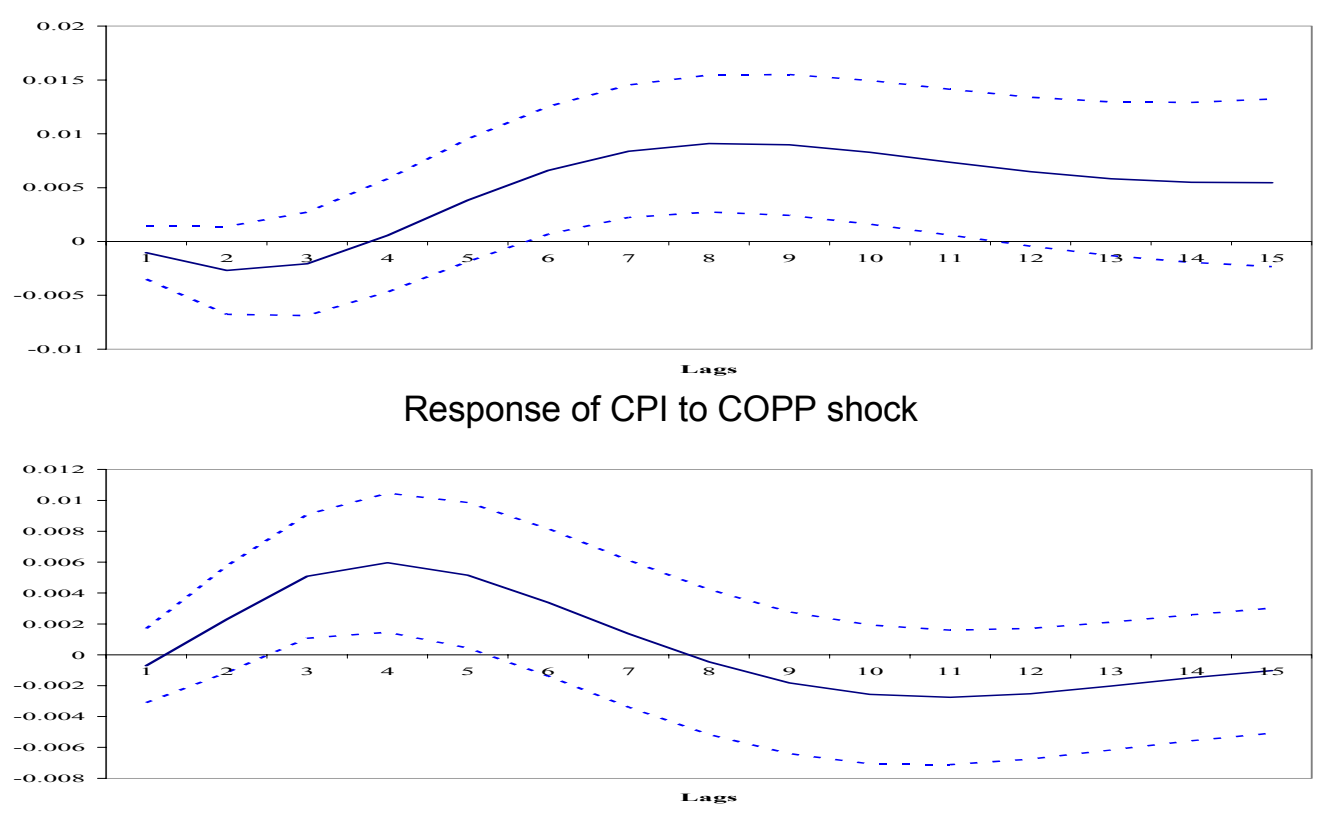

Response of CPI to OIL shock

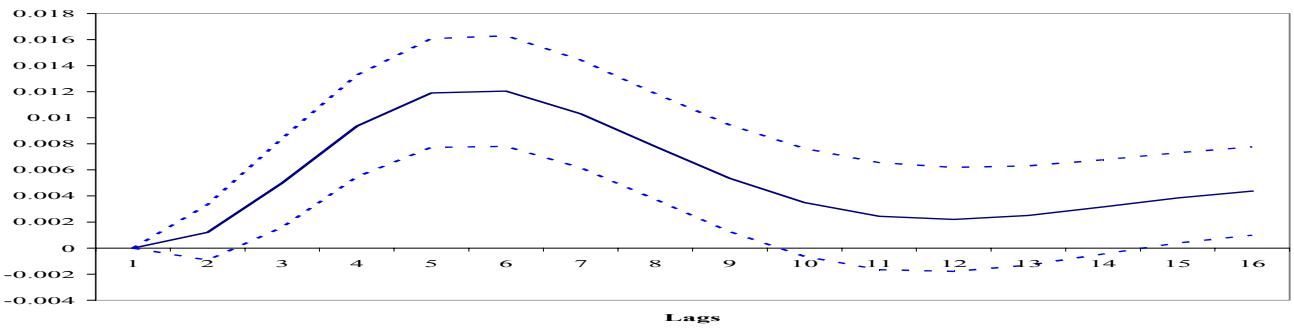

Response of CPI to ER shock>

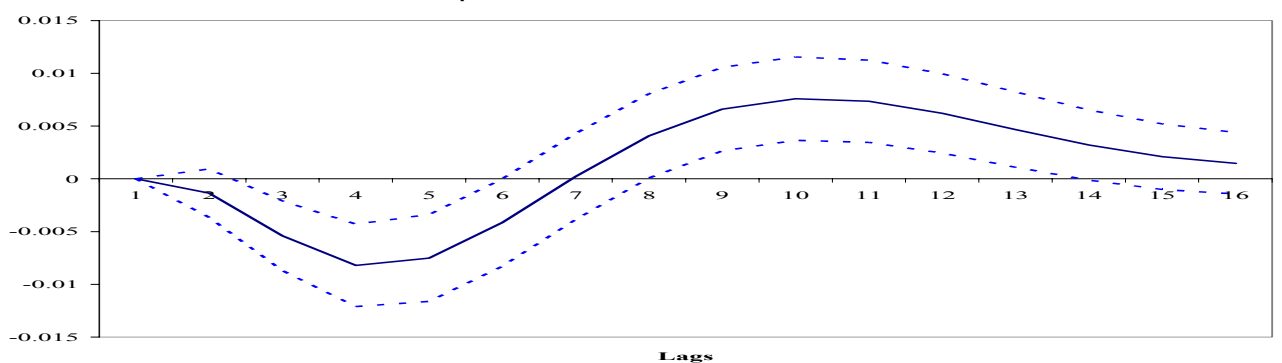

Response of CPI to RM shock

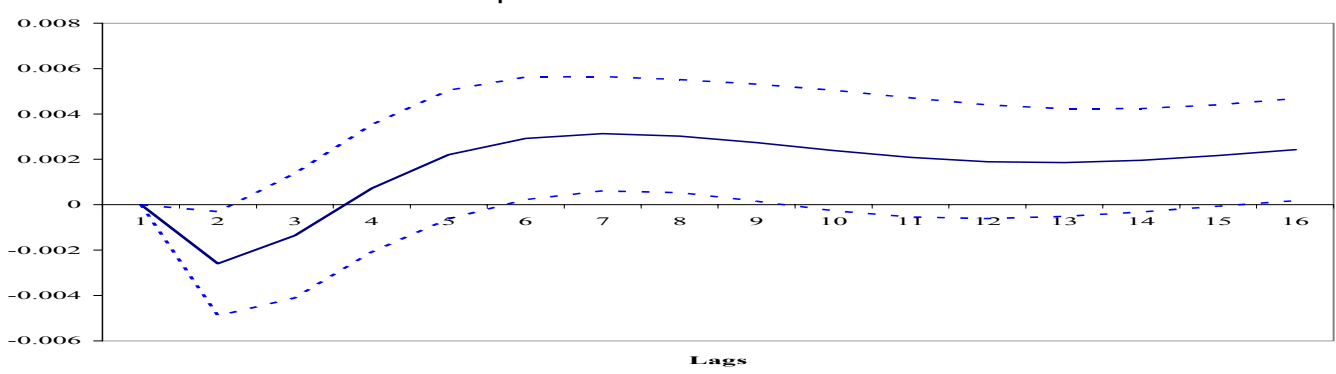

Response of CPI to BM shock 
13. Variance decomposition analysis, indicates that the exchange rate is the predominant factor in explaining the inflation. Changes in the exchange rate explain more than 20 percent of inflation and the impact seems to be persistent. Copper price changes show the importance in CPI changes, as is in the simulation results of the structural model. Reserve money growth also provides explanatory power, with more than 14 percent of the change in inflation related to a reserve money shock one year before.

\begin{tabular}{|ccccccc|}
\hline \multicolumn{7}{|c|}{ Variance Decomposition } \\
\hline Lags & CPI & COPP & OIL & ER & RM & BM \\
\hline 1 & 100.0 & 0.0 & 0.0 & 0.0 & 0.0 & 0.0 \\
2 & 98.2 & 0.2 & 0.1 & 0.2 & 0.3 & 1.0 \\
3 & 92.0 & 0.8 & 0.6 & 2.7 & 3.1 & 0.9 \\
4 & 79.8 & 1.0 & 2.4 & 8.7 & 7.5 & 0.7 \\
6 & 60.6 & 1.5 & 5.1 & 22.1 & 9.5 & 1.2 \\
8 & 51.3 & 6.6 & 5.0 & 26.4 & 8.8 & 1.9 \\
10 & 44.8 & 12.3 & 4.5 & 24.6 & 11.7 & 2.2 \\
12 & 40.8 & 15.6 & 4.6 & 22.7 & 14.0 & 2.3 \\
14 & 39.3 & 17.3 & 4.7 & 22.0 & 14.3 & 2.4 \\
16 & 38.5 & 18.5 & 4.5 & 22.0 & 13.8 & 2.6 \\
\hline
\end{tabular}

\section{Concluding Remarks}

14. Inflation in Mongolia is largely affected by food supply constraints, especially meat products, and mineral commodity prices, mostly copper and oil import prices. However, empirical results also indicates that the increase in money supply and changes in the exchange rate have very significant impacts on inflation. In particular, recent low and stable inflation is mostly attributable to the exchange rate appreciation, despite recent commodity price hikes and sharp increases in money supply.

15. Recent inflation trends, however, might not be sustainable unless monetary policy is implemented in a more prudent way to cushion the effects of high mineral prices and the consequent economic boom. In the pursuit of lowering inflation in the medium-term to around 5 percent, as called for under 2007 Monetary Policy Guidelines, the monetary authorities may need to lower reserve money growth further, thereby that of broad money. Inflationary pressures from excessive money supply generally materialize with some time lags and become more difficult to control when the exchange rate starts depreciating, coupled with the impacts of loose fiscal policy, or adverse weather conditions. Accordingly, monetary policy should be pre-emptive to prevent renewed inflation, in line with central bank's ultimate goal. 


\section{Annex: Estimation Results of the Structural Model}

$$
\begin{aligned}
\log (\mathrm{CPI})= & -1.591+0.011 \log (\mathrm{BM})+0.017 \log (\mathrm{OIL}(-1))+0.051 \log (\mathrm{COPP}) \\
& (-2.27)(0.26) \quad(0.31) \\
& +0.437 \log (\mathrm{ER})+0.561 \log (\mathrm{CPI}(-1))
\end{aligned}
$$

adjusted $\mathrm{R}^{2}=0.983$, D.W. $=1.98$

$$
\begin{aligned}
& \log (\mathrm{BM})=0.902+0.175 \log (\mathrm{RM})-0.232 \log (\mathrm{ER})+0.895 \log (\mathrm{BM}(-1))
\end{aligned}
$$

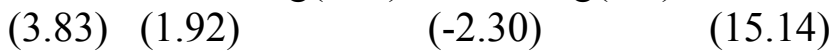

$$
\begin{aligned}
& +0.065 \text { DUM2 } \\
& \text { (2.39) } \\
& \text { adjusted } \mathrm{R}^{2}=0.993, \text { D.W. }=1.20 \\
& \log (\mathrm{RM})=0.004+0.001 \log (1+\mathrm{LR} / 100)+0.998 \log (\mathrm{RM}(-1))+0.151 \text { DUM2 } \\
& \text { (0.01) (1.85) (30.62) (3.86) } \\
& \text { adjusted } \mathrm{R}^{2}=0.984, \text { D.W. }=2.27 \\
& \log (\mathrm{ER})=1.049-0.101 \log (\mathrm{EX})+0.143 \log (\mathrm{IM})+0.814 \log (\mathrm{ER}(-1)) \\
& \text { (7.31) (-2.92) (4.06) (32.76) } \\
& \text { adjusted } \mathrm{R}^{2}=0.977, \mathrm{D} . \mathrm{W} .=1.34 \\
& \log (\mathrm{EX})=-9.840+0.383 \log (\mathrm{COPP})+0.447 \log (\mathrm{GOLDP})+0.644 \log (\mathrm{ER}) \\
& (-5.26) \quad(1.74) \\
& -0.243 \log (\mathrm{EX}(-1))+0.301 \mathrm{DUM} 4 \\
& (-1.75) \quad(3.81) \\
& \text { adjusted } \mathrm{R}^{2}=0.674, \mathrm{D} . \mathrm{W} .=1.60 \\
& \log (\mathrm{IM})=-0.142-0.003 \log (\mathrm{OIL})+0.658 \log (\mathrm{EX})+0.378 \log (\mathrm{CPI})+0.059 \log (\mathrm{IM}(-1)) \\
& (-0.30)(-0.02) \quad(5.01) \quad(3.54) \\
& \text { adjusted } \mathrm{R}^{2}=0.732, \mathrm{D} . \mathrm{W} .=1.56
\end{aligned}
$$

* Figures in parenthesis indicate t-values. 


\section{References}

Anderson, J., and, D. A. Citrin, 1995, “The Behavior of Inflation and Velocity," in Policy Experiences and Issues in the Baltic, Russia, and Other Countries of the Former Soviet Union, ed. By D. A. Citrin and A. K. Lahiri, IMF Occasional Paper No. 133 (Washington: International Monetary Fund).

Balke, N., and K. Emery, 1994, "Understanding the Price Puzzle," Economic and Financial Policy Review (4 ${ }^{\text {th }}$ Quarter), Federal Reserve Bank of Dallas.

Barro, R. J., and H. I. Grossman, 1974, "Suppressed Inflation and Supply Multiplier," Review of Economic Studies, Vol. 41, No. 1, pp. 87-104.

Brissmiss, S., and N. Magginas, 2004, "Forward-Looking Information in VAR Models and Price Puzzle," Bank of Greece Working Paper No.10 (February).

De Grauwe, Paul, and Magdalena Polan, 2005, "Is Inflation Always and Everywhere a Monetary Phenomenon?," in Scandinavian Journal of Economics, Vol. 107, No. 2, pp. 239-59.

Khan, S. M., and A. Schimmelpfennig, 2006, "Inflation in Pakistan: Money or Wheat ?," IMF Working Paper 06/132 (Washington: International Monetary Fund).

Kuijs, A., 1999, "Determinants of Inflation, Exchange Rate and Output in Nigeria," IMF Working Paper 99/160.

Liu, O., and O. Adedeji, 2000, "Determinants of Inflation in the Islamic Republic of Iran: A Macroeconomic Analysis,” IMF Working Paper 00/127 (Washington: International Monetary Fund).

Mohanty, M.S. and Marc Klau, 2001, "What determines Inflation in Emerging Market Economies?” Bank for International Settlement Papers No. 8.

Munoz, S., 2005, "High Inflation and Money Demand," in Zimbabwe: Selected Issues and Statistical Appendix, IMF Country Report No. 05/359 (Washington: International Monetary Fund).

Oomes, Nienke and Franziska Ohnsorge, "Money Demand and Inflation in Dollarized Economies: The Case of Russia," IMF Working Paper 05/144 (Washington: International Monetary Fund).

Portes, R., and D. Winter, 1978, “The Demand for Money and For Consumption Goods in Centrally Planned Economies," Review of Economics and Statistics, Vol. 60, No. 1 


\section{LONG-Term Fiscal SuSTAINABILITY IN MONGOLIA ${ }^{7}$}

\section{A. Introduction}

16. Mongolia's public finances are heavily dependent on revenues from the non-oil mineral sector. Overall, revenues from copper, gold and coal mining made up $13 \frac{1}{4}$ percent of total budget revenue in 2005. With further increases in copper prices since 2005 and recent mineral tax increases this ratio is expected to exceed 33 percent in 2006. However, the longer-term outlook is uncertain, as copper prices are expected to decline substantially over the medium term. ${ }^{8}$ Also, prospects for major foreign investment in the mining sector could be affected by recent tax increases and changes in the mining regime. Under these circumstances, revenues from mining sector may remain volatile.

17. The design of a sustainable fiscal policy in view of these developments is challenging and crucial for safeguarding growth prospects and reducing poverty. The authorities need to plan public expenditure taking into consideration revenue shocks arising from the volatility and unpredictability of mineral resource prices. They also need to adopt policies aimed at ensuring the sound management of the country's mineral wealth for future generations. Mongolia faces similar problems as other countries that rely on their nonrenewable resources to finance government spending under the constraint of an uncertain and volatile revenue stream and an exhaustible supply of mineral resources.

18. The mineral resource boom, if effectively managed, could provide Mongolia with an opportunity to address a wide range of the country's economic problems. Mineral revenues can potentially provide large resources to finance essential economic reforms to diversify the economy, strengthen is efficiency and alleviate widespread poverty, while cushioning the most vulnerable against the adverse impacts of future shocks.

\section{International experience shows that resource booms can result in inefficient} ad hoc spending decisions, particularly in countries that lack a clearly formulated medium-term policy framework. Thus, rather than using natural resource revenue to stabilize revenue flows or finance growth-enhancing capital expenditure, some countries have embarked on unsustainable policies based on short-lived natural resource booms. ${ }^{9}$ In some cases, countries borrowed heavily against their anticipated future income (e.g., Venezuela), while in other cases, governments granted large permanent wage increases

\footnotetext{
${ }^{7}$ Prepared by Selim Cakir and Alexander Klemm.

${ }^{8}$ According to the WEO, copper prices are expected to fall steadily from their current (mid-November 2006) level of US\$6,760 per ton to US\$2,400 by 2011.

${ }^{9}$ See for example the analysis in Boccara (1994) covering CFA Franc countries. Some further cases of both good and bad policy responses are discussed in Cuddington (1998).
} 
(e.g., Nigeria) or launched ambitious investment projects with low economic rates of return (e.g., Algeria, Iran, Trinidad and Tobago). ${ }^{10}$

20. In addition to possible policy mismanagement, the volatility of the real effective exchange rate could have negative effects on the economy's competitiveness. Dutch disease - which refers to the loss of competitiveness or deindustrialization of a country's economy - could occur when the natural resource inspired boom raises the value of the domestic currency, making manufactured goods less competitive, increasing imports, and decreasing nonmineral exports. While some real effective exchange rate appreciation is inevitable during a boom, saving some of the income from the booming sector abroad in safe foreign assets or using it to pay off external debt ahead of schedule can help contain the growth in domestic demand and limit the real exchange rate appreciation and its adverse consequences.

21. This paper addresses the mineral wealth management issues faced by Mongolia. Section B describes Mongolia's mining sector and its envisaged development over the medium term. Section $\mathrm{C}$ provides an analysis of Mongolia's mineral wealth and discusses criteria on which the government could rely for deciding on the allocation of the country's mineral wealth between saving and consumption. Section D assesses Mongolia's mediumterm fiscal sustainability. Section E discusses possible institutional responses to fiscal sustainability challenges, including a brief overview of country experiences. Section F concludes.

\section{B. The Mining Sector in Mongolia}

22. Mongolia's mineral output stems mainly from copper, gold and coal mining. This paper illustrates fiscal sustainability challenges mainly in relation to these main natural resources. There are other important minerals, zinc for instance, but for lack of information these were not included in the analysis. This section first reviews the framework for mining taxation and mineral revenues derived, and then assesses expected mining sector developments.

\section{Mining Sector Revenues}

23. In addition to general taxes, firms in the mining sector are liable for royalties and a recently introduced "windfall tax". The royalty is charged at a rate of 5 percent (increased from 2.5 percent in September 2006) on the value of sales of gold and copper. It does not allow for any deduction of costs. The "windfall tax" is levied at a rate of 68 percent on the difference between the actual world copper price (US\$6,936 per ton at end-November 2006) less both smelting costs (estimated at US\$1,580 per ton in 2006) and a fixed amount of US $\$ 2,600$ per ton. For gold it is levied on the difference between actual gold prices (US\$638 per ounce at end-November 2006) and a fixed level of US\$500 per ounce.

\footnotetext{
${ }^{10}$ See Wakeman-Linn et al. (2004)
} 


\section{The current structure of mining taxes could have undesirable effects on}

investment incentives. Since royalties do not allow any cost deductibility and the "windfall tax" only allows the deduction of smelting costs, these taxes could apply not only to rents and profits, but also to costs, which will create inefficiencies. ${ }^{11}$ As a result, some deposits may not be developed, even though they could be exploited profitably, yielding a positive rent. The current tax structure could be also harmful to the mines nearing the end of their lifespan, because in such mines, incremental investment will only take place as long as the return less royalty and "windfall tax" exceeds the marginal cost. Mines may therefore be abandoned prematurely, and since the cost of reopening abandoned mines is prohibitive, some portion of the country's natural resource will remain unexploited. Moreover, the windfall tax on gold has so far proved difficult to enforce, with many gold traders either smuggling their gold out of the country or delaying sales with the expectation that the windfall tax may be repealed.

25. The corporate income tax (CIT) regime for mining sector is the same as in other sectors. It is a split rate system, and from January 1, 2007 its rates are 10 percent on profits up to tog 3 billion and 25 percent on any additional profits. Losses can be carried forward for up to two years and reduce profits by no more than 50 percent. ${ }^{12}$ While the law is the same as in other sectors, its impact on the mining sector may still be different, because of the sector's special characteristics. Specifically, the long delay between the first investment expenditure and the first profit means that the limited loss carry-forward is potentially a greater concern for mining than other firms. ${ }^{13}$ Economies of scale imply that mining firms tend to be larger, which in turn means that they are more likely to fall under the higher of the two tax rates.

\section{In addition, mineral revenues are received for licensing fees, but these are} relatively small. Even though the new Minerals Law adopted in mid-2006 has increased such fees, their contribution to the budget remains negligible. However, licensing fees do have an important role in limiting speculation on licenses. Moreover, the law allows, but does not demand, auctioning of mining sites, which has not occurred yet.

\section{Significant revenues are also received in the form of dividends from Erdenet, a} copper mining company, which is 51 percent owned by the Mongolian state, with the remainder owned by the Russian government. The Mongolian share of the dividend goes into

\footnotetext{
${ }^{11}$ The current basic deduction is high enough to recover all other costs. However, given that it is fixed at $\$ 2,600$ per ton of copper, the unindexed basic deduction could fall short of recovering other operating costs in an inflationary situation.

${ }^{12}$ The tax system that will apply until the end of 2006 has rates that are higher by 5 percentage points, and a much lower threshold for the higher rate. It does not allow any loss-carry forward and disallows deductions of many expenses (e.g., advertising). It does, however, provide for tax holidays for foreign firms undertaking major investment projects. These tax holidays exempt them from CIT for five years and provide an exemption for half of the CIT liabilities for a further five years. These are particularly inefficient in the mining sector, where positive economic rents as a result of the scarcity value of resources are to be earned.

${ }^{13}$ This is slightly mitigated by allowing exploration costs to be amortized over five years.
} 
the budget, usually with a delay of two years after the completion of the accounting year in which they are earned.

28. Total mineral revenues have been very volatile over time. Over the last decade, they have ranged from less than 1 percent to more than 6 percent of nonmineral GDP. CIT revenues from Erdenet have historically accounted for the largest share and most volatility. However, since its introduction in mid 2006, the windfall tax has become the most important source of revenue, and total mineral revenues have reached unprecedented levels.

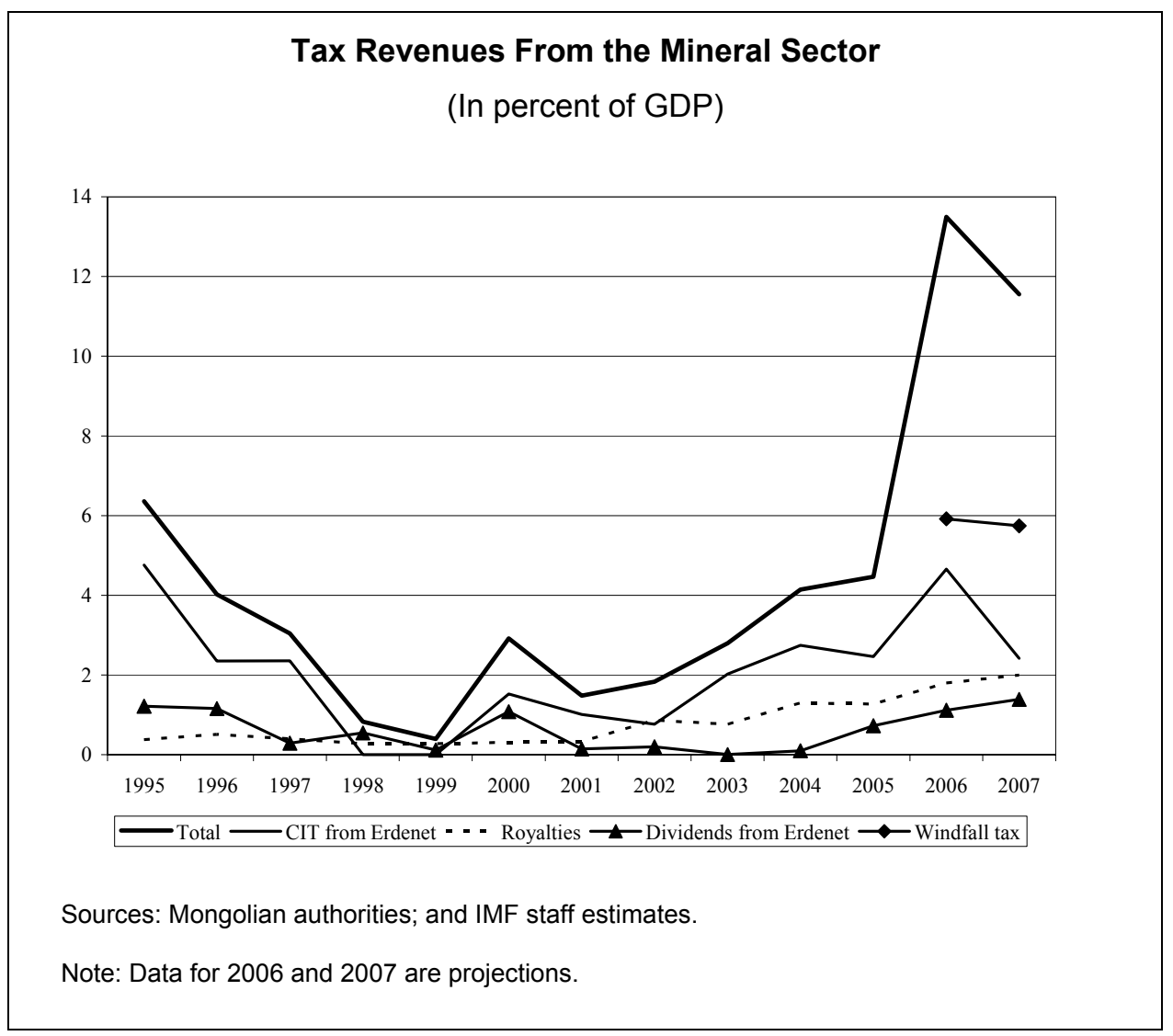

\section{Current and prospective mining operations}

29. The copper sector has long been dominated by the public company Erdenet.

Erdenet has been exploiting a major copper mine since the 1970s, and it expects to be able to continue extraction at the current rate for a further 50 years. Historically, Erdenet has tended to pay out two-thirds of profits as dividends, and this is expected to continue, although it is far from clear whether this is an optimal ratio. Moreover, as stated earlier, Erdenet has tended to pay its dividends with a significant lags, typically reaching the budget two years after the tax year in which they were earned. While a speedier distribution would be useful, it is assumed that this delay continues as it is, although it clearly reduces the value of dividends in present value terms. 
30. Another major firm, Ivanhoe, is expected to start extracting copper and gold from 2009 and to surpass Erdenet as the largest copper producer from around 2011. Making predictions about future mineral revenues is difficult, because (i) the government's equity participation is under consideration, which will affect the government's revenue structure; and (ii) it remains unclear to what extent Ivanhoe will be liable for the windfall tax, as Ivanhoe is considering the construction of an on-site smelter, which apparently would exempt the company from being liable for the windfall tax, as it applies only to raw copper ores.

31. The gold sector is more diverse with over $\mathbf{1 0 0}$ companies of different sizes. So far gold companies have not paid CIT as they have been covered by tax holidays or other exemptions. Although Boroogold, the largest, is exempt from the windfall tax, it recently agreed to pay the government an additional US\$10 million this year and to begin paying CIT at the full income tax rate from 2007. Boroogold is also currently negotiating a new investment contract for the development of another deposit. Given the imminent abolition of tax holidays, it is likely to have to pay taxes on profits from the new deposit from the beginning, although details of the contract are not known yet.

\section{Mineral reserves}

32. Mongolia has considerable mineral resources, although estimates of proven and potential resources are subject to large uncertainties. Overall, only 15 percent of the total area has been geographically mapped (USGS 2004), and therefore, estimates are very approximate. The table below provides an overview of operating and prospective mines in Mongolia. The Baganuur site is particularly noteworthy, as its estimated reserves include 6 billion tons of coal and 2.4 billion tons of coke.

\begin{tabular}{|c|c|c|c|}
\hline \multicolumn{4}{|c|}{ Largest Operating and Prospective Mines in Mongolia } \\
\hline Name of Deposit & Type of Mineral Resource & Location & Operational \\
\hline Erdenet & Copper, molybdenum & Erdenet city & yes \\
\hline Oyu Tolgoi & Copper, gold & Umnu-Govi aimag & No \\
\hline Tavan Tolgoi & Coking coal & Umnu-Govi aimag & Partially \\
\hline Burenkhaan & Phosphate & Huvsgul aimag & No \\
\hline Tumurtei & Iron & Selenge aimag & No \\
\hline Tumurtiin Ovoo & Zinc & Suchbaatar aimag & Yes \\
\hline Asgat & Silver & Bayan-Ulgii aimag & No \\
\hline Tsagaan Suvraga & Copper & Dorno-Govi aimag & No \\
\hline Bor Undur & Fluorspar & Khentii aimag & Yes \\
\hline Boroo & Gold & Selenge aimag & Yes \\
\hline Gatsuurt & Gold & Selenge aimag & No \\
\hline Hailaast & Gold & Tuv aimag & Yes \\
\hline Baganuur & Coal & Baganuur city & Yes \\
\hline
\end{tabular}




\title{
C. Mongolia's Mineral Wealth
}

33. When a significant share of government revenue is derived from the exploitation of nonrenewable resources, the finite nature of the resource needs to be considered. This is important to ensure fiscal sustainability as well as intergenerational equity. Considerations of long-run fiscal sustainability would generally imply saving a portion of today's nonrenewable resource revenue and setting normative limits on the nonresource fiscal deficit. This approach would both stabilize usable revenue and provide for the accumulation of financial resources that make up for the depletion of the natural resource, thereby helping to implement fiscal policies that are set within a longer-term framework.

\section{Estimating Mongolia's mineral wealth is the first step in assessing long-term}

fiscal sustainability. The value of wealth is derived, among other things, from the amount of total proven mineral reserves, the production profile, extraction costs, the tax system, the assumptions on the long-term world mineral prices, the discount rate, and the real rate of return on financial assets. ${ }^{14}$ The estimates of the net present value (NPV) of Mongolia's mineral revenues for 2006-50 provided in this paper are based on the assumptions detailed in Box II.1. ${ }^{15}$

\section{Box II.1. Mongolia: Assumptions Underlying Mineral Wealth Calculations}

\author{
Total Production: \\ Copper \\ Erdenet: 23747000 tons. \\ Ivanhoe : 41549000 tons. $^{1}$ \\ Gold \\ Ivanhoe: $10336000 \mathrm{oz}$. \\ Others: $28215000 \mathrm{oz}$.
}

Prices: Copper and gold price estimates are based on World Economic Outlook (WEO) projections. Beyond the seven year-period of forecasts provided by the WEO, it is assumed that copper and gold prices increase in line with world inflation (i.e., 2 percent).

Tax regime: It is assumed that tax regime remains unchanged as described above, except that the windfall tax is assumed to be abolished after 2011. Note that stability agreements/investment contracts mean that even if a tax change takes place, it may have limited effects, as existing operations would not be affected until their arrangements run out.

Discount rate: Nominal rate of return (5 percent); real rate of return on financial investment (3 percent).

${ }^{1}$ Ivanhoe also considers an expanded production plan, which would increase this figure to 50,363,000 tons, see Ivanhoe (2005). We assume that the smaller production plan is followed, and, based on information from Invanhoe, that it is delayed by one year.

\footnotetext{
${ }^{14}$ See Gvenetadze (2006) for a full discussion of calculation of mineral wealth.

${ }^{15}$ Coal is excluded from the calculation of Mongolia's mineral wealth since current revenues from coal mining are very small. However, it should be noted that Mongolia has very large, but as yet unexploited, coal deposits.
} 
35. Estimates of mineral wealth depend on a number of assumptions, but are particularly sensitive to mineral price assumptions. This note therefore considers three different scenarios. The central scenario is based on the best available estimate of copper prices(Box II.1). Two further cases are considered: one in which copper prices stay at the high level of 2006, and one in which they fall back immediately to their long run average of $\$ 2,000$ per ton. Even in the latter case, Mongolia's mineral wealth (the NPV of mineral revenues) would be sizeable at almost twice the nonmineral GDP.

\begin{tabular}{|lccc|}
\hline \multicolumn{4}{|c|}{ Net Present Value of Mongolia's Mineral Revenues (Mineral Wealth) } \\
\hline & $\begin{array}{l}\text { Copper prices return to } \\
\text { long-run level }\end{array}$ & Central case & $\begin{array}{c}\text { Copper prices remain } \\
\text { at current level }\end{array}$ \\
\hline $\begin{array}{l}\text { In millions of U.S. dollars } \\
\text { Percent of nonmineral GDP }\end{array}$ & $2,010.3$ & $3,703.2$ & $11,179.3$ \\
\hline $\begin{array}{l}\text { Source: Authors' calculations. } \\
\text { Notes: The low price case assumes copper prices of } \$ 2,000 \text { per ton until 2011, which is the average price of } \\
\text { the last ten years. The high price case assumes copper prices of } \$ 6,300 \text { until 2011, which is the WEO copper } \\
\text { price assumption for 2006. Beyond 2011 copper prices grow by 2 percent per year in all scenarios. }\end{array}$ \\
\hline
\end{tabular}

\section{Assessing Long-Term Fiscal Sustainability}

\section{The fiscal stance in Mongolia is better assessed in terms of the nonmineral} primary balance. This is a useful indicator for fiscal analysis in mineral rich countries, because it removes most of the cyclicality that is caused by volatile commodity prices and instead reveals the part of the budget that is financed from sustainable sources. ${ }^{16}$ Given the mineral wealth, it is not necessary for the nonmineral primary balance to remain in surplus. The next section will address the question of how large a deficit in the nonmineral primary balance can be sustained permanently by the mineral wealth of the country.

37. The concept of a sustainable nonmineral primary deficit ceiling would introduce an upper bound restriction for the permissible government deficit consistent with the savings objective. It defines what the government can afford to spend over the long term without exhausting its assets, and corresponds to a path of expenditures that can be financed from the use of mineral revenue.

\section{Constant Real Expenditure Approach}

38. A sustainable nonmineral primary deficit ceiling shows how much the government can afford to spend over the long term without exhausting its assets. It corresponds to a constant real expenditure amount that can be financed out of mineral wealth. In order to determine a sustainable constant real expenditure level, the discounted

\footnotetext{
${ }^{16}$ See also Chalk (1998) which argues for the use of a "core" deficit, which also excludes net transfers.
} 
government's net worth should be multiplied by the assumed real rate of return. This represents a fixed annual amount in constant U.S. dollar terms that can be spent indefinitely without ever running out of mineral wealth. Over time the composition of this amount will change from being mainly tax revenues and dividends to interest on the accumulated wealth.

39. The level of constant real expenditure per year during 2006-50 is estimated at \$113.3 million (5.9 percent of projected nonmineral GDP in 2006). This amount will decline gradually relative to nonmineral GDP, as nonmineral sectors expand over time while the fixed annual dollar amount from mineral wealth stays constant indefinitely. By 2050 it declines to 0.6 percent of nonmineral GDP. This is shown in the figure below, which also shows the development of the constant fixed expenditure under a higher and lower copper price scenarios.

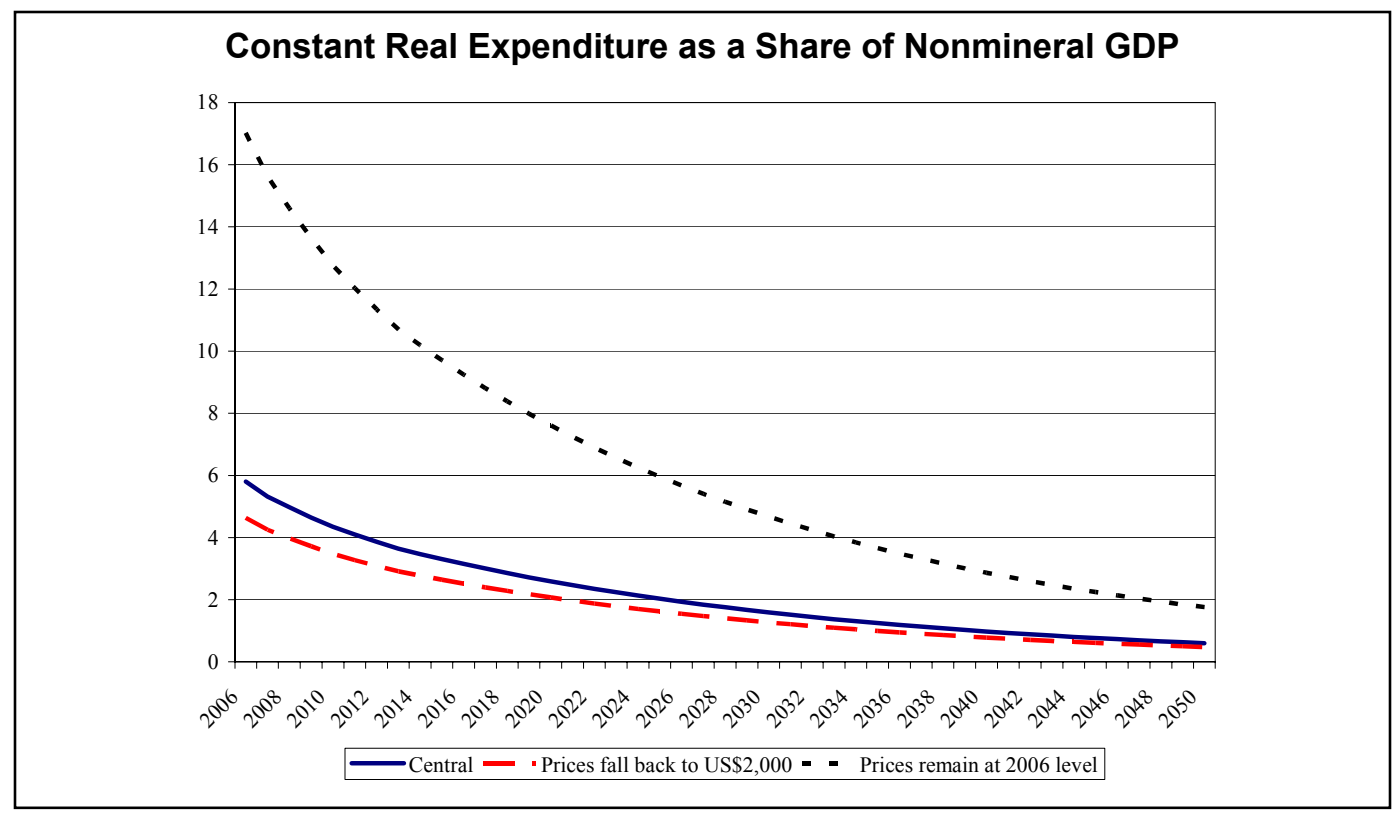

\section{The Current Budgetary Position}

\section{The 2007 budget proposal is budgeted to achieve a nonmineral primary deficit} as a share of nonmineral GDP of 16.3 percent. ${ }^{17}$ Based on the calculations above, this would be sustainable under the most optimistic copper price assumption only. If copper prices drop back as expected under the WEO, however, this would imply that in 2007 more than twice as much of the mineral wealth will be spent as will be possible in the long run. And if prices return to their long-term average, three times the sustainable expenditure would be spent.

\footnotetext{
${ }^{17}$ The staff report and other documents often present the nonmineral primary or overall balance as a share of total rather than nonmineral GDP. This is mainly for convenience, as it allows a direct comparison to the fiscal balances including the mineral sector. However, as total GDP is also strongly affected by mineral prices, the measures defined in terms of the nonmineral GDP are theoretically preferable and should be used if comparing scenarios with different mineral prices.
} 


\section{E. Possible Institutional Arrangements ${ }^{18}$}

41. The analysis above has suggested that mineral revenues in any given year may be different from the share of the mineral wealth that can be sustainably spent. In years of exceptionally high commodity prices or production levels, governments should thus prudently save some of the mineral revenues. In years of low prices, or when production begins to decline, governments may spend more than current revenues. In principle, this is feasible within the normal budgetary framework. There may, however, be some political difficulties in justifying budget surpluses, particularly in low-income countries such as Mongolia. Some countries have, therefore, set up special commodity funds for managing their mineral revenues. The main types of funds are described in the following subsection.

\section{Nonrenewable Resource Funds ${ }^{19}$}

\section{Stabilization funds}

42. The main aim of a stabilization fund is to deal with the volatility of commodity prices. Payments to and withdrawals from the fund can, for example, be triggered by the position of the market price compared to a reference price. By doing so, the fund can help avoid stop-and-go changes in government expenditure, which are likely to hamper efficient government spending. Clearly the process cannot be completely automated, as the long-term reference price is unknown and subject to change. It is thus necessary to adapt the reference price as new information becomes available, particularly, following long periods of deviation between market and reference prices.

\section{Savings funds}

43. The main aim of a savings fund is to save a share of the revenues stemming from exhaustible resources for future generations. This could be either a fixed proportion, or a varying proportion, in which case the fund would combine elements of a savings and stabilization fund. Typically, withdrawals from such a fund are restricted by tight rules that prevent the fund from being used up. Withdrawals could, for example, be limited to the real return achieved on assets in which the fund invests.

\section{Financing funds}

44. A financing fund is the most comprehensive of the three funds, receiving all revenues from mineral resources. Withdrawals are made to finance budget deficits and any remaining funds are invested. A financing fund thus achieves transparency about mineral wealth without restricting fiscal policy by any rigid rules. It also prevents some financially

\footnotetext{
${ }^{18}$ For a more general overview of the operational aspects of fiscal policy in mineral resource-rich countries, see Barnett and Ossowski (2003).

${ }^{19}$ For a fuller discussion of such funds, including international experience, see Fasano (2000) and Davis et al. (2001).
} 
costly behavior that may occur under the previous two funds, such as simultaneous saving and debt issuing. ${ }^{20}$

\section{Fiscal Rules}

45. In addition or instead of savings funds, fiscal rules may be used to limit spending choices of governments. The fiscal rules could, for example, specify that the overall balance may not exceed the real return on mineral wealth, or restrict the nonmineral primary balance to a fixed share of nonmineral GDP. ${ }^{21}$ However, just as there are ways to circumvent restrictions implied by funds, fiscal rules can also be avoided.

\section{Suggestions on a Nonrenewable Resource Fund for Mongolia}

46. Other countries' examples show that success did not lie in the creation of such funds, but rather in fiscal discipline and sound macroeconomic management. In other words, funds are no guarantee that nonrenewable resources will be sustainably managed. This requires prudent fiscal policy, which cannot be guaranteed by a fund. For example, the government could simultaneously accumulate debt to finance deficits and build up large assets inside the fund. However, a well-designed fund could help the government achieve its sound fiscal policy objectives. Some best-practice design principles are given in the following paragraphs.

47. The fund should be coherently integrated into the budget process. This is best achieved by ensuring that the fund operates only as a government account rather than a separate institution. Budget formulation and reporting should focus on the consolidated presentation and expenditure should be executed by the Treasury. The fund should ideally be a "financing" fund, where the fund's balance reflects government saving of its mineral wealth and is presented in the context of all the government's financial assets and liabilities. Because of Mongolia's access to highly concessional debt though, the fund should not finance the part of the overall deficit that can be financed by concessional debt. Instead the fund should invest equivalent amounts in the currency of the debt to reduce risks.

48. Fund assets should be prudently managed, coordinated with other government financing operations and largely invested offshore. Funds can accumulate large amounts of resources and excessive risk-taking would not be appropriate. Holding the assets offshore reduces the impact on the domestic economy, such as through the exchange rate. Funds should also not lend or otherwise encumber their assets.

\footnotetext{
${ }^{20}$ For a description of the Norwegian financing fund, which is considered international best practice, see Skancke (2003).

${ }^{21}$ Recent examples of such rules are Sao Tome and Principe (see Segura 2006) and, with an adjustment, TimorLeste (see Box II.2).
} 


\section{Box II.2. The Financing Fund of Timor-Leste ${ }^{1}$}

Timor-Leste recently introduced a non-renewable resource fund to manage its revenues from oil production. The fund is based on the Norwegian fund, which is considered international best practice, with some differences to address the particular situation of the country.

The fund is a financial fund, in that it receives all petroleum revenues and finances the budget deficit. This setup appears particularly appropriate to a new country, with high and immediate investment needs. However, in order to deal with political economy concerns, the concept of "sustainable income" was introduced. Up to that amount, which is defined in law, the fund automatically finances budget deficits. Budget deficits in excess of the sustainable income can still be financed by the fund, but require an additional process of parliamentary consideration and approval.

The fund thus tries to combine two conflicting goals:

1. Avoiding a systematic overspending of sustainable income from petroleum, and

2. Allowing sufficient flexibility to deal with revenue needs, without the need to circumvent the fund by costly borrowing.

$\overline{{ }^{1} \text { See Daniel et al. (2003). }}$

49. The rules and operations of the fund should be transparent with stringent mechanisms to ensure accountability and prevent misuse. This requires regular and frequent disclosure and reporting on the principles governing the fund, its inflows and outflows, and the allocation and return on assets. The fund's activities should be audited by an independent agency, and investment performance should be periodically evaluated.

50. The current development fund is unlikely to play a useful role in shaping a sustainable fiscal policy. The fund receives just the windfall tax rather than all mineral revenues. If copper prices fall as expected, it will receive only negligible funds from 2008 , when the copper price is expected to fall below the threshold for windfall tax liability, and only the smaller windfall tax revenue from gold would continue. Given the arbitrary thresholds for the windfall tax, it is unlikely that these revenues represent the entire windfall from temporarily high copper prices. Even if they did though, the low savings rate of one third would not achieve much stabilization or intergenerational equity. Finally, the provisions of the fund can easily be circumvented, by using its components to replace other spending or saving, so that its main impact may be on administrative costs.

\section{F. Conclusion}

51. Mongolia will receive substantial revenue from its mineral resources in the coming years. The authorities would benefit from undertaking regular estimates of the country's mineral wealth, which is essential for formulating a medium-term fiscal strategy. The estimates given in this paper provide a first approximation, which will need to be refined as more accurate and complete information becomes available and as new deposits are discovered and developed.

52. Fiscal policy should take the mineral wealth into account when setting targets for the fiscal balances. A rule limiting the nonmineral primary balance to the real return on 
the mineral wealth would ensure both stabilization and intergenerational equity. However, even if the government does not wish to follow this approach fully, either because it doubts the accuracy of the estimates or because it may wish to save less in order to invest in growthenhancing capital, the calculation can still serve as an important input into the fiscal policy considerations. ${ }^{22}$ For practical reasons, the government could initially work with a shorter term horizon and target a nonmineral primary balance that would yield stable debt ratios over the medium term.

\section{This paper finds that the authorities' current fiscal strategy envisaged in the} 2007 budget would be sustainable only under very optimistic copper price assumptions. Any fall in copper prices would put the government on an unsustainable path, with enormous adjustments necessary, if copper prices follow instead the WEO assumptions.

54. Nevertheless, even if mineral prices fall, mineral revenues will remain important and should be managed in a sustainable way. This would imply limiting the nonmineral primary deficit to about 6 percent of nonmineral GDP in addition to what would have been sustainable in a country without any mineral wealth. Any additional funds received from temporary mineral price swings or concessional loans should be saved.

55. While not indispensable, a special fund could help achieve a sustainable fiscal policy. Based on international experience, a fund of the financing variety would be ideal, though with the particular feature for Mongolia, the fund should not crowd out concessional loans. The detailed design of the fund is important for its success; however, some features of the existing development fund raise doubts that it can play a useful role.

\footnotetext{
${ }^{22}$ For a theoretical argument that countries whose initial capital stock is small should spend a larger share of the mineral revenues upfront, see Takizawa et al. (2004).
} 


\section{References}

Barnett, S., and R. Ossowski, 2003, “Operational Aspects of Fiscal Policy in Oil-Producing Countries” in: Davis et al., pp. 45-81.

Boccara, B., 1994, "Why Higher Fiscal Spending Persists When a Boom in Primary Commodities Ends,” World Bank Policy Research Working Paper 1295.

Chalk, N., 1998, "Fiscal Sustainability with Non-Renewable Resources," IMF Working Paper 98/26 (Washington: International Monetary Fund)..

Cuddington, J., 1998, "Fiscal Policy in Commodity-Exporting LDCs," Policy Planning and Research Working Paper 33 (Washington: The World Bank).

Daniel, J., R. Krever, K. Ogata, B. Taplin, and D. Webber, 2003, “Democratic Republic of Timor-Leste: Establishing the Permanent Fund for East Timor," IMF Technical Assistance Report, (Washington: International Monetary Fund).

Davis, J.M., R. Ossowski, J. Daniel, and S. Barnett, 2001, "Stabilization and Savings Funds for Nonrenewable Resources," Occasional Paper 205 (Washington: International Monetary Fund).

Davis, J.M., R. Ossowski, and A. Fedelino (eds.), 2003, Fiscal Policy Implementation in Oil Producing Countries, (Washington: International Monetary Fund).

Fasano, U., 2000, "Review of the Experience with Oil Stabilization and Savings Funds in Selected Countries,” IMF Working Paper 00/112 (Washington: International Monetary Fund).

Gvenetadze, K., 2006 "Long-Term Fiscal Sustainability in Azerbaijan," in Selected Issues for the 2005 Article IV with Azerbaijan, (Washington: International Monetary Fund).

Ivanhoe Mines, 2005 “Oyu Tolgoi Project, Mongolia - Integrated Development Plan, Executive Summary".

Segura, A., 2006 "Management of Oil Wealth Under the Permanent Income Hypothesis: The Case of Sao Tome and Principe," IMF Working Paper 06/183 (Washington: International Monetary Fund)..

Skancke, M., 2003 "Fiscal Policy and Petroleum Fund Management in Norway," in: Davis et al., pp. 316-338.

USGS, 2004,: “The Mineral Industry of Mongolia,” in: U.S. Geological Survey, Yearbook. 
Takizawa, H., E. H. Gardner, and K. Ueda, 2004, “Are Developing Countries Better Off Spending their Oil Wealth Upfront?”, IMF Working Paper 04/141 (Washington: International Monetary Fund.

Wakeman-Linn, J., C. Aturupane, S. Danninger, K. Gvenetadze, N. Hobdari, and E. Le Borgne, 2004, "Managing Oil Wealth: The Case of Azerbaijan," (Washington: International Monetary Fund). 


\section{The BANK OF MONGOLIA's GOLd OPERATIONS ${ }^{23}$}

\section{A. Introduction}

56. The Bank of Mongolia (BOM) has been engaged in gold operations since the early 1990s. The main purpose of its engagement is to provide liquidity to market participants and economies of scale. Until 2001, the BOM acted as a monopolistic buyer of gold from local miners, but since 2002, designated commercial banks have also been allowed to purchase gold from local miners. Gold production has leapt fivefold from 1995 to 2005, contributing to a large increase in Mongolia's international reserves.

\section{As the volume of gold production has increased, various questions have been} raised regarding the appropriateness of the $\mathrm{BOM}$ role in gold operations, which is more extensive than in most other gold-producing low-income countries. ${ }^{24}$ One of the main concerns is whether the BOM's gold operations could interfere with the conduct of monetary policy because, without adequate sterilization, gold purchases lead to an increase in reserve money. A second concern relates to governance issues such as the quality and transparency of the BOM's risk management practices. A third concern is that adverse gold price movements could erode the BOM's capital base.

58. This chapter describes the BOM's current involvement in gold operations, assesses their contribution to the economy, and raises some concerns. Despite its beneficial roles, including supporting the gold mining sector, boosting up the economy by promoting gold exports and contributing to accumulate foreign reserves, there have been growing concerns as well. Those primarily relate to the ineffectiveness of monetary policy, inefficiency of foreign reserves management, and weakening of central bank governance. The chapter concludes with policy recommendations to address the concerns.

\section{B. The BOM's Involvement in the Domestic Gold Market}

\section{The BOM started its gold market operations under the first "Gold Program" in}

1991. At that time, Mongolia's economy was at a relatively early stage of transition from a planned to a market economy. While the exploitation of natural resources (e.g., copper and gold) was seen as an important engine to growth, the domestic gold market was underdeveloped, with few participants on both the supply and demand sides. Local gold mining companies did not have sufficient capital to expand gold exploration, and commercial banks did not have the capacity to provide adequate intermediation in the gold market. As a result, the BOM was instructed by the government to step in to support the gold mining industry.

\footnotetext{
${ }^{23}$ Prepared by SeungHo Lee and Yinqiu Lu.

${ }^{24}$ For example, since 1997, South African gold miners have been allowed to sell their output independently of the South African Reserve Bank (SARB), provided that the SARB has granted the necessary exemption from relevant Exchange Control Regulations. This led to a gradual but dramatic decline in the central bank's involvement in the gold market.
} 
60. The BOM further stepped up its involvement in gold operations under the socalled "Gold 2000 Program." Under the program, the BOM's role in gold trading was upgraded, granting the BOM a buyer's monopoly of gold from miners. Furthermore, the BOM started providing gold mining companies with financial support (e.g., credit guarantees) to facilitate their access to working capital. As a result, the number of gold mining companies doubled from the mid-1990s, to reach 133 at end-2005, while gold output increased sharply.

\section{The BOM's monopoly ended on January 1, 2002, when the gold market was} deregulated under the amended Central Bank Law. The main purpose of the deregulation was to reduce the BOM's involvement in quasi-commercial activities and to promote competition in the gold market. Thereafter, commercial banks began purchasing gold and building their institutional capacity. As a result, their share in gold trading has increased gradually. It reached more than half of total gold purchases in 2005, for the first time ever, although it declined again in 2006 after the implementation of the new windfall tax in mid-2006, which has also affected the BOM's gold purchases, but to a lesser extent. Despite the liberalization of the market, however, commercial banks continue to resell most of their gold purchases to the BOM due to their liquidity constraints, small scale of operations, and lack of risk management capacity. ${ }^{25}$

\begin{tabular}{|cccccc|}
\hline \multicolumn{7}{|c|}{ Gold purchased by the BOM and Commercial Banks } \\
\hline \multicolumn{7}{c}{ BOM } & Commercial Banks & Total \\
\hline & $($ In kg) & $($ In percent) & $($ In kg) & (In percent) & $($ In kg) \\
2000 & 12,271 & 100.0 & 0 & 0.0 & 12,271 \\
2001 & 13,660 & 99.3 & 100 & 0.7 & 13,760 \\
2002 & 6,297 & 52.1 & 5,800 & 47.9 & 12,097 \\
2003 & 7,868 & 70.8 & 3,250 & 29.2 & 11,118 \\
2004 & 6,420 & 55.4 & 5,175 & 44.6 & 11,595 \\
2005 & 6,907 & 45.3 & 8,323 & 54.6 & 15,232 \\
2006 (Aug.) & 3,300 & 55.9 & 2,600 & 44.1 & 5,900 \\
\hline Sources: "Mongolian gold market and Mongol Bank” BOM, April, 2006. & & \\
\hline
\end{tabular}

\footnotetext{
${ }^{25}$ Of 16 commercial banks operating in Mongolia as of end-September 2006, TDB, Golomt, Anod, Zoos, Shuudan, and the Savings Bank are most actively involving in the gold trading.
} 
62. The BOM's involvement in the domestic gold market has supported the gold mining sector and changed the composition of Mongolia's exports. Gold exports rose at an average annual growth rate of 40 percent during 1995-2005, reaching 23.8 tons in 2005 compared with merely 4.2 tons in 1995 . Out of 15.2 tons of gold purchased by the $\mathrm{BOM}$ in 2005, 13.8 tons were exported, accounting for 58.0 percent of Mongolia's total gold exports. ${ }^{26}$ Also buoyed by rising gold prices, the value of total gold exports increased to US\$331.0 million (31.4 percent of total export) in 2005 from US\$51.9 million (10.7 percent of total export) in 1995.

\section{Gold monetization also acts} as a main contributor for the increase in Mongolia's international reserves. It explains about two thirds of the international reserve inflows in 2005, and about half in 2006 up to July. The other sources, such as the loan transfer from abroad and foreign exchange purchases by the BOM are relatively small. As a result, net international reserves (NIR) reached US\$576.6 million at end-October 2006 from

Shares of Main Exports in Total Exports (In percent of total exports)

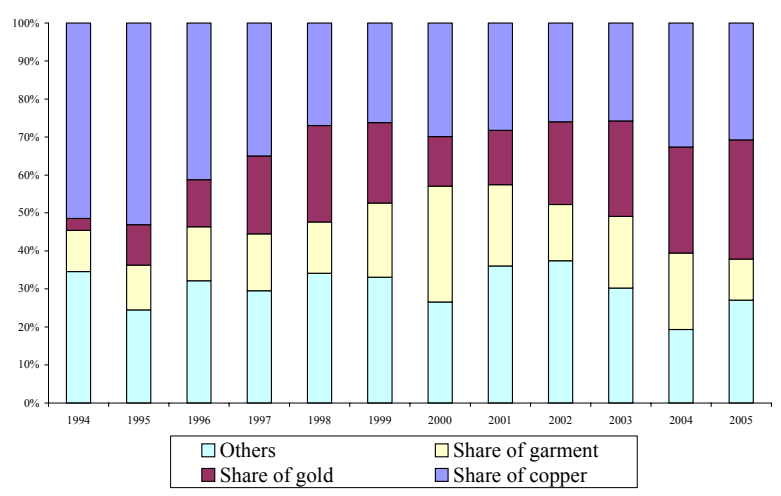
U\$105.4 million at end-1999.

64. The rise in world gold prices since 2001 has ballooned the value of the international reserves, ${ }^{27}$ because Mongolia's Central Bank Law requires that monetary gold be valued at market prices. ${ }^{28}$ In the London market, gold prices jumped to US\$627 per

\footnotetext{
${ }^{26}$ An additional 10 tons was exported by the Boroo Gold Mine Company, 95 percent equity of which is owned by Centerra Gold, a Canadian listed company.

${ }^{27}$ Except in December 2003, when Mongolia made an US\$ 250 million payment to settle pre-1991 debt to Russia.

${ }^{28}$ The Central Bank Law (Article 37) requires that unrealized gains or losses arising from the revaluation of the BOM's international reserve assets and liabilities be reallocated in a revaluation reserve account. In contrast, under the IMF's IAS 21 ("The Effects of Changes in Foreign Exchange Rates") reevaluation gains and losses should be recorded in the income statement, rather than in a reserve account.
} 
troy ounce at the end of the second quarter of 2006 compared with US\$269 at the end of 2000 . As a result, gold valuation has contributed to the increase in the BOM's international reserve holdings. For the same reason, however, a drop in gold prices could deflate the international reserves.

65. To reduce the risks from its gold operations, the BOM has taken

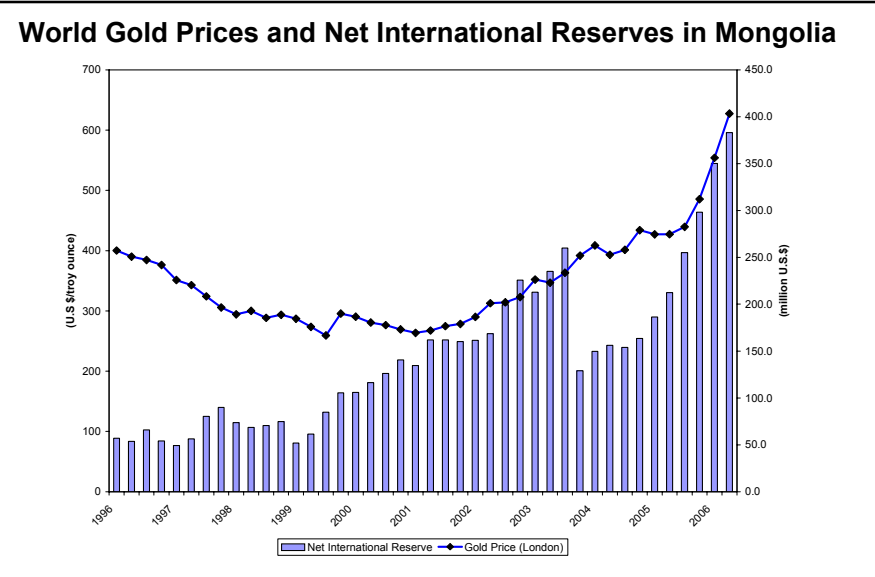

a number of steps. It has amended its internal rules to improve the internal reporting system and strengthened risk management of gold operations. It also introduced detailed operating manuals which include the limits on individual traders' daily open position taking and stoploss. The internal rules also require that a long-term open position be closed before the end of each year.

\section{Main Concerns on BOM's Gold Operations}

66. Despite these measures, the BOM's gold trading activities have given rise to concerns about their potential adverse macroeconomic impacts. The BOM's gold operations may pose significant challenges to the conduct of monetary policy, international reserves management, and central bank governance.

\section{Impact on the Conduct of Monetary Policy}

67. Without sterilization, the

BOM's gold purchases lead to reserve money injection into the economy. In fact, the increase in the reserve money in Mongolia has been largely driven by an increase in NIR. Thus, despite a marked drop in net credit to government, reserve money grew by 19.7 percent in 2005 , stemming from a sharp increase in net foreign assets (82.3 percent from end2004). As of end-August 2006, reserve money increased by 33.3 percent from end-December 2005 , mostly driven by the increase in NIR (70.9 percent). In contrast, during the same period, outstanding CBBs issued declined from tog 125.7 billion to tog 65.3 billion. These developments are clear evidence that sterilization through CBB issuance was not sufficient to mop up the excess liquidity generated through the BOM's gold purchases. 


\section{A regression was used to estimate the degree of sterilization in Mongolia (Box}

III.1). The sterilization coefficien $t^{29}$ is defined as the ratio of the change in CBBs to the change in NIR. The short-term elasticities are estimated at around 60-70 percent and even long-run elasticities are less than 80 percent. This result may indicate that the BOM's gold operations are not sufficiently sterilized. As a result, the effectiveness of monetary policy may be dampened, thereby preventing the BOM from meeting its inflation objective. Notwithstanding some benefits from the BOM's gold operations, the BOM should address more forcefully their negative impact on the monetary policy framework.

69. The BOM's gold operations have a seasonal pattern. Since 2003, most of the BOM's gold purchases were made between the second and the third quarter of the year, while the BOM sold most of the gold it held in the fourth quarter, as required by the internal rule. This pattern partly reflects the strong seasonality of both the mining sector, including gold production, and agriculture. As a result, money supply may expand further in response to the BOM's increasing gold purchases given that it is not closely coordinated with monetary policy operations.

\footnotetext{
${ }^{29}$ It is more generally estimated by analyzing the relationship between changes in net domestic assets and changes in net foreign assets in most countries that rely primarily on open market operations for liquidity control.
} 


\section{Box III.1. Estimation of Sterilization Coefficient}

In order to gauge the degree of sterilization in Mongolia, net issuance of CBBs is estimated through several exogenous variables, including net international reserves, consumer price index, lending interest rates, and currency in circulation. The coefficient of NIR is a proxy of the sterilization coefficient.

The regression results show that the net issuance of CBBs is positively related, with high statistical significance, to the increase in NIR and the rise of CPI. The elasticity of changes in CBBs with respect to changes in NIR is about $59-67$ percent and less than 80 percent in the long-run $(0.78=0.324 /(1-0.584)$ in equation 2 and $0.70=0.294 /(1-0.579)$ in equation 4$)$.

Frequency : monthly data Sample period : Dec. 1995 - Dec. 2005

Number of observation : $121 \quad$ Estimation method : OLS

\begin{tabular}{|c|c|c|c|c|}
\hline \multicolumn{5}{|c|}{ Dependent Variable: Log (CBB) } \\
\hline Exogenous variables & Equation 1 & Equation 2 & Equation 3 & Equation 4 \\
\hline Constant & $\begin{array}{c}4.556^{*+*} \\
(2.900)\end{array}$ & $\begin{array}{l}1.044 \\
(0.844)\end{array}$ & $\begin{array}{c}0.165 \\
(0.152)\end{array}$ & $\begin{array}{l}0.903 \\
(1.119)\end{array}$ \\
\hline $\log (N I R)$ & $\begin{array}{l}0.670^{\star \star \star} \\
(5.546)\end{array}$ & $\begin{array}{c}0.324^{\star \star \star} \\
(3.194)\end{array}$ & $\begin{array}{c}0.592^{\star \star \star} \\
(3.768)\end{array}$ & $\begin{array}{c}0.294^{\star *} \\
(2.438)\end{array}$ \\
\hline $\log (\mathrm{CPI})$ & $\begin{array}{l}2.120^{* \star *} \\
(5.900)\end{array}$ & $\begin{array}{l}0.993^{* \star *} \\
(3.263)\end{array}$ & $\begin{array}{l}2.349^{* \star *} \\
(5.112)\end{array}$ & $\begin{array}{c}0.855^{* *} \\
(2.248)\end{array}$ \\
\hline LR & $\begin{array}{l}-0.009^{* *} \\
(-2.480)\end{array}$ & $\begin{array}{l}0.0003^{* \star *} \\
(0.107)\end{array}$ & - & - \\
\hline $\log (\mathrm{CIC})$ & - & - & $\begin{array}{l}0.296 \\
(1.108)\end{array}$ & $\begin{array}{l}0.089 \\
(0.445)\end{array}$ \\
\hline $\log (C B B)_{-1}$ & - & $\begin{array}{l}0.584^{* * *} \\
(8.637)\end{array}$ & - & $\begin{array}{l}0.579^{* * *} \\
(8.835)\end{array}$ \\
\hline $\begin{array}{c}\text { Adjusted R-squared } \\
\text { D.W. }\end{array}$ & $\begin{array}{c}0.880 \\
0.78\end{array}$ & $\begin{array}{l}0.924 \\
2.30\end{array}$ & $\begin{array}{c}0.875 \\
0.80\end{array}$ & $\begin{array}{l}0.925 \\
2.28\end{array}$ \\
\hline \multicolumn{5}{|c|}{$\begin{array}{l}1 /{ }^{* *} \text { and }{ }^{* *} \text { indicate } 1 \text { percent and } 5 \text { percent significance levels. } \\
\text { 2/ Numbers in parentheses indicate t-values. } \\
\text { 3/ CBB: outstanding of Central Bank Bills issued; NIR: net international reserves; } \\
\text { CPI: consumer price index; LR: lending interest rates; CIC: currency in circulation }\end{array}$} \\
\hline
\end{tabular}




\section{International Reserve Management}

70. The share of gold in Mongolia's total international reserves has been large but volatile. The share peaked at 57.4 percent at end-November 2004 before declining to zero in December 2005.

Subsequently, it rose to 44.5 percent at the end-June 2006 but fell again to 25.3 percent at the end-September. Mongolia's share of total international reserves held in the form of gold is large compared with other gold producing countries. In the case of South Africa, for example, the share of gold in total international reserves stood at around 10 percent at end-September 2006.

\section{The BOM's gold operations may hamper the management of international} reserves. The BOM has relied on derivative instruments (e.g., forwards and options) to hedge the gold price risk. However, the BOM has used derivatives to take positions in the market for the purpose of maximizing returns on foreign reserve assets. Such activities can expose the BOM to significant risks that could damage the BOM's reputation and credibility. ${ }^{30}$ Therefore, it is crucial that the BOM's risk exposure in connection with its gold operations be monitored continuously through reliable information, efficient reporting system, and an independent audit function.

72. Holding international reserves has both costs and benefits. Because the BOM has to pay interests on CBBs used to sterilize international reserves, domestic interest rates or GDP growth rates could serve as proxies for assessing the cost of holding international reserves. Conversely, adjustment costs from external imbalances could be viewed as a gain from holding international reserves, because any international reserve shortage may require strong and costly policy adjustment to phase out the imbalances. Propensity to import could be a proxy for estimating the benefits from holding international reserves, since the higher the propensity to import, the more likely is the emergence of external imbalances.

International interest rates are also considered as a benchmark of the return from holding international reserves because most foreign reserves in central banks are invested in safe assets abroad with interest income. For this reason, the interest rate differential, instead of domestic interest rate, is regarded as a net cost of holding international reserves.

\footnotetext{
${ }^{30}$ The main issues of transparency in the context central bank governance and accountability in reserve management are addressed in the IMF's 'Code of Good Practices on Transparency in Monetary and Financial Policies: Declaration of Principles in September, 1999 (MFP transparency Code).
} 
73. Given the sizeable gold holdings, there is a need to assess the cost of holding international reserves in Mongolia. Although not as large as it was in the past, the spread between domestic and international interest rates spread remains very high. In contrast, the propensity to import, a proxy for the benefits from holding international reserves has been decreasing rapidly. This may imply that there is diminishing needs for the BOM to build up excessive international reserves at high costs.

\begin{tabular}{|c|c|c|c|c|c|c|c|}
\hline \multicolumn{8}{|c|}{ Interest Rate Spread and Average Propensity to Import } \\
\hline & 2000 & 2001 & 2002 & 2003 & 2004 & 2005 & 2006 \\
\hline Lending Rate $(A){ }^{1 /}$ (in percent) & 34.70 & 41.40 & 33.40 & 31.48 & 30.00 & 28.30 & $28.10^{3 /}$ \\
\hline $\operatorname{LIBOR}(B)^{1 / 2 /}$ & 6.48 & 1.87 & 1.38 & 1.13 & 2.47 & 4.47 & $5.38^{3 /}$ \\
\hline Spread (A-B) & 28.22 & 39.53 & 32.02 & 30.35 & 27.53 & 23.83 & 22.72 \\
\hline Import (C) (in millions of US\$) & 676.0 & 693.1 & 752.8 & 826.6 & $1,021.2$ & $1,223.6$ & $1,532.1^{4 /}$ \\
\hline Nominal GDP (D) (in millions of US\$) & 947.5 & $1,018.1$ & $1,121.1$ & $1,285.3$ & $1,625.2$ & $2,065.3$ & $2,787.9^{4 /}$ \\
\hline Propensity to Import (C/D) & 71.3 & 68.1 & 69.1 & 64.3 & 62.8 & 59.2 & 55.0 \\
\hline $\begin{array}{l}\text { 1/ End-year. } \\
\text { 2/ 3-months on U.S. dollar deposits. } \\
\text { 3/ End-August. } \\
\text { 4/ IMF Staff estimates. }\end{array}$ & & & & & & & \\
\hline
\end{tabular}

\section{BOM's Income Statements}

74. The BOM's gold operations affect its income statement in three ways. These include: (i) the profit or loss from the spot trading of monetary and nonmonetary gold; (ii) revaluation and (iii) profit or loss from derivative transactions. The income from gold spot trading itself has two parts. The first part is the fees that the BOM charges on domestic gold sellers for gold insurance, shipping, and refining cost. The second component on spot transactions arises when the BOM sells or buys gold from the over-the-counter (OTC) market, thereby generating income and expenses.

75. The bulk of income and expenses from gold operations comes from revaluation reflecting changes in both gold prices and the exchange rate. Whenever the BOM has a long position on nonmonetary gold or monetary gold, the increase in gold prices yields profits. Likewise, when the togrog depreciates against US\$, the gold value denominated in togrog increases and profits arise. Gold revaluation was the main contributor to the BOM's income surplus in 2005 . 


\begin{tabular}{|c|c|c|c|}
\hline \multicolumn{4}{|c|}{$\begin{array}{c}\text { Income Statement of BOM in } 2005 \\
\text { (In Millions of togrogs) }\end{array}$} \\
\hline & Revenue & Expenses & Net profit \\
\hline Total & 142,385 & 133,055 & 9,330 \\
\hline Gold revenue & 94,820 & 74,194 & 20,626 \\
\hline Trade from gold \& silver & 15,865 & 19,172 & $-3,307$ \\
\hline Revaluation & 76,366 & 52,839 & 23,527 \\
\hline Derivative dealing & 2,589 & 2,183 & 406 \\
\hline Others & 47,565 & 58,861 & $-11,296$ \\
\hline
\end{tabular}

76. Gold derivative transactions also contribute to the BOM's income. The BOM usually sells forward and calls options in the OTC market to hedge its gold position. In 2005, the BOM realized a profit of about US $\$ 2$ million from the option premiums. The BOM also books to market the price movements of forward and options positions. For example, if the price of the option that the BOM wrote increases before maturity, the BOM will record a loss under the item "unrealized derivatives". Upon the expiration of the options, the income or losses recorded under the "unrealized derivatives" item will be moved under the "realized income or losses" item.

\section{The BOM has also at times conducted gold derivative transactions on behalf of} gold mining companies. The BOM levies a fee ${ }^{31}$ for conducting derivatives transactions for mining companies. ${ }^{32}$ The BOM's internal guidelines describe the instruments (spot, forward, and options) used for managing gold operations, the procedures for gold mining companies to submit requests, the BOM's responsibilities, and the penalties imposed on mining companies for late payments. These operations, which are recorded in the BOM's balance sheet as a receivables or payables from the mining companies, could impair the BOM's reputation and may result in a breach of the Central Bank Law.

\section{The BOM's gold operations have been the predominant source of the BOM's} profits and losses. In 2005, total BOM's revenue from gold operations was tog 94.8 billion, accounting for 67 percent of the BOM's total income. Meanwhile, expenses related to gold transactions were tog 74. 2 billion, or about 56 percent of the BOM's expense. The net profit from gold transactions was tog 20.6 billion, largely explaining the BOM's net profit of tog 11.4 billion in 2005.

\footnotetext{
${ }^{31} 5$ percent of the premium for a call option and forward gain, respectively.

${ }^{32}$ Only gold mines with an annual gold production of more than $500 \mathrm{Kg}$ within the last 2 years are eligible for these transactions.
} 
79. The BOM's heavy reliance on gold operations for its income could contain greater cost than the benefit it bears. The benefits could arise from the fact that the gains from gold operations could be used to finance potential fiscal deficits. Nevertheless, a possible dramatic reversal of past gains in the wake of a sharp decline in world gold prices would erode the BOM's capital base. This would damage the BOM's credibility, even threatening financial system stability. In other words, BOM's recapitalization would put further strain on the budget, which could fuel further inflation expectations and would weaken confidence in the togrog. As a result, debt sustainability could deteriorate.

\section{Conclusion}

80. Despite the benefits of the BOM's gold operations, there have also been growing policy concerns. Gold operations injects high powered money into the economy. The sterilization process through issuing CBBs has been insufficient to mop up the liquidity caused by gold purchases, which may mitigate the effectiveness of monetary policy and jeopardize the inflation target aimed at maintaining price stability. It may also give rise to uncertainty and risks regarding the management of international reserves. Moreover, the BOM should consider the high level of domestic interest rates as a cost of holding international reserves. The significant reliance of BOM's income statement on gold trading could also bear more concerns regarding central bank governance. Even though of BOM's profits through gold operations could finance part of the fiscal deficit, the Mongolian authorities should consider the risks in the event of world gold price declines.

\section{A key task ahead for the BOM is how to reduce these risks without adversely affecting the gold mining sector, particularly small producers who do not have the financial expertise or scale of operation necessary to export directly. In view of the still- limited capacity of domestic banks and other market participants, an immediate withdrawal of the BOM from domestic gold market purchases could be counterproductive. However, the BOM should adopt more prudent guidelines for its gold risk exposures, refrain from entering into risky speculative positions in gold and other speculative financial derivatives, and begin preparing a timely exit strategy from the gold market.}




\section{References}

Bhattacharya, H., 2002, "Deregulation of Gold in India: A Case Study in Deregulation of gold Market," World Gold Council in Research Study No. 27.

Cross, J.,2000, “Gold Derivatives - The Market View," Virtual Metal Research \& Consulting Ltd. World Gold Council.

International Monetary Fund, 2003, “Are Foreign Exchange Reserves in Asia Too High?”, World Economic Outlook, Ch. II, pp. 78-92 (Washington).

— , 2004, Guidelines For Foreign Reserve Management, (Washington D.C).

—, 2004, Mongolia Report of the On-Site Safeguard Assessment Mission, unpublished.

Otgondorj, B. 2005, “On Bank of Mongolia's Income Statement,” The Bank of Mongolia, Research Bulletins No. 9.

Reddy, Y. V., March 2002, "Evolving Role of Gold - Recent Trends and Future Direction," at a conference organized by World Gold Council, New Delhi.

Rodrick, D., 2006, “The Social Cost of Foreign Exchange Reserves,” NBER Working Paper No. 11952 (Cambridge, MA: National Bureau of Economic Research).

Song, I., and Vandecan, N., 2006, "Improving Banking Supervision and Reserve Management," Monetary and Capital Market Department, (Washington: International Monetary Fund).

Zhou, X., 2004, "Gold Market Functions to Hedge Against Risks," in Speech at the 2004 London Bullion Market Association Annual Precious Metal Conference. Shanghai.

The Bank of Mongolia, 2005, Annual Report. 


\section{Foreign ExChange Market In MONGOLIA ${ }^{33}$}

82. Mongolia's foreign exchange market is still at an early stage of development. Its main component is the interbank market, where commercial banks trade foreign exchange with each other, as well as with the Bank of Mongolia (BOM), their business clients, and private individuals. The market share of foreign exchange bureaus is fairly small. ${ }^{34}$ Compared with mature interbank markets in developed countries, the bulk of commercial banks' transactions is with their business clients instead of with other commercial banks ${ }^{35}$. Interbank trading, which accounts for most of the activity in mature foreign exchange markets, accounts for less than 20 percent of total transactions in Mongolia. In addition, foreign exchange is only traded at spot prices. Although there are a few forward transactions among commercial banks as part of their own reserve management, there is no real forward market, and commercials banks' ability to hedge foreign exchange risks is limited.

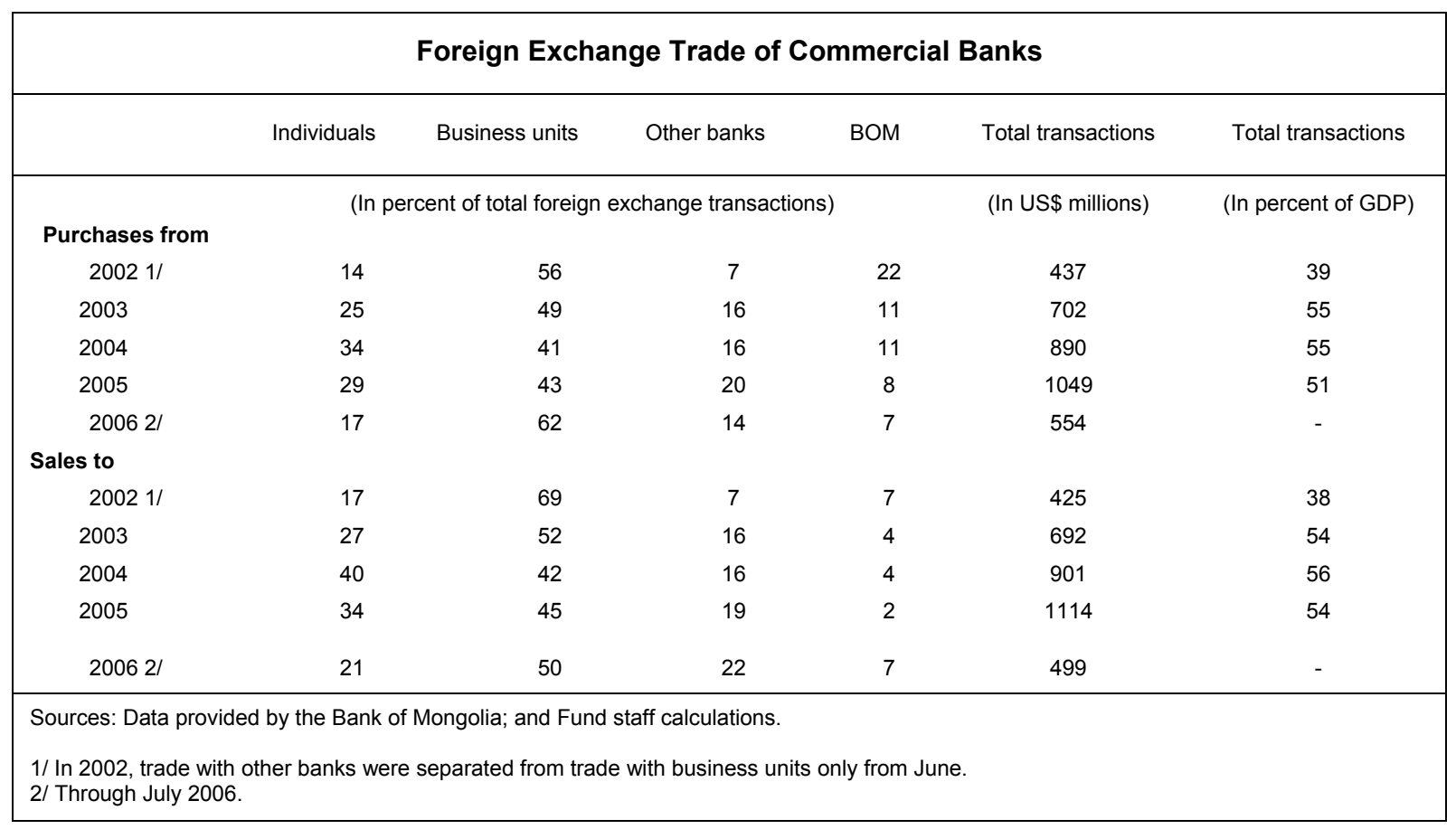

\footnotetext{
${ }^{33}$ Prepared by Yi Wu.

${ }^{34}$ A study conducted a few years ago found that foreign exchange bureaus accounted for 5 percent of total foreign exchange market transactions.

${ }^{35}$ Partly reflecting Mongolia's high degree of trade openness (import and export to GDP ratios were 59 percent and 52 percent in 2005), the shares of foreign currency deposits and loans to total deposits and loans were 43 percent and 44 percent at end-2005.
} 


\section{The BOM sets its daily} midpoint exchange rate based on lagged exchange rates at the interbank market. The midpoint exchange rate of the togrog against the U.S. dollar is set and announced daily in late afternoon, usually calculated as the simple average of the buying and selling rates from the previous day's transactions reported by commercial banks. This rate is then used as the next day's BOM policy rate. Sometimes the midpoint rate is set differently from this rule, especially whenever the BOM decides to keep the BOM rate unchanged, e.g., when the BOM concludes that market fluctuations are temporary. Today's exchange rates from the largest foreign exchange bureaus are also collected (dubbed "curb rates") as a reference for setting the midpoint rate. The BOM rate broadly follows the interbank rate with a lag.

\section{The midpoint rate is only used in government transactions and customs} valuation, for accounting and taxation purposes. All other transactions, including sales of retained foreign exchange by public sector enterprises, take place through the interbank market. Exchange rates for other convertible currencies are calculated on the basis of the cross rates against the dollar in international markets.

\section{Interventions are officially limited to smoothing high-frequency fluctuations in}

the foreign exchange market, using the U.S. dollar as the principal intervention currency. Because the BOM can accumulate foreign reserve through its gold operations, there is usually no need for the BOM to purchase foreign exchange from the market for that purpose. Indeed, the BOM has been a net seller of foreign exchange in the interbank market.

\begin{tabular}{|lrrrr|}
\hline \multicolumn{5}{|c|}{$\begin{array}{l}\text { BOM's Gold Purchases and Reserve Accumulation } \\
\text { (In millions USS\$) }\end{array}$} \\
\hline & 2002 & 2003 & 2004 & 2005 \\
\hline & 118 & 158 & 137 & 210 \\
BOM gold purchase & 66 & -97 & 37 & 131 \\
Increase in net international reserves & & & & \\
& & & & \\
\hline Source: Data provided by the Bank of Mongolia.
\end{tabular}

86. The BOM has deliberately avoided intervening in the interbank market in recent years. Although there were episodes of deliberate intervention in the past, in recent years the BOM's interventions, which are not sterilized, have been limited to fulfilling 
requests from commercial banks. The BOM also claims that no interventions for smoothing purposes were made, probably reflecting broad stability of the exchange rate, with the togrog only depreciating by 6 percent against the U.S. dollar during 2001-end-July 2006 and the real effective exchange rate appreciating by 7 percent over the same period.

\section{The BOM's buying and selling rates are set at five togrogs below and above the} midpoint rate. This trading margin of ten togrogs is high compared with those of the commercial banks, which are usually four togrogs or less for transactions with business clients. The BOM has deliberately set a large margin to reduce commercial banks' incentives to trade foreign exchange with the BOM. Occasionally, a different margin (e.g., eight togrogs) was applied.

\section{The BOM's market share in Mongolia's foreign exchange market has declined} significantly in recent years. The BOM's high margins reduced arbitrage opportunities arising from the difference between the BOM's rates and market rates. Commercial banks generally only approach the BOM when they are under liquidity constraints, which has led to a decline in the BOM's market share in recent years. While in 2002 commercial banks purchased 22 percent of their foreign exchange needs from the BOM, this share declined to 8 percent in 2005 . Increased foreign exchange inflows in recent years have eased commercial banks' liquidity constraints, as a result banks rely on the BOM to a lesser extent to meet

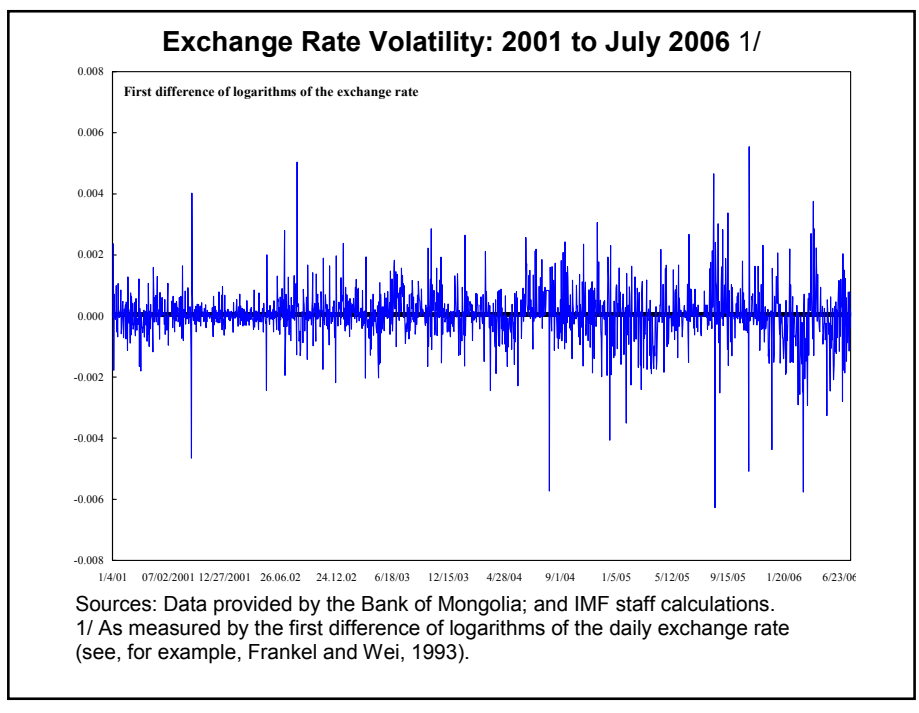
their liquidity requirements. Exchange rate volatility has increased slightly since 2004.

\begin{tabular}{|lllllr|}
\hline \multicolumn{7}{|c|}{ Exchange Rate Volatility, 2001 to July 2006} \\
\hline 2001 & 2002 & 2003 & 2004 & 2005 \\
\hline
\end{tabular}

89. The seasonality of the togrog exchange rate against the U.S. dollar appears to have dampened somewhat recently. The togrog usually appreciates in the first half of the year, in response to sales of raw materials (e.g., cashmere, skin and hides) in the spring and 
inflows of financing for mining operations (usually in the second quarter), and depreciates in the second half of the year, as mining companies pay off loans toward the end of the year. ${ }^{36}$ With the increase in foreign exchange inflows in recent years, in particular FDI and tourism receipts (which peaks after June), this pattern seems to have dampened somewhat recently, as the depreciation of togrog did not pick up until August in 2005, and the togrog's appreciation during 2006 has lasted longer.

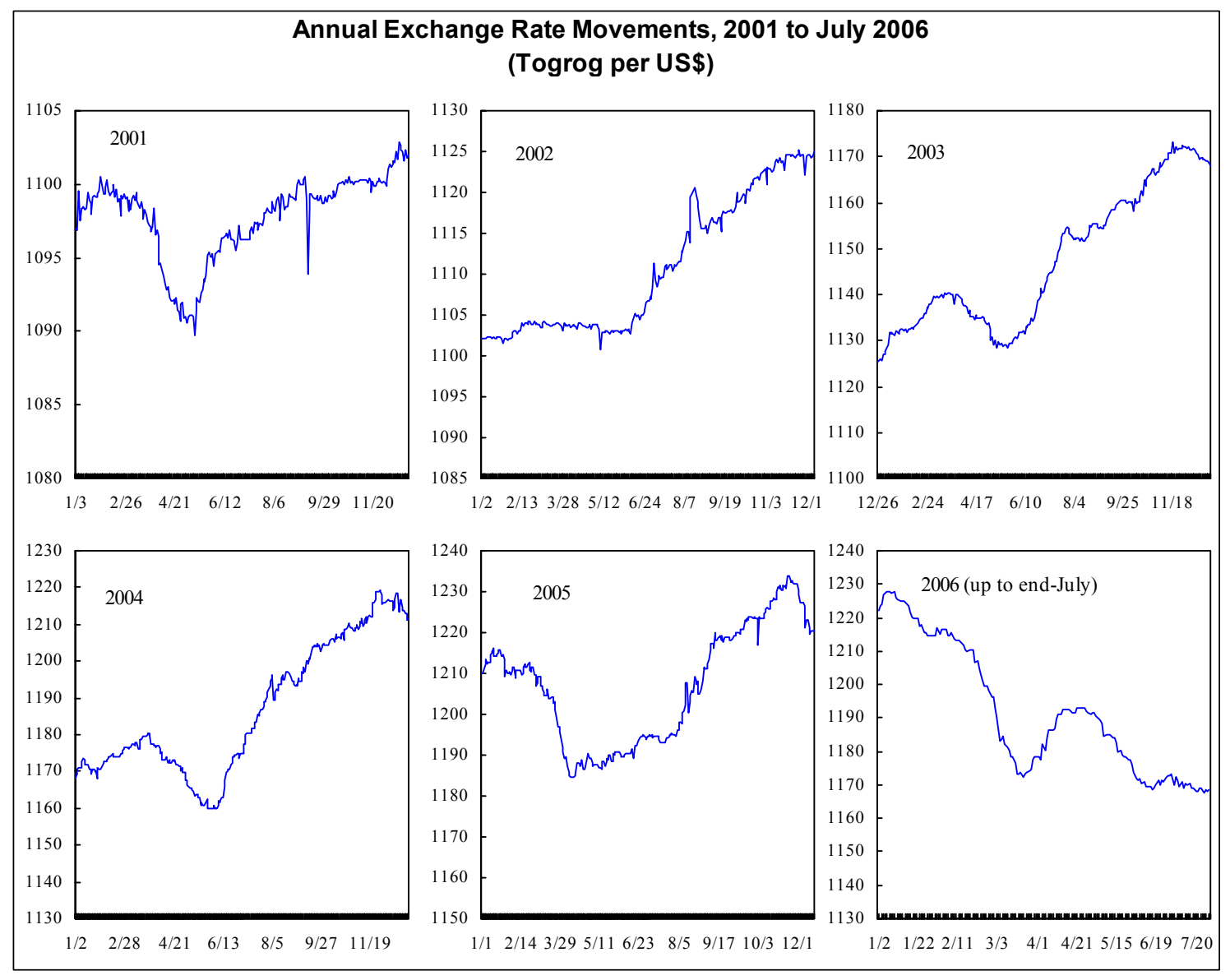

90. The BOM may reject foreign exchange requests from commercial banks.

Occasionally, the BOM declines banks' requests, if it considers they are for arbitrage profits. ${ }^{37}$ The BOM may also refuse to sell foreign exchange to banks if the BOM considers the level of its international reserves to be low. No explanations are given to commercial banks, however, when their requests for foreign exchange are declined.

\footnotetext{
${ }^{36}$ Nevertheless, during 2001-05 the togrog consistently depreciated against the dollar toward the end of the year.

${ }^{37}$ From September 2005 to July 2006, this allegedly happened in three days.
} 
91. The impact of the BOM's intervention on the market rate is limited. The BOM's interventions are atypical of central banks' interventions, whereby the central banks buy or sell foreign exchange in order to affect the exchange rate level. Nevertheless, the impact could still be significant, given that these interventions are relatively large. The BOM intervened in the foreign exchange market in 2005 with eight purchases of U.S. dollars totaling \$27 million and 74 sales totaling $\$ 81$ million. However, in general the exchange rate did not move in the anticipated direction (in the near future). This reflects the passive nature

BOM's Intervention in the Interbank Market and Exchange Rate Movements in $20051 /$ (Togrog per US\$)

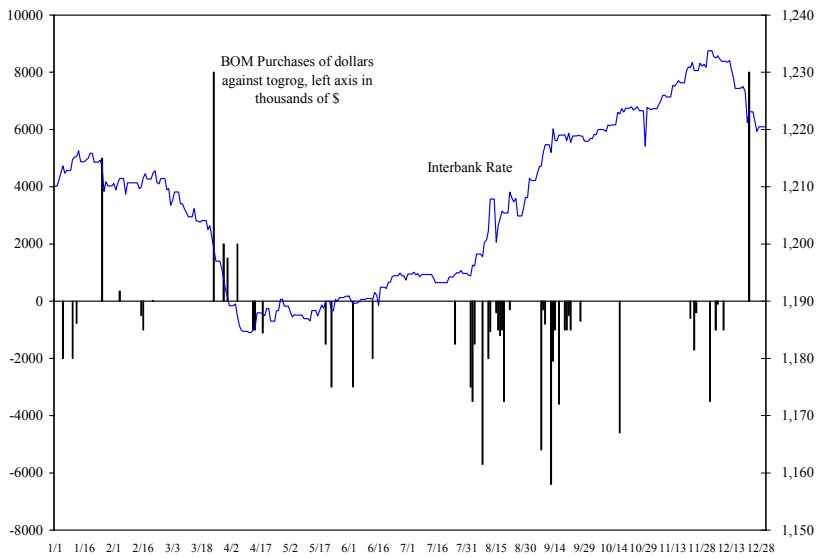
Source: Data provided by the Bank of Mongolia.

$1 /$ Intervention in thousands of US\$ on the left axis, with positive interventions representing purchases of U.S. dollar; Exchange rate movements (togrog/\$) on the right axis.

of the BOM's interventions, with U.S. dollar purchases generally made during periods of U.S. dollar depreciation (i.e., when there is an oversupply of U.S. dollars in the market) while U.S. dollar sales generally occurring during periods of U.S. dollar appreciation. The interventions may have reduced the magnitude of the appreciation/depreciation (in other words, the volatility), but have not fundamentally changed the trend of exchange rate movements.

92. The BOM's midpoint rate seems to affect the market rate. At this rate adjusted by trading margins, the BOM provides the market with an additional source of liquidity and arbitrage opportunities, conceptually it should therefore also affect the market rate. In addition, because the midpoint rate is essentially the lagged market rate, it should help reduce the market volatility. On the other hand, because the BOM has the option to decline foreign exchange requests from commercial banks, the impact of the midpoint rate on the market rate, if any, could be rather limited. Granger Causality tests suggest that the midpoint rate seems to affect the market rate. 


\section{Box IV.1. Does BOM's Midpoint Rate Affect the Market Rate?}

The following Granger Causality test was used:

$$
\mathrm{y}_{\mathrm{t}}=\alpha_{0}+\alpha_{1} \mathrm{y}_{\mathrm{t}-1}+\ldots+\alpha_{4} \mathrm{y}_{\mathrm{t}-4}+\beta_{1} \mathrm{x}_{\mathrm{t}-1} \ldots+\beta_{4} \mathrm{x}_{\mathrm{t}-4}+\varepsilon_{\mathrm{t}}
$$

- Two versions of $y_{t}$ are used: (i) the level; and (ii) the first difference of the interbank rate. For the former, the level of BOM rate is used as $x_{t .}$ For the latter, two versions of $x_{t}$ are used: (i) the first difference of the BOM rate; and (ii) the difference of the BOM rate and the lagged interbank rate.

- Daily data from January 2001 to July 2006 with 4 lags are used, although the results are robust to different lag lengths. The purpose is to test if the current and/or lagged BOM rates can help explain current interbank rates, after controlling for lagged interbank rates.

- The null hypothesis of no Granger Causality can be rejected in all three cases, with p-values close to zero. This evidence is consistent with the hypothesis that the BOM rate affects the interbank rate. Nevertheless, because the Granger Causality tests are best described as tests of whether $\mathrm{x}$ helps forecast $\mathrm{y}$ rather than tests of whether $\mathrm{x}$ causes $\mathrm{y}$, one needs to be cautious in concluding causation. 
Table 1. Mongolia: Basic Data, 2001-06

\begin{tabular}{|c|c|c|c|c|c|c|}
\hline & 2001 & 2002 & 2003 & 2004 & 2005 & $\frac{2006}{\text { Est. }}$ \\
\hline \multicolumn{7}{|l|}{ Population } \\
\hline Total population (million; mid-year) & 2.4 & 2.5 & 2.5 & 2.5 & 2.6 & 2.6 \\
\hline Population growth rate (annual percentage change) & 1.4 & 1.4 & 1.4 & 1.4 & 1.4 & 1.4 \\
\hline \multicolumn{7}{|l|}{ Income } \\
\hline \multicolumn{7}{|l|}{ Gross domestic product (at current market prices) } \\
\hline (In billions of trogog) & 1,118 & 1,245 & 1,474 & 1,926 & 2,489 & 3,306 \\
\hline (In millions of U.S. dollars) & 1,018 & 1,121 & 1,285 & 1,625 & 2,065 & 2,788 \\
\hline (In U.S. dollars; per capita) & 417 & 453 & 513 & 642 & 806 & 1,075 \\
\hline & \multicolumn{6}{|c|}{ (Annual percentage change) } \\
\hline \multicolumn{7}{|l|}{ Real GDP } \\
\hline Real gross domestic product (at constant 2000 prices) & 1.1 & 4.2 & 6.1 & 10.8 & 7.0 & 7.0 \\
\hline Mineral real GDP & 9.0 & -8.2 & -2.3 & 34.3 & 10.9 & 5.2 \\
\hline Nonmineral real GDP & 0.1 & 5.9 & 7.1 & 8.1 & 6.5 & 7.3 \\
\hline Agriculture & -18.3 & -12.5 & 4.9 & 17.7 & 11.0 & $\ldots$ \\
\hline \multirow[t]{2}{*}{ Other } & 9.1 & 12.6 & 7.8 & 5.5 & 5.1 & $\ldots$ \\
\hline & \multicolumn{6}{|c|}{ (In percent of GDP) } \\
\hline \multicolumn{7}{|l|}{ Savings-investment balance } \\
\hline Gross national savings & 36.0 & 29.7 & 38.0 & 45.0 & 43.5 & $\ldots$ \\
\hline Government & 4.8 & 4.4 & 7.5 & 8.6 & 9.3 & $\ldots$ \\
\hline Private & 31.2 & 25.4 & 30.5 & 36.4 & 34.2 & $\ldots$ \\
\hline Gross investment & 43.6 & 39.3 & 45.7 & 43.4 & 42.1 & $\ldots$ \\
\hline \multirow[t]{2}{*}{ Savings-investment balance } & -7.6 & -9.6 & -7.7 & 1.6 & 1.4 & 5.2 \\
\hline & \multicolumn{6}{|c|}{ (Annual percentage change) } \\
\hline \multicolumn{7}{|l|}{ Inflation } \\
\hline Period average & 8.0 & 1.0 & 5.1 & 8.3 & 12.1 & 5.6 \\
\hline End of period & 7.9 & 1.6 & 4.7 & 11.0 & 9.5 & 7.0 \\
\hline \multirow[t]{2}{*}{ GDP deflator } & 8.4 & 7.0 & 11.6 & 18.0 & 20.7 & 24.1 \\
\hline & & & percent & DP) & & \\
\hline General government budget & & & & & & \\
\hline Total revenue and grants & 38.4 & 38.3 & 37.6 & 37.0 & 33.7 & 40.6 \\
\hline Mineral revenue & 1.5 & 1.8 & 2.8 & 4.1 & 4.5 & 10.1 \\
\hline Nonmineral revenue and grants & 36.9 & 36.5 & 34.8 & 32.9 & 29.2 & 30.6 \\
\hline Total expenditure and net lending & 43.8 & 44.2 & 41.8 & 39.1 & 30.7 & 31.7 \\
\hline Overall balance & -5.4 & -5.9 & -4.2 & -2.1 & 2.9 & 9.0 \\
\hline Nonmineral overall balance & -6.9 & -7.7 & -7.0 & -6.3 & -1.5 & -4.5 \\
\hline & & al percen & change; & s otherw & dicated) & \\
\hline Money and credit & & & & & & \\
\hline Broad money & 28.0 & 41.9 & 49.7 & 20.3 & 37.3 & 34.9 \\
\hline Reserve money & 8.4 & 21.7 & 14.7 & 16.8 & 19.7 & 16.5 \\
\hline Claims on nonbanks & 101.5 & 70.4 & 90.3 & 43.7 & 40.1 & 39.2 \\
\hline Interest rates (Central bank bills; in percent) & 8.8 & 8.0 & 15.0 & 15.8 & 3.7 & 5.8 \\
\hline & & & percent & DP) & & \\
\hline Balance of payments & & & & & & \\
\hline Current account balance (Excluding official transfers) & -14.6 & -14.3 & -11.5 & -3.7 & -2.8 & 2.0 \\
\hline Current account balance (Including official transfers) & -7.6 & -9.6 & -7.7 & 1.6 & 1.4 & 5.2 \\
\hline Exports & 51.4 & 46.7 & 48.8 & 53.7 & 51.7 & 55.5 \\
\hline Of which: mineral exports & 24.3 & 25.4 & 27.3 & 34.2 & 36.6 & $\ldots$ \\
\hline Imports & 68.1 & 67.1 & 64.3 & 62.8 & 59.2 & 55.0 \\
\hline Of which: petroleum products & 12.2 & 10.2 & 10.8 & 12.9 & 13.2 & $\ldots$ \\
\hline & & nillions U & ollars; un & therwise & cated) & \\
\hline Foreign exchange reserves & & & & & & \\
\hline Gross official reserves & 207 & 271 & 178 & 208 & 333 & 626 \\
\hline (In months of next year's imports of goods and services) & 2.6 & 3.0 & 1.5 & 1.6 & 2.1 & 3.4 \\
\hline Public and publicly guaranteed debt & & & & & & \\
\hline Total public debt (In percent of GDP) & 89.0 & 91.4 & 112.8 & 93.0 & 68.3 & 53.6 \\
\hline Domestic debt (In percent of GDP) & 4.8 & 3.0 & 14.8 & 7.6 & 4.2 & 2.6 \\
\hline External debt & 854 & 978 & 1,237 & 1,361 & 1,308 & 1,405 \\
\hline (In percent of GDP) & 84.2 & 88.4 & 98.2 & 85.4 & 64.1 & 51.0 \\
\hline Debt service & 34 & 32 & 284 & 91 & 43 & 42 \\
\hline (In percent of exports of goods and services) & 5.3 & 4.5 & 34.0 & 7.5 & 2.9 & 2.1 \\
\hline & & & millions & Rs) & & \\
\hline Fund quota & & & & & & \\
\hline & 51.1 & 51.1 & 51.1 & 51.1 & 51.1 & 51.1 \\
\hline & & & grog per & dollar) & & \\
\hline Exchange rate & & & & & & \\
\hline Period average & 1,098 & 1,110 & 1,147 & 1,185 & 1,205 & 1,186 \\
\hline End of period & 1,102 & 1,125 & 1,168 & 1,209 & 1,221 & 1,164 \\
\hline
\end{tabular}

Sources: Data provided by the Mongolian authorities; and Fund staff estimates. 
Table 2. Mongolia: GDP by Sector at Current Market Prices, 2001-05

\begin{tabular}{|c|c|c|c|c|c|}
\hline & 2001 & 2002 & 2003 & 2004 & 2005 \\
\hline & \multicolumn{5}{|c|}{ (In billions of togrogs) } \\
\hline Nominal GDP & 1,118 & 1,245 & 1,474 & 1,926 & 2,489 \\
\hline Mineral & 101 & 126 & 186 & 366 & 616 \\
\hline Non-mineral & 1,017 & 1,119 & 1,288 & 1,561 & 1,873 \\
\hline Of which: Excluding agriculture, hunting, forestry, and fishery & 739 & 862 & 994 & 1,162 & 1,383 \\
\hline Formal sector & 968 & 1,075 & 1,267 & 1,728 & 2,273 \\
\hline Informal sector & 150 & 170 & 206 & 198 & 216 \\
\hline \multicolumn{6}{|l|}{ Nominal GDP by Sector } \\
\hline Agriculture, hunting, forestry and fishery & 278 & 257 & 293 & 399 & 491 \\
\hline Secondary sector & 247 & 282 & 376 & 577 & 883 \\
\hline Mining, quarrying, and petroleum & 101 & 126 & 186 & 366 & 616 \\
\hline Manufacturing & 90 & 78 & 90 & 98 & 131 \\
\hline Electricity, gas and water & 33 & 47 & 49 & 61 & 76 \\
\hline Construction & 23 & 31 & 51 & 52 & 60 \\
\hline Services & 593 & 707 & 804 & 950 & 1,116 \\
\hline Wholesale and retail trade & 298 & 344 & 387 & 465 & 540 \\
\hline Hotel and restaurants & 14 & 15 & 16 & 20 & 25 \\
\hline Transport, storage and communication & 145 & 183 & 203 & 241 & 301 \\
\hline Financial intermediation & 36 & 42 & 62 & 81 & 100 \\
\hline Real estate and other services & 12 & 15 & 22 & 28 & 29 \\
\hline Public administration & 48 & 56 & 62 & 71 & 80 \\
\hline Education & 50 & 57 & 66 & 66 & 74 \\
\hline Health and social services & 21 & 23 & 25 & 33 & 35 \\
\hline Other community, social and personal services & 5 & 7 & 8 & 10 & 13 \\
\hline \multirow[t]{2}{*}{ Less: Indirect services of financial organizations } & -35 & -35 & -48 & -65 & -80 \\
\hline & \multicolumn{5}{|c|}{ (In percent of GDP) } \\
\hline \multicolumn{6}{|l|}{ Memoranda items: } \\
\hline Nominal GDP & 100.0 & 100.0 & 100.0 & 100.0 & 100.0 \\
\hline Mineral & 9.0 & 10.1 & 12.6 & 19.0 & 24.7 \\
\hline Nonmineral & 91.0 & 89.9 & 87.4 & 81.0 & 75.3 \\
\hline Of which: Excluding agriculture, hunting, forestry, and fishery & 66.1 & 69.3 & 67.5 & 60.3 & 55.5 \\
\hline Formal sector & 86.6 & 86.3 & 86.0 & 89.7 & 91.3 \\
\hline Informal sector & 13.4 & 13.7 & 14.0 & 10.3 & 8.7 \\
\hline Agriculture, hunting, forestry and fishery & 24.8 & 20.6 & 19.9 & 20.7 & 19.7 \\
\hline Secondary sector & 22.1 & 22.6 & 25.5 & 30.0 & 35.5 \\
\hline Mining, quarrying, and petroleum & 9.0 & 10.1 & 12.6 & 19.0 & 24.7 \\
\hline Manufacturing & 8.1 & 6.3 & 6.1 & 5.1 & 5.2 \\
\hline Electricity, gas and water & 2.9 & 3.8 & 3.3 & 3.2 & 3.1 \\
\hline Construction & 2.0 & 2.5 & 3.4 & 2.7 & 2.4 \\
\hline Services & 53.1 & 56.8 & 54.6 & 49.3 & 44.8 \\
\hline Wholesale and retail trade & 26.6 & 27.6 & 26.3 & 24.1 & 21.7 \\
\hline Hotel and restaurants & 1.3 & 1.2 & 1.1 & 1.0 & 1.0 \\
\hline Transport, storage and communication & 13.0 & 14.7 & 13.8 & 12.5 & 12.1 \\
\hline Financial intermediation & 3.2 & 3.3 & 4.2 & 4.2 & 4.0 \\
\hline Real estate and other services & 1.1 & 1.2 & 1.5 & 1.5 & 1.2 \\
\hline Public administration & 4.3 & 4.5 & 4.2 & 3.7 & 3.2 \\
\hline Education & 4.5 & 4.6 & 4.5 & 3.4 & 3.0 \\
\hline Health and social services & 1.8 & 1.8 & 1.7 & 1.7 & 1.4 \\
\hline Other community, social and personal services & 0.4 & 0.6 & 0.5 & 0.5 & 0.5 \\
\hline Less: Indirect services of financial organizations & -3.1 & -2.9 & -3.2 & -3.4 & -3.2 \\
\hline
\end{tabular}

Source: Data Provided by the National Statistical Office. 
Table 3. Mongolia: GDP by Sector at 2000 Constant Prices, 2001-05

\begin{tabular}{|c|c|c|c|c|c|}
\hline & 2001 & 2002 & 2003 & 2004 & 2005 \\
\hline & \multicolumn{5}{|c|}{ (In billions of togrog) } \\
\hline Real GDP & 1,031 & 1,074 & 1,140 & 1,262 & 1,351 \\
\hline Mineral & 127 & 116 & 114 & 152 & 169 \\
\hline Non-mineral & 905 & 958 & 1,026 & 1,110 & 1,182 \\
\hline Of which: Excluding agriculture, hunting, forestry, and fishery & 663 & 746 & 804 & 848 & 892 \\
\hline \multicolumn{6}{|l|}{ Real GDP by Sector } \\
\hline Agriculture, hunting, forestry and fishery & 242 & 212 & 222 & 262 & 290 \\
\hline Secondary sector & 259 & 270 & 286 & 327 & 331 \\
\hline Mining, quarrying, and petroleum & 127 & 116 & 114 & 152 & 169 \\
\hline Manufacturing & 85 & 101 & 105 & 106 & 87 \\
\hline Electricity, gas and water & 25 & 26 & 26 & 28 & 28 \\
\hline Construction & 23 & 27 & 41 & 40 & 46 \\
\hline Services & 530 & 593 & 632 & 673 & 730 \\
\hline Wholesale and retail trade & 258 & 299 & 312 & 330 & 351 \\
\hline Hotel and restaurants & 13 & 13 & 13 & 15 & 17 \\
\hline Transport, storage and communication & 127 & 147 & 163 & 180 & 216 \\
\hline Financial intermediation & 31 & 35 & 46 & 56 & 64 \\
\hline Real estate and other services & 12 & 14 & 17 & 20 & 21 \\
\hline Public administration & 44 & 44 & 43 & 45 & 46 \\
\hline Education & 47 & 50 & 48 & 44 & 43 \\
\hline Health and social services & 20 & 20 & 20 & 21 & 21 \\
\hline Other community, social and personal services & 4 & 5 & 6 & 6 & 7 \\
\hline \multirow[t]{2}{*}{ Less: Indirect services of financial organizations } & -25 & -34 & -36 & -44 & -56 \\
\hline & \multicolumn{5}{|c|}{ (Annual percentage change) } \\
\hline \multicolumn{6}{|l|}{ Memoranda items: } \\
\hline Real GDP & 1.1 & 4.2 & 6.1 & 10.8 & 7.0 \\
\hline Mineral & 9.0 & -8.2 & -2.3 & 34.3 & 10.9 \\
\hline Nonmineral & 0.1 & 5.9 & 7.1 & 8.1 & 6.5 \\
\hline Of which: Excluding agriculture, hunting, forestry, and fishery & 9.1 & 12.6 & 7.8 & 5.5 & 5.1 \\
\hline Agriculture, forestry and fishing & -18.3 & -12.5 & 4.9 & 17.7 & 11.0 \\
\hline Secondary sector & 15.4 & 4.1 & 5.9 & 14.5 & 1.2 \\
\hline Mining, quarrying, and petroleum & 9.0 & -8.2 & -2.3 & 34.3 & 10.9 \\
\hline Manufacturing & 33.2 & 19.0 & 4.3 & 1.3 & -17.9 \\
\hline Electricity, gas and water & 2.7 & 3.2 & 1.1 & 6.3 & 0.8 \\
\hline Construction & 11.9 & 18.0 & 52.6 & -1.6 & 15.4 \\
\hline Services & 4.7 & 11.8 & 6.6 & 6.6 & 8.4 \\
\hline Wholesale and retail trade & 5.3 & 16.3 & 4.1 & 5.8 & 6.3 \\
\hline Hotel and restaurants & -6.9 & 3.7 & 0.5 & 17.3 & 12.1 \\
\hline Transport, storage and communication & 12.9 & 15.9 & 11.1 & 10.6 & 19.7 \\
\hline Financial intermediation & 22.0 & 10.7 & 32.5 & 21.7 & 14.3 \\
\hline Real estate and other services & 4.1 & 23.4 & 19.3 & 16.6 & 3.8 \\
\hline Public administration & -5.7 & -0.8 & -2.5 & 4.0 & 3.4 \\
\hline Education & 1.1 & 4.7 & -4.3 & -6.6 & -3.0 \\
\hline Health and social services & 3.8 & 1.2 & -2.1 & 5.3 & 0.4 \\
\hline Other community, social and personal services & -0.9 & 27.9 & 36.9 & -4.2 & 21.6 \\
\hline Less: Indirect services of financial organizations & 43.6 & 36.1 & 5.4 & 23.9 & 26.5 \\
\hline
\end{tabular}

Source: Data Provided by the National Statistical Office. 
Table 4. Mongolia: GDP Deflator by Sector, 2001-05

\begin{tabular}{|c|c|c|c|c|c|}
\hline & 2001 & 2002 & 2003 & 2004 & 2005 \\
\hline & \multicolumn{5}{|c|}{ (Annual percentage change) } \\
\hline GDP deflator & 8.4 & 7.0 & 11.6 & 18.0 & 20.7 \\
\hline Mineral GDP & -20.4 & 36.1 & 51.1 & 46.5 & 51.8 \\
\hline Nonmineral GDP & 12.4 & 3.9 & 7.4 & 12.1 & 12.7 \\
\hline Of which : Excluding agriculture, hunting, forestry, and fishery & 11.5 & 3.6 & 7.0 & 10.7 & 13.2 \\
\hline \multicolumn{6}{|l|}{ GDP deflator by Sector } \\
\hline Agriculture, hunting, forestry, and fishery & 14.7 & 5.6 & 9.0 & 15.6 & 10.8 \\
\hline \multicolumn{6}{|l|}{ Secondary sector } \\
\hline Mining, quarrying, and petroleum & -20.4 & 36.1 & 51.1 & 46.5 & 51.8 \\
\hline Manufacturing & 6.6 & -27.3 & 11.2 & 7.5 & 61.4 \\
\hline Electricity, gas and water & 30.3 & 37.6 & 4.0 & 17.0 & 23.2 \\
\hline Construction & 1.1 & 15.1 & 7.0 & 3.8 & 1.0 \\
\hline \multicolumn{6}{|l|}{ Services } \\
\hline Wholesale and retail trade & 12.2 & 2.4 & 5.0 & 13.0 & 10.6 \\
\hline Hotel and restaurants & 12.7 & 4.3 & 5.8 & 3.4 & 10.8 \\
\hline Transport, storage and communication & 14.4 & 8.8 & -0.2 & 7.4 & 4.6 \\
\hline Financial intermediation & 14.0 & 5.7 & 12.7 & 7.7 & 6.9 \\
\hline Real estate and other services & 4.0 & 4.3 & 21.2 & 9.1 & -2.2 \\
\hline Public administration & 8.6 & 17.1 & 13.0 & 10.4 & 8.7 \\
\hline Education & 5.5 & 9.4 & 20.5 & 6.2 & 16.3 \\
\hline Health and social services & 3.4 & 8.0 & 15.4 & 22.7 & 6.8 \\
\hline Other community, social and personal services & 6.0 & 5.0 & 17.9 & 6.9 & 6.6 \\
\hline Less: Indirect services of financial organizations & 3.9 & -4.2 & 8.3 & 7.8 & 6.9 \\
\hline
\end{tabular}

Source: Data Provided by the National Statistical Office. 
Table 5. Mongolia: Gross National Disposable Income and Savings at Current Market Prices, 2001-05

\begin{tabular}{|c|c|c|c|c|c|}
\hline & 2001 & 2002 & 2003 & 2004 & 2005 \\
\hline & \multicolumn{5}{|c|}{ (In billions of togrog) } \\
\hline Final consumption & 1,052 & 1,194 & 1,278 & 1,509 & 1,753 \\
\hline Private & 842 & 967 & 1,032 & 1,196 & 1,408 \\
\hline Government & 211 & 227 & 246 & 313 & 344 \\
\hline Gross investment & 487 & 490 & 673 & 835 & 1,048 \\
\hline Gross fixed capital formation & 436 & 451 & 615 & 754 & 987 \\
\hline Change in inventories $1 /$ & 51 & 39 & 57 & 81 & 61 \\
\hline Domestic demand & 1,539 & 1,684 & 1,951 & 2,345 & 2,801 \\
\hline Foreign balance (net) & -211 & -267 & -285 & -231 & -109 \\
\hline Exports of goods and services $2 /$ & 699 & 787 & 958 & 1,434 & 1,787 \\
\hline Imports of goods and services $2 /$ & -910 & $-1,054$ & $-1,243$ & $-1,665$ & $-1,896$ \\
\hline Statistical discrepancy $3 /$ & -211 & -172 & -193 & -188 & -203 \\
\hline Gross domestic product 4/ & 1,118 & 1,245 & 1,474 & 1,926 & 2,489 \\
\hline Income from abroad (net) 2/ & 3 & -5 & -13 & -56 & -127 \\
\hline Gross national income (GNI) 5/ & 1,121 & 1,240 & 1,460 & 1,870 & 2,362 \\
\hline Current transfers (net) 2/ & 123 & 153 & 185 & 318 & 271 \\
\hline \multirow[t]{2}{*}{ Gross national disposable income (GNDI) 6/ } & 1,244 & 1,393 & 1,646 & 2,188 & 2,633 \\
\hline & \multicolumn{5}{|c|}{ (In percent of GDP) } \\
\hline \multicolumn{6}{|l|}{ Memoranda items: } \\
\hline Gross domestic product & 100.0 & 100.0 & 100.0 & 100.0 & 100.0 \\
\hline Domestic demand $7 /$ & 118.9 & 121.5 & 119.3 & 112.0 & 104.4 \\
\hline Final Consumption 7/ & 75.3 & 82.1 & 73.7 & 68.6 & 62.2 \\
\hline Private $7 /$ & 56.5 & 63.9 & 57.0 & 52.4 & 48.4 \\
\hline Government & 18.8 & 18.3 & 16.7 & 16.2 & 13.8 \\
\hline Gross investment & 43.6 & 39.3 & 45.7 & 43.4 & 42.1 \\
\hline Foreign balance (net) 2/ & -18.9 & -21.5 & -19.3 & -12.0 & -4.4 \\
\hline Exports of goods and services $2 /$ & 62.5 & 63.2 & 65.0 & 74.5 & 71.8 \\
\hline Imports of goods and services $2 /$ & -81.4 & -84.7 & -84.3 & -86.4 & -76.2 \\
\hline Statistical discrepancy $3 /$ & -18.8 & -13.8 & -13.1 & -9.7 & -8.2 \\
\hline Gross domestic savings 8/ & 24.7 & 17.9 & 26.3 & 31.4 & 37.8 \\
\hline Gross national savings 9/ & 36.0 & 29.7 & 38.0 & 45.0 & 43.5 \\
\hline Government savings $10 /$ & 4.8 & 4.4 & 7.5 & 8.6 & 9.3 \\
\hline Private savings & 31.2 & 25.4 & 30.5 & 36.4 & 34.2 \\
\hline Savings-investment balance & -7.6 & -9.6 & -7.7 & 1.6 & 1.4 \\
\hline
\end{tabular}

Sources: Data Provided by the National Statistical Office; and IMF staff estimates.

$1 /$ Including acquisitions less disposal of valuables.

2/ Forced to be consistent with the latest balance of payments data.

3/ Difference between output-based and expenditure-based GDP estimates.

4/ Output-based GDP.

5/ GNI is defined as the sum of GDP and net income from abroad.

6/ GNDI is defined as the sum of GNI and net transfers.

7/ Including statistical discrepancy.

8/ Defined as the difference between GDP and final consumption including the statistical discrepancy.

9/ Defined as the difference between GNDI and final consumption including the statistical discrepancy.

10/ Defined as the difference between current revenue and current expenditure. 
Table 6. Mongolia: Output of Major Agricultural Products, 2001-05

\begin{tabular}{|c|c|c|c|c|c|}
\hline & 2001 & 2002 & 2003 & 2004 & 2005 \\
\hline & \multicolumn{5}{|c|}{ (In thousands of metric tons; unless otherwise indicated) } \\
\hline Meat & 468.1 & 413.1 & 318.1 & 424.5 & 403.0 \\
\hline Milk (million tons) & 290.3 & 276.6 & 292.4 & 328.6 & 335.1 \\
\hline Eggs (millions) & 7.7 & 4.2 & 7.1 & 16.0 & 21.3 \\
\hline Wool & 19.8 & 17.0 & 15.2 & 15.3 & 22.6 \\
\hline Wheat & 138.7 & 123.1 & 160.4 & 135.6 & 73.5 \\
\hline Cereals & 142.2 & 125.9 & 165.0 & 138.5 & 75.5 \\
\hline Potatoes & 58.3 & 51.9 & 78.7 & 80.2 & 82.8 \\
\hline \multirow[t]{2}{*}{ Other vegetables } & 44.5 & 39.7 & 59.6 & 49.2 & 64.1 \\
\hline & \multicolumn{5}{|c|}{ (In millions of head) } \\
\hline Livestock & 26.1 & 23.9 & 25.5 & 28.0 & 30.4 \\
\hline Sheep & 11.9 & 10.6 & 10.8 & 11.7 & 12.9 \\
\hline Goats & 9.6 & 9.1 & 10.7 & 12.2 & 13.3 \\
\hline Cattle & 2.1 & 1.9 & 1.8 & 1.8 & 1.9 \\
\hline Horses & 2.2 & 2.0 & 1.9 & 2.0 & 2.0 \\
\hline \multirow[t]{2}{*}{ Camels } & 0.3 & 0.3 & 0.3 & 0.3 & 0.3 \\
\hline & \multicolumn{5}{|c|}{ (Percent change) } \\
\hline Meat & -26.8 & -11.8 & -23.0 & 33.5 & -5.0 \\
\hline Milk & -22.7 & -4.7 & 5.7 & 12.4 & 2.0 \\
\hline Eggs & 14.9 & -45.5 & 69.1 & 125.3 & 33.0 \\
\hline Wool & -8.8 & -14.1 & -10.6 & 0.6 & 48.0 \\
\hline Cereals & 0.1 & -11.5 & 31.0 & -16.1 & -46.0 \\
\hline Potatoes & -0.9 & -10.9 & 51.6 & 1.9 & -45.0 \\
\hline \multirow[t]{2}{*}{ Other vegetables } & 14.4 & -10.8 & 50.1 & -17.5 & 30.0 \\
\hline & \multicolumn{5}{|c|}{ (In percent of total head) } \\
\hline \multicolumn{6}{|l|}{ Memorandum item: } \\
\hline Privately owned livestock & 97.2 & 97.4 & 97.9 & 98.2 & 98.4 \\
\hline
\end{tabular}

Source: Data provided by the National Statistical Office. 
Table 7. Mongolia: Output of Basic Industrial and Mining Products, 2001-05

(In thousands of metric tons; unless otherwise indicated)

\begin{tabular}{|c|c|c|c|c|c|}
\hline & 2001 & 2002 & 2003 & 2004 & 2005 \\
\hline Electricity (million kilowatt hours) & $3,017.0$ & $3,111.7$ & $3,137.7$ & $3,303.4$ & $3,418.9$ \\
\hline Coal & $5,141.0$ & $5,544.4$ & $5,666.1$ & $6,865.0$ & $7,517.1$ \\
\hline Fluor spar & 584.7 & 513.9 & 488.2 & 468.2 & 507.9 \\
\hline Copper concentrate & 381.4 & 376.3 & 372.2 & 371.4 & 361.6 \\
\hline Gold concentrate (kilograms) & $13,674.6$ & $12,097.1$ & $11,118.6$ & $19,417.6$ & $24,121.9$ \\
\hline Bricks (millions) & 21.0 & 13.2 & 22.9 & 12.5 & 14.6 \\
\hline Cement & 67.7 & 147.6 & 162.3 & 61.9 & 111.9 \\
\hline Lime & 30.1 & 42.5 & 42.1 & 30.0 & 81.2 \\
\hline Sawn timber (thousand of cubic meters) & 21.0 & 10.2 & 16.6 & 17.8 & 13.2 \\
\hline Scoured wool & 2.1 & 1.2 & 0.5 & 1.8 & 0.9 \\
\hline Felt (thousand meters) & 110.5 & 112.9 & 303.0 & 67.8 & 69.1 \\
\hline Woolen fabrics (thousand meters) & 43.1 & 38.3 & 27.4 & 36.8 & 33.5 \\
\hline Coats (thousands) & 0.0 & 0.0 & 0.2 & 0.1 & 0.2 \\
\hline Suits (thousands) & 16.0 & 60.7 & 73.5 & 98.5 & 59.8 \\
\hline Leather footwear (thousand pairs) & 16.7 & 9.5 & 4.6 & 3.0 & 3.0 \\
\hline Sheepskin coats (thousands) & 2.4 & 2.1 & 3.5 & 3.5 & 5.5 \\
\hline Meat (excluding pork) & 12.0 & 6.8 & 11.1 & 4.3 & 3.6 \\
\hline Sausages & 727.5 & 950.6 & $1,170.6$ & $1,272.2$ & $1,299.7$ \\
\hline Flour & 37.7 & 49.6 & 54.1 & 57.8 & 58.3 \\
\hline Bakery products & 30.2 & 28.5 & 29.1 & 31.2 & 31.4 \\
\hline Confectionery & 0.3 & 0.2 & 0.1 & 0.1 & 0.1 \\
\hline Milk and dairy products (million liters) & 1.2 & 3.2 & 5.2 & 5.9 & 7.1 \\
\hline Carpets (thousands of square meters) & 614.8 & 533.9 & 663.1 & 690.4 & 586.9 \\
\hline Processed metal & 28.2 & 26.3 & 60.0 & 84.4 & 101.7 \\
\hline
\end{tabular}

Source: Data provided by the National Statistical Office. 
Table 8. Mongolia: Gross Industrial Output at 2000 prices, 2001-05

(In billions of togrogs)

\begin{tabular}{lrrrrr}
\hline & 2001 & 2002 & 2003 & 2004 & 2005 \\
& & & & & \\
& 29.6 & 85.4 & 92.5 & 91.8 & 93.2 \\
Food & 0.7 & 0.7 & 0.7 & 0.3 & 0.2 \\
Leather and shoes & 28.8 & 106.4 & 91.5 & 98.6 & 63.8 \\
Textiles & 4.2 & 84.2 & 121.1 & 98.6 & 33.4 \\
Clothing & 43.8 & 97.4 & 98.4 & 102.6 & 107.7 \\
Energy 1/ & 13.5 & 13.9 & 14.6 & 17.8 & $\ldots$ \\
Coal & 109.4 & 273.6 & 260.2 & 368.1 & 409.4 \\
Mining of metal ores & 18.7 & 24.3 & 28.6 & 22.6 & 21.6 \\
Other mining and quarrying & 4.8 & 7.2 & 9.1 & 5.8 & 10.3 \\
Non-metallic products & 1.0 & 4.6 & 7.2 & 5.9 & 5.6 \\
Wood processing & 1.6 & 3.6 & 3.0 & 3.7 & 2.6 \\
Chemicals & 1.6 & 9.0 & 15.7 & 7.8 & 6.8 \\
Printing & 0.5 & 0.9 & 1.9 & 1.1 & 1.1 \\
Furniture & 3.6 & 72.9 & 85.1 & 95.3 & 108.6 \\
Other & & & & & \\
\hline
\end{tabular}

Source: Data provided by the National Statistical Office.

1/ Includes electric and thermal energy. 
Table 9. Mongolia: Coal Mining Sector, 2001-05

(In thousands of metric tons)

\begin{tabular}{lrrrrr}
\hline & 2001 & 2002 & 2003 & 2004 & 2005 \\
\hline & & & & & \\
Production & 5,141 & 5,544 & 5,666 & 6,865 & 7,517 \\
Imports & 10 & 0 & 0 & 0 & 0 \\
Consumption & 5,189 & 5,535 & 5,162 & 5,189 & 5,473 \\
$\quad$ Intermediate 1/ & 4,324 & 4,723 & 4,380 & 4,479 & 4,620 \\
$\quad$ Final consumption & 865 & 812 & 782 & 710 & 853 \\
$\quad$ Industry and construction & 152 & 152 & 154 & 91 & 107 \\
$\quad$ Agriculture & 4 & 8 & 9 & 5 & 18 \\
$\quad$ Communal housing and public services & 334 & 436 & 465 & 451 & 514 \\
$\quad$ Other & 375 & 217 & 155 & 163 & 214 \\
Exports & $\ldots$ & $\ldots$ & 435 & 1,560 & 2,116 \\
Memorandum item: & & & & & 272 \\
$\quad$ Stock; end of year & 148 & 157 & 227 & 343 & \\
\hline
\end{tabular}

Source: Data provided by the National Statistical Office.

$1 /$ Consumption by thermal power stations. 
Table 10. Mongolia: Petroleum Imports, 2001-05

\begin{tabular}{|c|c|c|c|c|c|}
\hline & 2001 & 2002 & 2003 & 2004 & 2005 \\
\hline & \multicolumn{5}{|c|}{ (In thousands of metric tons) } \\
\hline Total petroleum imports & 487.5 & 470.6 & 512.9 & 563.9 & 551.3 \\
\hline Petro & 247.2 & 243.7 & 259.1 & 270.1 & 254.8 \\
\hline Diesel & 197.1 & 190.6 & 214.8 & 258.2 & 270.9 \\
\hline Jet fuel & 22.8 & 20.5 & 23.9 & 22.8 & 18.9 \\
\hline Mazut & 17.5 & 9.5 & 12.4 & 11.1 & 4.9 \\
\hline \multirow[t]{2}{*}{ Lubricants } & 2.9 & 6.3 & 2.7 & 1.7 & 1.8 \\
\hline & \multicolumn{5}{|c|}{ (In millions of U.S. dollars) } \\
\hline Total petroleum imports & 124.0 & 110.0 & 142.5 & 210.2 & 291.0 \\
\hline
\end{tabular}

Source: Data provided by the National Statistical Office. 
Table 11. Mongolia: Electricity Sector, 2001-05

\begin{tabular}{|c|c|c|c|c|c|}
\hline & 2001 & 2002 & 2003 & 2004 & 2005 \\
\hline & \multicolumn{5}{|c|}{ (In millions of kilowatt hours) } \\
\hline Supply & 3,213 & 3,279 & 3,309 & 3,474 & 3,586 \\
\hline Domestic & 3,017 & 3,112 & 3,138 & 3,304 & 3,419 \\
\hline Imports & 196 & 167 & 171 & 171 & 168 \\
\hline Uses & 3,213 & 3,279 & 3,309 & 3,474 & 3,586 \\
\hline Consumption & 1,948 & 2,032 & 2,195 & 2,357 & 2,534 \\
\hline Industry and construction & 1,204 & 1,260 & 1,361 & 1,459 & 1,569 \\
\hline Transport and communications & 87 & 85 & 92 & 99 & 106 \\
\hline Agriculture & 17 & 22 & 24 & 26 & 28 \\
\hline Commercial housing and public services & 476 & 487 & 526 & 568 & 609 \\
\hline Other sectors & 164 & 178 & 192 & 207 & 222 \\
\hline Loss in transmission and distribution & 603 & 583 & 489 & 480 & 420 \\
\hline Power stations' own use & 644 & 649 & 618 & 629 & 621 \\
\hline \multirow[t]{2}{*}{ Exports } & 18 & 16 & 7 & 8 & 12 \\
\hline & \multicolumn{5}{|c|}{ (Togrogs per kilowatt hour, annual average) } \\
\hline \multicolumn{6}{|l|}{ Tariff } \\
\hline Industry & 45 & 47 & 47 & 51 & 51 \\
\hline Agriculture & 45 & 47 & 47 & 51 & 51 \\
\hline Households & 45 & 47 & 47 & 49 & 51 \\
\hline & \multicolumn{5}{|c|}{ (Percent change) } \\
\hline Supply and uses & 2.8 & 2.1 & 0.9 & 5.0 & 3.2 \\
\hline Supply & & & & & \\
\hline Domestic & 2.4 & 3.1 & 0.8 & 5.3 & 3.5 \\
\hline Imports & 8.3 & -14.6 & 2.4 & -0.3 & -1.9 \\
\hline \multicolumn{6}{|l|}{ Uses } \\
\hline Consumption & 2.0 & 4.3 & 8.0 & 7.4 & 7.5 \\
\hline Industry and construction & 1.9 & 4.7 & 8.0 & 7.2 & 7.6 \\
\hline Transport and communications & 10.1 & -2.6 & 8.0 & 7.7 & 7.4 \\
\hline Agriculture & -19.0 & 29.4 & 8.2 & 7.6 & 7.4 \\
\hline Commercial housing and public services & 2.8 & 2.3 & 8.0 & 7.9 & 7.3 \\
\hline Other sectors & -0.6 & 8.4 & 8.0 & 7.5 & 7.7 \\
\hline $\begin{array}{l}\text { Loss in transmission and power stations' own use in } \\
\text { total supply (in percent) }\end{array}$ & 38.8 & 37.6 & 33.5 & 31.9 & 31.9 \\
\hline
\end{tabular}

Source: Data provided by the Ministry of Fuel and Energy. 
Table 12. Mongolia: Employment by Sector, 2001-05

(Number of employees; in thousands at end of year)

\begin{tabular}{lrrrrr}
\hline & 2001 & 2002 & 2003 & 2004 & 2005 \\
\hline Total employment 1/ & 832.3 & 870.8 & 926.5 & 950.5 & 968.3 \\
$\quad$ Agriculture and forestry & 402.4 & 391.4 & 387.5 & 381.8 & 386.2 \\
$\quad$ Industry & 93.3 & 99.2 & 109.5 & 114.2 & 113.9 \\
$\quad$ Transport and communications & 35.1 & 38.8 & 39.5 & 42.2 & 42.4 \\
$\quad$ Construction & 20.4 & 25.5 & 35.1 & 39.2 & 48.9 \\
$\quad$ Education & 55.2 & 59.3 & 55.3 & 57.8 & 58.8 \\
$\quad$ Health & 33.0 & 34.5 & 36.8 & 39.4 & 39.5 \\
$\quad$ Other & 192.9 & 222.1 & 262.8 & 275.9 & 278.6 \\
Memoranda items: & & & & & \\
Labor force & 872.6 & 901.7 & 959.8 & 986.1 & 1001.2 \\
$\quad$ Unemployed & 40.3 & 30.9 & 33.3 & 35.6 & 32.9 \\
\hline
\end{tabular}

Source: Data provided by the National Statistical Office.

1/ Excludes foreign employees. 
Table 13. Mongolia: Ulaanbaatar Consumer Prices, 2001-06 1/

$($ December $2000=100)$

\begin{tabular}{|c|c|c|c|c|c|c|}
\hline & 2001 & 2002 & 2003 & 2004 & 2005 & $\begin{array}{r}\frac{2006}{\text { Jan-Nov }} \\
\text {. }\end{array}$ \\
\hline & \multicolumn{6}{|c|}{ (Period average) } \\
\hline Overall index & 109.0 & 110.1 & 113.8 & 123.2 & 138.1 & 145.7 \\
\hline Flour and flour goods & 101.9 & 98.4 & 98.1 & 121.5 & 123.4 & 124.5 \\
\hline Meat and meat products & 137.5 & 137.9 & 159.2 & 187.2 & 251.4 & 265.8 \\
\hline Milk and diary products & 100.2 & 91.5 & 92.7 & 91.8 & 96.3 & 107.7 \\
\hline Sugar, candy, tea, fruits & 100.3 & 100.8 & 96.2 & 103.6 & 108.9 & 128.8 \\
\hline Potato and vegetables & 113.0 & 123.7 & 116.8 & 104.4 & 133.5 & 142.2 \\
\hline Other foodstuffs & 102.4 & 102.2 & 104.1 & 110.6 & 125.7 & 129.9 \\
\hline Alcohol and tobaccos & 112.4 & 115.9 & 112.5 & 117.3 & 115.4 & 129.8 \\
\hline Men's clothing & 103.6 & 108.4 & 110.2 & 112.8 & 115.8 & 125.4 \\
\hline Women's clothing & 102.0 & 100.5 & 100.5 & 99.2 & 101.2 & 110.1 \\
\hline Children's clothing & 99.5 & 101.8 & 117.4 & 118.3 & 128.2 & 133.4 \\
\hline Footwear & 99.8 & 98.7 & 106.9 & 108.8 & 108.3 & 109.7 \\
\hline Cloth & 98.4 & 100.4 & 118.8 & 124.6 & 139.8 & 145.8 \\
\hline Housing, heating, and electricity & 110.0 & 119.2 & 121.6 & 123.7 & 134.4 & 135.3 \\
\hline Household goods & 100.9 & 101.4 & 101.1 & 102.9 & 108.4 & 113.1 \\
\hline Medical care & 100.2 & 102.1 & 111.7 & 116.1 & 122.7 & 132.9 \\
\hline Transport and communication & 100.5 & 102.8 & 105.5 & 115.8 & 133.2 & 145.2 \\
\hline Education and recreation & 99.3 & 97.9 & 108.7 & 117.9 & 124.9 & 134.1 \\
\hline \multirow[t]{2}{*}{ Other goods and services } & 102.1 & 103.9 & 117.8 & 128.0 & 134.3 & 142.1 \\
\hline & \multicolumn{6}{|c|}{ (End of period) } \\
\hline Overall index & 108.0 & 109.7 & 114.9 & 127.5 & 139.6 & 147.2 \\
\hline Flour and flour goods & 103.0 & 94.5 & 110.1 & 124.9 & 122.3 & 126.4 \\
\hline Meat and meat products & 119.5 & 119.1 & 146.5 & 181.9 & 240.5 & 237.1 \\
\hline Milk and diary products & 106.4 & 107.0 & 102.0 & 101.4 & 111.9 & 114.1 \\
\hline Sugar, candy, tea, fruits & 99.8 & 95.4 & 97.2 & 103.8 & 113.5 & 125.6 \\
\hline Potato and vegetables & 106.1 & 121.0 & 85.5 & 107.1 & 129.3 & 130.4 \\
\hline Other foodstuffs & 104.8 & 102.7 & 105.0 & 116.5 & 129.2 & 133.6 \\
\hline Alcohol and tobaccos & 116.3 & 115.5 & 112.3 & 119.7 & 128.1 & 131.1 \\
\hline Men's clothing & 111.1 & 112.3 & 114.3 & 121.3 & 117.6 & 129.5 \\
\hline Women's clothing & 103.6 & 106.0 & 101.9 & 100.9 & 104.2 & 116.0 \\
\hline Children's clothing & 104.4 & 117.2 & 132.4 & 132.7 & 132.0 & 141.3 \\
\hline Footwear & 100.9 & 113.3 & 112.2 & 111.3 & 109.4 & 113.6 \\
\hline Cloth & 97.4 & 103.3 & 122.8 & 136.2 & 141.8 & 153.7 \\
\hline Housing, heating, and electricity & 122.2 & 126.8 & 125.3 & 130.2 & 135.8 & 147.6 \\
\hline Household goods & 101.4 & 103.8 & 100.8 & 105.9 & 111.4 & 119.5 \\
\hline Medical care & 99.4 & 108.5 & 113.9 & 118.0 & 126.5 & 154.9 \\
\hline Transport and communication & 101.0 & 105.1 & 107.2 & 130.7 & 138.5 & 147.7 \\
\hline Education ad recreation & 98.4 & 102.7 & 114.3 & 122.9 & 129.6 & 140.8 \\
\hline \multirow[t]{2}{*}{ Other goods and services } & 103.4 & 107.6 & 122.6 & 132.6 & 136.2 & 146.4 \\
\hline & \multicolumn{6}{|c|}{ (Percent change) } \\
\hline \multicolumn{7}{|l|}{ Memoranda items: } \\
\hline Annual average & 8.0 & 1.1 & 3.3 & 8.3 & 12.1 & 5.5 \\
\hline End of period & 8.0 & 1.6 & 4.7 & 11.0 & 9.5 & 5.5 \\
\hline
\end{tabular}

Source: Data provided by the National Statistical Office.

1/ The number of commodities comprising the consumer basket increased from 239 to 287 from December 2005. 


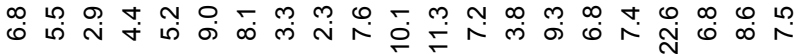

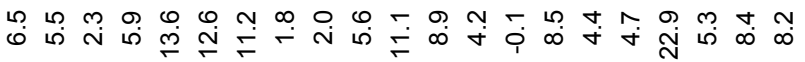

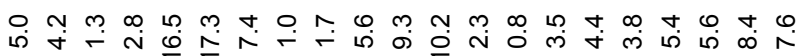
广

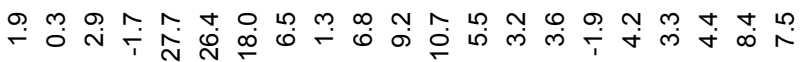
Nָ

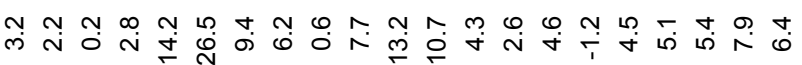
闭

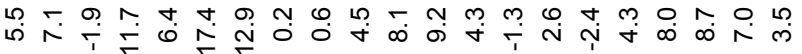
⿹弔㇒

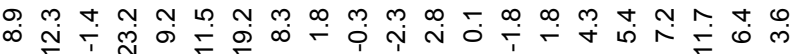
吊 車

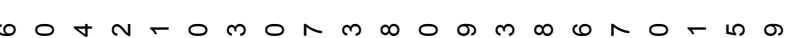
هํำ

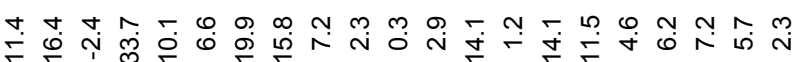
吊 ம F⿻上丨

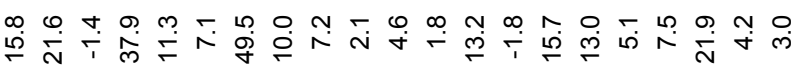

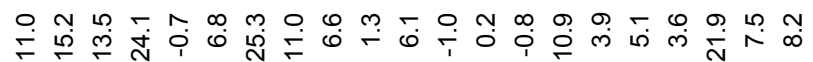

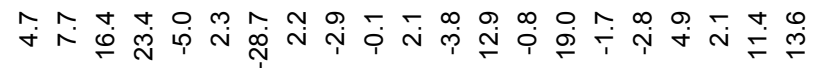

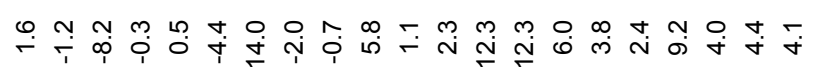
○ 这

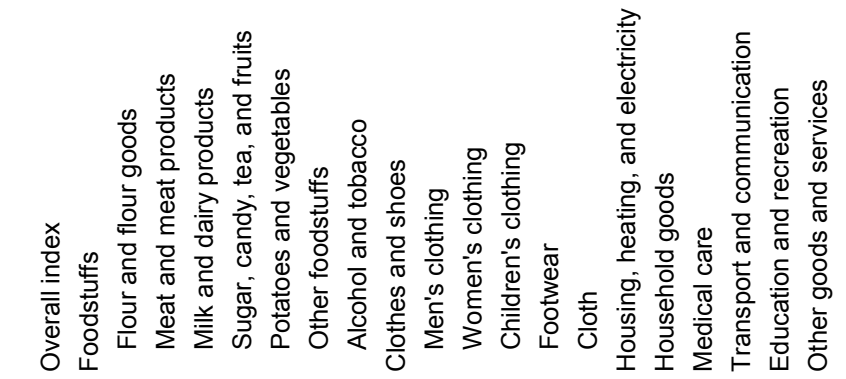


Table 15. Mongolia: Retail Prices, 2001-06

(End of period; in togrogs per kilogram; unless otherwise indicated)

\begin{tabular}{lcccccc}
\hline & 2001 & 2002 & 2003 & 2004 & 2005 & $\frac{2006}{\text { July }}$ \\
\hline Mutton & 959 & 950 & 1,227 & 1,500 & 2,003 & 2,590 \\
Beef & 1,088 & 1,081 & 1,327 & 1,733 & 2,265 & 2,767 \\
Flour & 362 & 297 & 409 & 442 & 397 & 408 \\
Bread & 266 & 266 & 288 & 312 & 320 & 320 \\
Sugar & 677 & 589 & 557 & 580 & 730 & 1,100 \\
Rice & 476 & 459 & 456 & 685 & 728 & $6951 /$ \\
Vegetable oil (liter) & 1,250 & 1,240 & 1,408 & 1,550 & 1,600 & 1,510 \\
Tea bricks (2 kilograms) & 2,397 & 2,267 & 1,947 & 2,400 & 2,720 & 2,614 \\
Tobacco & 1,520 & 1,600 & 1,650 & 1,650 & 1,775 & 1,850 \\
Gasoline A-93 (liter) & 410 & 435 & 520 & 673 & 800 & 850 \\
Gasoline A-76 (liter) & 375 & 400 & 470 & 600 & 736 & 780 \\
Diesel (liter) & 420 & 420 & 462 & 546 & 860 & 950 \\
\hline & & & & & & \\
\hline
\end{tabular}

Sources: Data provided by the National Statistical Office; and Neft Import Concern.

1/ Change in rice quality. 
Table 16. Mongolia: Privatization of State-Owned Enterprises, 2001-05 1/

\begin{tabular}{|c|c|c|}
\hline & $\begin{array}{l}\text { No. of Enterprises } \\
\text { Privatized }\end{array}$ & $\begin{array}{l}\text { Privatization Revenue } \\
\text { (million togrogs) }\end{array}$ \\
\hline \multicolumn{3}{|l|}{2001} \\
\hline Total privatization & 11 & 4,903 \\
\hline Large enterprises & 1 & 4,446 \\
\hline Construction sector & 0 & 0 \\
\hline Mineral sector & 0 & 0 \\
\hline Agriculture sector & 0 & 0 \\
\hline Other & 1 & 4,446 \\
\hline Small enterprises and assets & 10 & 457 \\
\hline \multicolumn{3}{|l|}{2002} \\
\hline Total privatization & 25 & 15,912 \\
\hline Large enterprises & 10 & 14,681 \\
\hline Construction sector & 3 & 456 \\
\hline Mineral sector & 0 & 0 \\
\hline Agriculture sector & 1 & 145 \\
\hline Other & 6 & 14,080 \\
\hline Small enterprises and assets & 15 & 1,231 \\
\hline \multicolumn{3}{|l|}{2003} \\
\hline Total privatization & 15 & 11,174 \\
\hline Large enterprises & 7 & 10,928 \\
\hline Construction sector & 2 & 106 \\
\hline Mineral sector & 0 & 0 \\
\hline Agriculture sector & 0 & 0 \\
\hline Other & 5 & 10,823 \\
\hline Small enterprises and assets & 8 & 245 \\
\hline \multicolumn{3}{|l|}{2004} \\
\hline Total privatization & 20 & 18,429 \\
\hline Large enterprises & 4 & 17,818 \\
\hline Construction sector & 0 & 0 \\
\hline Mineral sector & 0 & 0 \\
\hline Agriculture sector & 0 & 0 \\
\hline Other & 4 & 17,818 \\
\hline Small enterprises and assets & 16 & 611 \\
\hline \multicolumn{3}{|l|}{2005} \\
\hline Total privatization & 22 & 3,291 \\
\hline Large enterprises & 5 & 1,671 \\
\hline Construction sector & 0 & 0 \\
\hline Mineral sector & 2 & 95 \\
\hline Agriculture sector & 0 & 0 \\
\hline Other & 3 & 1,576 \\
\hline Small enterprises and assets & 17 & 1620.6 \\
\hline
\end{tabular}

Source: Data provided by the State Property Commission.

1/ Excludes privatization receipts of local governments. 
Table 17: Mongolia: Government Average Wages, 2001-05

\begin{tabular}{|c|c|c|c|c|c|}
\hline & 2001 & 2002 & 2003 & 2004 & 2005 \\
\hline Employment (thousands) & 133.7 & 135.6 & 132.2 & 120.5 & 115.9 \\
\hline Wage bill (billions of togrogs) & 92.1 & 105.0 & 116.9 & 128.8 & 132.4 \\
\hline Per capita wage (thousands of togrogs) & 688.6 & 774.3 & 884.3 & $1,068.9$ & $1,142.4$ \\
\hline Nominal wage index $(2000=100)$ & 109.1 & 122.7 & 140.1 & 169.3 & 181.0 \\
\hline Percent change & 9.1 & 63.4 & 40.1 & 55.2 & 47.5 \\
\hline $\mathrm{CPI}$ index (period average, $2000=100$ ) & 109.0 & 110.1 & 113.8 & 123.2 & 138.1 \\
\hline Percent change & 8.0 & 1.1 & 3.3 & 8.3 & 12.1 \\
\hline Real wage index $(2000=100)$ & 100.1 & 111.4 & 123.1 & 137.4 & 131.0 \\
\hline Percent change & 1.0 & 11.3 & 10.5 & 11.6 & -4.7 \\
\hline Exchange rate (period average; togrogs/US\$) & $1,097.7$ & $1,110.3$ & $1,147.0$ & $1,185.2$ & 1,205 \\
\hline Monthly per capita wage (US\$) & 52.3 & 58.1 & 64.2 & 75.2 & 79.0 \\
\hline
\end{tabular}

Sources: Data provided by the National Statistical Office; and the Ministry of Finance. 
Table 18. Mongolia: Summary Operations of the General Government, 2002-06

\begin{tabular}{|c|c|c|c|c|c|c|}
\hline & \multirow[t]{2}{*}{2002} & \multirow[t]{2}{*}{2003} & \multirow[t]{2}{*}{2004} & \multirow[t]{2}{*}{2005} & \multicolumn{2}{|l|}{2006} \\
\hline & & & & & $\begin{array}{r}\text { Amended } \\
\text { Budget }\end{array}$ & Est. \\
\hline & \multicolumn{6}{|c|}{ (In billions of togrogs) } \\
\hline Total revenue and grants & 477.0 & 553.9 & 713.1 & 837.9 & $1,097.6$ & $1,343.4$ \\
\hline Total expenditure and net lending & 550.5 & 615.8 & 753.7 & 764.6 & $1,209.2$ & $1,046.5$ \\
\hline Overall balance (incl. grants) & -73.4 & -61.9 & -40.6 & 73.3 & -111.6 & 296.8 \\
\hline Nonmineral overall balance & -96.2 & -103.1 & -120.4 & -37.9 & -367.9 & -149.3 \\
\hline Financing & 70.9 & 51.1 & 33.8 & 3.5 & 111.6 & -296.8 \\
\hline Foreign (net) & 81.8 & -115.8 & 81.0 & 89.8 & 148.8 & 87.1 \\
\hline \multirow[t]{2}{*}{ Domestic (net) } & -10.9 & 166.9 & -47.1 & -86.2 & -37.2 & -384.0 \\
\hline & \multicolumn{6}{|c|}{ (In percent of GDP) } \\
\hline Total revenue and grants & 38.3 & 37.6 & 37.0 & 33.7 & 33.2 & 40.6 \\
\hline Current revenue & 37.7 & 37.0 & 36.7 & 33.4 & 33.0 & 40.5 \\
\hline Mineral revenue & 1.8 & 2.8 & 4.1 & 4.5 & 7.8 & 13.5 \\
\hline Nonmineral revenue & 35.9 & 34.2 & 32.5 & 29.0 & 25.3 & 27.0 \\
\hline Tax revenue and social security contributions & 28.9 & 28.6 & 30.3 & 27.8 & 26.6 & 33.8 \\
\hline Income taxes & 5.8 & 6.6 & 7.5 & 7.2 & 9.6 & 15.1 \\
\hline Enterprise income tax & 3.7 & 4.7 & 5.1 & 4.8 & 4.8 & 7.0 \\
\hline Personal income tax & 2.1 & 2.0 & 2.4 & 2.3 & 2.1 & 2.1 \\
\hline "Windfall" tax & 0.0 & 0.0 & 0.0 & 0.0 & 2.6 & 5.9 \\
\hline Social security contributions & 4.4 & 4.4 & 4.3 & 3.8 & 3.2 & 3.2 \\
\hline Sales tax and VAT & 9.5 & 8.3 & 8.5 & 7.3 & 6.3 & 6.8 \\
\hline Excise taxes & 4.1 & 4.0 & 3.6 & 3.2 & 2.7 & 2.8 \\
\hline Customs duties and export taxes & 2.0 & 2.2 & 2.3 & 2.3 & 1.7 & 2.1 \\
\hline Other taxes & 3.0 & 3.1 & 4.1 & 4.1 & 3.2 & 3.9 \\
\hline Nontax revenue & 8.9 & 8.4 & 6.4 & 5.6 & 6.4 & 6.6 \\
\hline Capital revenue and grants & 0.6 & 0.6 & 0.4 & 0.2 & 0.2 & 0.2 \\
\hline Total expenditure and net lending & 44.2 & 41.8 & 39.1 & 30.7 & 36.6 & 31.7 \\
\hline Current expenditure & 33.4 & 29.5 & 28.0 & 24.1 & 26.5 & 24.1 \\
\hline Wages and salaries & 8.4 & 7.9 & 7.2 & 6.2 & 6.0 & 5.9 \\
\hline Purchase of goods and services & 14.5 & 11.9 & 11.3 & 9.3 & 11.7 & 9.4 \\
\hline Subsidies to public enterprises & 0.7 & 0.6 & 0.6 & 0.3 & 0.4 & 0.4 \\
\hline Transfers & 8.1 & 7.9 & 7.7 & 7.4 & 7.7 & 7.8 \\
\hline Interest payments & 1.6 & 1.2 & 1.2 & 0.8 & 0.8 & 0.6 \\
\hline Contingency allocation & $\ldots$ & $\ldots$ & $\ldots$ & 0.0 & 0.0 & 0.0 \\
\hline Capital expenditure and net lending & 10.9 & 12.3 & 11.1 & 6.6 & 10.0 & 7.6 \\
\hline Capital expenditure & 5.5 & 6.1 & 5.4 & 3.6 & 6.3 & 5.4 \\
\hline Domestically-financed & 4.2 & 4.6 & 4.3 & 3.2 & 5.0 & 5.1 \\
\hline Foreign-financed & 1.3 & 1.6 & 1.2 & 0.4 & 1.3 & 0.3 \\
\hline Net lending & 5.4 & 6.1 & 5.7 & 3.0 & 3.7 & 2.2 \\
\hline On-lent foreign project loans & 5.3 & 5.7 & 5.5 & 3.6 & 4.2 & 2.7 \\
\hline Domestic lending minus repayments & 0.1 & 0.4 & 0.1 & -0.6 & -0.5 & -0.5 \\
\hline Current balance (excl. privatization receipts) & 4.4 & 7.5 & 8.6 & 9.3 & 6.5 & 16.4 \\
\hline Primary Balance & -4.3 & -3.0 & -0.9 & 3.8 & -2.6 & 9.6 \\
\hline Overall balance (incl. grants) & -5.9 & -4.2 & -2.1 & 2.9 & -3.4 & 9.0 \\
\hline Nonmineral overall balance & -7.7 & -7.0 & -6.3 & -1.5 & -11.1 & -4.5 \\
\hline Discrepancy between deficit from above and below the line & -0.2 & -0.7 & -0.3 & 0.8 & 0.0 & 0.0 \\
\hline Financing & 5.7 & 3.5 & 1.8 & -2.1 & 3.4 & -9.0 \\
\hline Foreign (net) & 6.6 & -7.9 & 4.2 & 3.6 & 4.5 & 2.6 \\
\hline External borrowing (net) & 6.6 & -7.9 & 3.5 & 3.4 & 4.5 & 2.6 \\
\hline Disbursements & 7.8 & 13.1 & 4.9 & 4.4 & 5.8 & 3.3 \\
\hline Amortization & 1.2 & 20.9 & 1.4 & 1.0 & 1.3 & 0.7 \\
\hline External arrears & 0.0 & 0.0 & 0.7 & 0.2 & 0.0 & 0.0 \\
\hline Domestic (net) & -0.9 & 11.3 & -2.4 & -5.7 & -1.1 & -11.6 \\
\hline Banking system (net) & -2.2 & 9.4 & -3.2 & -5.8 & -1.6 & -12.1 \\
\hline Nonbank & 1.4 & 1.9 & 0.8 & 0.0 & 0.5 & 0.5 \\
\hline Privatization receipts & 1.4 & 1.5 & 0.8 & 0.2 & 0.5 & 0.5 \\
\hline Other nonbank (net) & 0.0 & 0.5 & -0.1 & -0.2 & 0.0 & 0.0 \\
\hline Memoranda items: & \multicolumn{6}{|c|}{ (In percent of GDP; unless otherwise indicated) } \\
\hline Mineral revenue/total revenue and grants (in percent) & 4.8 & 7.4 & 11.2 & 13.3 & 23.4 & 33.2 \\
\hline Nonmineral overall balance $1 /$ & -8.6 & -8.0 & -7.7 & -2.0 & -16.3 & -6.6 \\
\hline Nonmineral primary balance $1 /$ & -6.8 & -6.6 & -6.2 & -0.9 & -15.1 & -5.7 \\
\hline Total public debt (incl. IMF)/GDP & 91.4 & 113.0 & 93.0 & 68.3 & 55.4 & 53.6 \\
\hline Foreign debt (incl. IMF)/GDP & 88.4 & 98.2 & 85.4 & 64.1 & 52.8 & 51.0 \\
\hline Domestic debt/GDP & 3.0 & 14.8 & 7.6 & 4.2 & 2.6 & 2.6 \\
\hline Governments deposits & 5.1 & 7.8 & 5.0 & 5.9 & 5.3 & 16.0 \\
\hline Net public debt & 86.3 & 105.2 & 88.0 & 62.4 & 50.1 & 37.6 \\
\hline NPV of total public debt & 62.5 & 79.5 & 59.9 & 44.7 & 35.7 & 34.6 \\
\hline Nominal GDP & $1,244.9$ & 1,474 & 1,926 & 2,489 & 3,306 & 3,306 \\
\hline
\end{tabular}

Sources: Data provided by the Ministry of Finance; and Fund staff estimates.

$1 /$ In percent of nonmineral GDP 
Table 19. Mongolia: General Government Revenue, 2001-05

\begin{tabular}{|c|c|c|c|c|c|}
\hline & 2001 & 2002 & 2003 & 2004 & 2005 \\
\hline & \multicolumn{5}{|c|}{ (In billions of togrogs) } \\
\hline Total revenue and grants & 429.5 & 477.0 & 553.9 & 713.1 & 837.9 \\
\hline Current revenue & 420.1 & 469.7 & 545.2 & 706.3 & 832.6 \\
\hline Tax revenue and social security contributions & 328.2 & 359.2 & 421.0 & 583.1 & 692.2 \\
\hline Income taxes & 64.5 & 72.4 & 97.6 & 144.1 & 178.5 \\
\hline Enterprise income tax & 43.8 & 46.3 & 68.8 & 98.6 & 120.6 \\
\hline of which Erdenet & 11.3 & 9.5 & 29.8 & 52.9 & 61.3 \\
\hline Personal income tax & 20.7 & 26.2 & 28.8 & 45.5 & 58.0 \\
\hline Social security contributions & 54.0 & 54.4 & 65.2 & 82.1 & 95.6 \\
\hline Sales tax and VAT & 104.2 & 118.7 & 121.9 & 163.1 & 181.0 \\
\hline Domestic VAT (Sales tax prior to 1998) & 43.8 & 40.7 & 47.9 & 57.4 & 70.6 \\
\hline VAT on imports (Sales tax prior to 1998) & 60.4 & 78.0 & 94.3 & 136.9 & 157.5 \\
\hline Excise taxes & 53.3 & 51.3 & 58.6 & 70.3 & 79.0 \\
\hline Excise on alcohol & 23.2 & 20.6 & 19.8 & 23.3 & 26.1 \\
\hline Excise on vodka and tobacco & 3.1 & 3.5 & 3.7 & 4.2 & 6.3 \\
\hline Excise on imported beer & 3.1 & 2.9 & 3.3 & 3.3 & 2.0 \\
\hline Excise on vehicles & 7.3 & 6.0 & 10.5 & 14.7 & 16.7 \\
\hline Excise on petroleum & 16.6 & 18.3 & 21.3 & 24.8 & 25.2 \\
\hline Customs duties and export taxes & 27.0 & 24.6 & 32.6 & 44.7 & 57.0 \\
\hline Customs duties & 26.0 & 23.8 & 31.1 & 40.8 & 53.2 \\
\hline Export taxes & 1.0 & 0.8 & 1.6 & 3.9 & 3.8 \\
\hline Other taxes & 25.2 & 37.7 & 45.1 & 78.8 & 101.1 \\
\hline Petrol and diesel tax & 5.5 & 4.9 & 5.7 & 6.1 & 5.9 \\
\hline Vehicle license fee & 3.4 & 3.7 & 4.0 & 4.8 & 5.1 \\
\hline Tax on private property & 1.7 & 3.4 & 4.6 & 5.7 & 6.3 \\
\hline Other & 14.6 & 25.8 & 30.8 & 62.1 & 83.8 \\
\hline Nontax revenue & 91.9 & 110.6 & 124.3 & 123.2 & 140.4 \\
\hline Interest and fines & 9.1 & 9.1 & 17.6 & 20.5 & 14.5 \\
\hline Own budget revenues & 47.2 & 48.0 & 65.0 & 65.2 & 68.8 \\
\hline Dividends & 11.6 & 6.4 & 1.3 & 4.1 & 22.8 \\
\hline of which: Erdenet & 1.6 & 2.5 & 0.1 & 1.9 & 18.1 \\
\hline Other nontax revenue & 24.2 & 47.2 & 40.4 & 33.4 & 34.3 \\
\hline Capital revenue and grants & 9.3 & 7.3 & 8.7 & 6.8 & 5.3 \\
\hline Capital revenue & 0.2 & 0.5 & 0.0 & 0.8 & 1.0 \\
\hline \multirow[t]{2}{*}{ Grants 1/ } & 9.2 & 6.8 & 8.7 & 6.1 & 4.3 \\
\hline & \multicolumn{5}{|c|}{ (In percent of total revenue) } \\
\hline Current revenue & 97.8 & 98.5 & 98.4 & 99.0 & 99.4 \\
\hline Tax revenue and social security contributions & 76.4 & 75.3 & 76.0 & 81.8 & 82.6 \\
\hline Enterprise income tax & 10.2 & 9.7 & 12.4 & 13.8 & 14.4 \\
\hline Personal income tax & 4.8 & 5.5 & 5.2 & 6.4 & 6.9 \\
\hline Social security contributions & 12.6 & 11.4 & 11.8 & 11.5 & 11.4 \\
\hline Taxes on goods and services & 36.7 & 35.6 & 32.6 & 32.7 & 31.0 \\
\hline Customs duties and import surcharges & 6.3 & 5.2 & 5.9 & 6.3 & 6.8 \\
\hline Other taxes & 5.9 & 7.9 & 8.1 & 11.1 & 12.1 \\
\hline Nontax revenue & 21.4 & 23.2 & 22.4 & 17.3 & 16.8 \\
\hline Capital revenue & 0.0 & 0.1 & 0.0 & 0.1 & 0.1 \\
\hline \multirow[t]{2}{*}{ Grants } & 2.1 & 1.4 & 1.6 & 0.8 & 0.5 \\
\hline & \multicolumn{5}{|c|}{ (In percent of GDP) } \\
\hline Total revenue & 38.4 & 38.3 & 37.6 & 37.0 & 33.7 \\
\hline Current revenue & 37.6 & 37.7 & 37.0 & 36.7 & 33.4 \\
\hline Tax revenue and social security contributions & 29.4 & 28.9 & 28.6 & 30.3 & 27.8 \\
\hline Enterprise income tax & 3.9 & 3.7 & 4.7 & 5.1 & 4.8 \\
\hline Personal income tax & 1.9 & 2.1 & 2.0 & 2.4 & 2.3 \\
\hline Social security contributions & 4.8 & 4.4 & 4.4 & 4.3 & 3.8 \\
\hline Taxes on goods and services & 14.1 & 13.7 & 12.2 & 12.1 & 10.4 \\
\hline Customs duties and import surcharges & 2.4 & 2.0 & 2.2 & 2.3 & 2.3 \\
\hline Other taxes & 2.3 & 3.0 & 3.1 & 4.1 & 4.1 \\
\hline Nontax revenue & 8.2 & 8.9 & 8.4 & 6.4 & 5.6 \\
\hline Capital revenue & 0.0 & 0.0 & 0.0 & 0.0 & 0.0 \\
\hline Grants & 0.8 & 0.5 & 0.6 & 0.3 & 0.2 \\
\hline
\end{tabular}

Sources: Data provided by the Ministry of Finance; and Fund staff estimates.

1/ Grants relate to receipt of the budget of counterpart funds from recipient of the grants. This differs from the balance of payments definition which records grants when they are received from abroad. 
Table 20. Mongolia: General Government Expenditure, 2001-05

\begin{tabular}{|c|c|c|c|c|c|}
\hline & 2001 & 2002 & 2003 & 2004 & 2005 \\
\hline & \multicolumn{5}{|c|}{ (In billions of togrogs) } \\
\hline Total expenditure and net lending & 489.7 & 550.5 & 615.8 & 753.7 & 764.6 \\
\hline Current expenditure & 366.7 & 415.3 & 434.8 & 539.9 & 600.3 \\
\hline Wages and salaries & 92.1 & 105.0 & 116.9 & 138.7 & 155.4 \\
\hline Goods and services & 162.6 & 180.8 & 174.9 & 217.5 & 231.3 \\
\hline Subsidies and current transfers & 95.5 & 109.9 & 125.4 & 160.5 & 192.9 \\
\hline Subsidies 1/ & 6.1 & 8.8 & 9.4 & 11.4 & 8.1 \\
\hline Transfers & 89.4 & 101.1 & 116.0 & 149.1 & 184.8 \\
\hline Social Security Fund & 64.3 & 73.3 & 87.5 & 116.2 & 132.0 \\
\hline Social Assistance Fund & 13.7 & 17.4 & 19.8 & 23.0 & 41.7 \\
\hline Other transfers & 11.4 & 10.5 & 8.7 & 9.8 & 11.0 \\
\hline Interest payment & 16.5 & 19.6 & 17.6 & 23.2 & 20.7 \\
\hline Capital expenditure and net lending & 123.0 & 135.2 & 180.9 & 213.8 & 164.3 \\
\hline Domestically financed capital expenditu & 49.0 & 52.3 & 67.2 & 82.7 & 79.4 \\
\hline Domestic lending minus repayment & 5.3 & 0.7 & 6.1 & 2.8 & -14.2 \\
\hline \multirow[t]{2}{*}{ Foreign financed projects } & 68.8 & 82.2 & 107.6 & 128.3 & 99.1 \\
\hline & \multicolumn{5}{|c|}{ (In percent of total expenditure) } \\
\hline Current expenditure & 74.9 & 75.4 & 70.6 & 71.6 & 78.5 \\
\hline Wages and salaries & 18.8 & 19.1 & 19.0 & 18.4 & 20.3 \\
\hline Goods and services & 33.2 & 32.8 & 28.4 & 28.9 & 30.2 \\
\hline Subsidies and transfers & 19.5 & 20.0 & 20.4 & 21.3 & 25.2 \\
\hline Subsidies & 1.2 & 1.6 & 1.5 & 1.5 & 1.1 \\
\hline Transfers and other & 18.3 & 18.4 & 18.8 & 19.8 & 24.2 \\
\hline Social Security Fund & 13.1 & 13.3 & 14.2 & 15.4 & 17.3 \\
\hline Other & 5.1 & 5.1 & 4.6 & 3.1 & 6.9 \\
\hline Interest payments & 3.4 & 3.6 & 2.9 & 3.1 & 2.7 \\
\hline Capital expenditure and net lending & 25.1 & 24.6 & 29.4 & 28.4 & 21.5 \\
\hline Domestically financed capital expenditu & 10.0 & 9.5 & 10.9 & 11.0 & 10.4 \\
\hline Domestic lending minus repayment & 1.1 & 0.1 & 1.0 & 0.4 & -1.9 \\
\hline Foreign financed projects & 14.0 & 14.9 & 17.5 & 17.0 & 13.0 \\
\hline Total expenditure and net lending & 43.8 & 44.2 & 41.8 & 39.1 & 30.7 \\
\hline Current expenditure & 32.8 & 33.4 & 29.5 & 28.0 & 24.1 \\
\hline Wages and salaries & 8.2 & 8.4 & 7.9 & 7.2 & 6.2 \\
\hline Goods and services & 14.6 & 14.5 & 11.9 & 11.3 & 9.3 \\
\hline Subsidies and current transfers & 8.5 & 8.8 & 8.5 & 8.3 & 7.7 \\
\hline Subsidies & 0.5 & 0.7 & 0.6 & 0.6 & 0.3 \\
\hline Transfers & 8.0 & 8.1 & 7.9 & 7.7 & 7.4 \\
\hline Social Security Fund & 5.8 & 5.9 & 5.9 & 6.0 & 5.3 \\
\hline Social Assistance Fund & 1.2 & 1.4 & 1.3 & 1.2 & 1.7 \\
\hline Other transfers & 1.0 & 0.8 & 0.6 & 0.0 & 0.4 \\
\hline Interest payment & 1.5 & 1.6 & 1.2 & 1.2 & 0.8 \\
\hline Capital expenditure and net lending & 11.0 & 10.9 & 12.3 & 11.1 & 6.6 \\
\hline Domestically financed capital expenditu & 4.4 & 4.2 & 4.6 & 4.3 & 3.2 \\
\hline Domestic lending minus repayment & 0.5 & 0.1 & 0.4 & 0.1 & -0.6 \\
\hline Foreign financed projects & 6.2 & 6.6 & 7.3 & 6.7 & 4.0 \\
\hline
\end{tabular}

Sources: Data provided by the Ministry of Finance; and Fund staff estimates.

1/ Beginning in 2001, this item includes subsidies to state-owned enterprises for quasi-fiscal activities which, previously, had been recorded under purchases of goods and services. 
Table 21. Mongolia: General Government Expenditure by Function, 2001-06

\begin{tabular}{|c|c|c|c|c|c|c|}
\hline & 2001 & 2002 & 2003 & 2004 & 2005 & Budget \\
\hline & \multicolumn{6}{|c|}{ (In billions of togrogs) } \\
\hline Total expenditure & 489.7 & 550.5 & 615.8 & 753.6 & 764.6 & $1,209.1$ \\
\hline General public services & 50.4 & 54.0 & 53.7 & 63.7 & 69.2 & 112.9 \\
\hline Defense & 25.4 & 28.1 & 27.9 & 32.9 & 35.9 & 44.8 \\
\hline Public order and safety & 28.7 & 30.5 & 33.4 & 44.2 & 49.8 & 60.1 \\
\hline Education & 98.7 & 103.7 & 115.4 & 141.0 & 147.8 & 192.3 \\
\hline Health & 54.3 & 58.0 & 58.1 & 73.2 & 80.2 & 99.9 \\
\hline Social security and welfare & 84.5 & 96.9 & 117.6 & 150.6 & 185.7 & 251.5 \\
\hline Housing and community services & 7.1 & 7.6 & 6.3 & 9.6 & 7.9 & 5.5 \\
\hline Recreation and culture & 15.1 & 17.5 & 18.2 & 21.5 & 20.8 & 23.4 \\
\hline Economic affairs & 45.1 & 58.9 & 73.5 & 84.9 & 85.1 & 257.3 \\
\hline \multirow[t]{2}{*}{ Other $1 /$} & 80.4 & 95.3 & 111.7 & 132.0 & 82.2 & 161.4 \\
\hline & \multicolumn{6}{|c|}{ (In percent of total expenditure) } \\
\hline General public services & 10.3 & 9.8 & 8.7 & 8.5 & 9.1 & 9.3 \\
\hline Defense & 5.2 & 5.1 & 4.5 & 4.4 & 4.7 & 3.7 \\
\hline Public order and safety & 5.9 & 5.5 & 5.4 & 5.9 & 6.5 & 5.0 \\
\hline Education & 20.2 & 18.8 & 18.7 & 18.7 & 19.3 & 15.9 \\
\hline Health & 11.1 & 10.5 & 9.4 & 9.7 & 10.5 & 8.3 \\
\hline Social security and welfare & 17.3 & 17.6 & 19.1 & 20.0 & 24.3 & 20.8 \\
\hline Housing and community services & 1.4 & 1.4 & 1.0 & 1.3 & 1.0 & 0.5 \\
\hline Recreation and culture & 3.1 & 3.2 & 3.0 & 2.9 & 2.7 & 1.9 \\
\hline Economic affairs & 9.2 & 10.7 & 11.9 & 11.3 & 11.1 & 21.3 \\
\hline \multirow[t]{2}{*}{ Other $1 /$} & 16.4 & 17.3 & 18.1 & 17.5 & 10.8 & 13.3 \\
\hline & \multicolumn{6}{|c|}{ (In percent of GDP) } \\
\hline Total expenditure & 43.8 & 44.2 & 41.8 & 39.1 & 30.7 & 36.6 \\
\hline General public services & 4.5 & 4.3 & 3.6 & 3.3 & 2.8 & 3.4 \\
\hline Defense & 2.3 & 2.3 & 1.9 & 1.7 & 1.4 & 1.4 \\
\hline Public order and safety & 2.6 & 2.4 & 2.3 & 2.3 & 2.0 & 1.8 \\
\hline Education & 8.8 & 8.3 & 7.8 & 7.3 & 5.9 & 5.8 \\
\hline Health & 4.9 & 4.7 & 3.9 & 3.8 & 3.2 & 3.0 \\
\hline Social security and welfare & 7.6 & 7.8 & 8.0 & 7.8 & 7.5 & 7.6 \\
\hline Housing and community services & 0.6 & 0.6 & 0.4 & 0.5 & 0.3 & 0.2 \\
\hline Recreation and culture & 1.4 & 1.4 & 1.2 & 1.1 & 0.8 & 0.7 \\
\hline Economic affairs & 4.0 & 4.7 & 5.0 & 4.4 & 3.4 & 7.8 \\
\hline Other $1 /$ & 7.2 & 7.7 & 7.6 & 6.9 & 3.3 & 4.9 \\
\hline
\end{tabular}

Sources: Data provided by the Ministry of Finance; and Fund staff estimates.

1/ Includes capital expenditure and net lending (foreign-financed projects). 
Table 22. Mongolia: General Government Social Expenditure, 2001-06

\begin{tabular}{|c|c|c|c|c|c|c|}
\hline & 2001 & 2002 & 2003 & 2004 & 2005 & $\frac{2006}{\text { Budget }}$ \\
\hline & \multicolumn{6}{|c|}{ (In billions of togrogs) } \\
\hline Total expenditure & 489.7 & 550.5 & 615.8 & 753.6 & 764.6 & $1,209.1$ \\
\hline Social expenditure & 259.7 & 283.7 & 315.6 & 395.9 & 442.2 & 572.6 \\
\hline Social security and social assistance & 84.5 & 96.9 & 117.6 & 150.6 & 185.6 & 251.5 \\
\hline Education & 98.7 & 103.7 & 115.4 & 141.0 & 147.8 & 192.3 \\
\hline Health & 54.3 & 58.0 & 58.1 & 73.2 & 80.1 & 99.9 \\
\hline Housing and community services & 7.1 & 7.6 & 6.3 & 9.6 & 7.9 & 5.5 \\
\hline \multirow[t]{2}{*}{ Recreational, cultural affairs and services } & 15.1 & 17.5 & 18.2 & 21.5 & 20.8 & 23.4 \\
\hline & \multicolumn{6}{|c|}{ (In percent of total expenditure) } \\
\hline Social expenditure & 53.0 & 51.5 & 51.3 & 52.5 & 57.8 & 47.4 \\
\hline Social security and social assistance & 17.3 & 17.6 & 19.1 & 20.0 & 24.3 & 20.8 \\
\hline Education & 20.2 & 18.8 & 18.7 & 18.7 & 19.3 & 15.9 \\
\hline Health & 11.1 & 10.5 & 9.4 & 9.7 & 10.5 & 8.3 \\
\hline Housing and community & 1.4 & 1.4 & 1.0 & 1.3 & 1.0 & 0.5 \\
\hline Recreational, cultural affairs and services & 3.1 & 3.2 & 3.0 & 2.9 & 2.7 & 1.9 \\
\hline
\end{tabular}

Sources: Data provided by the Ministry of Finance; and Fund staff estimates. 
Table 23. Mongolia: Subsidies and Transfers, 2001-06

\begin{tabular}{|c|c|c|c|c|c|c|}
\hline & 2001 & 2002 & 2003 & 2004 & 2005 & $\frac{2006}{\text { Budget }}$ \\
\hline & \multicolumn{6}{|c|}{ (In billions of togrogs) } \\
\hline Total subsidies and transfers & 95.5 & 109.9 & 125.4 & 160.4 & 195.7 & 267.1 \\
\hline Total subsidies & 6.0 & 8.8 & 9.4 & 11.3 & 11.0 & 12.9 \\
\hline Energy & 5.4 & 8.6 & 7.9 & 8.1 & 4.4 & 7.4 \\
\hline Urban transport & 0.5 & 0.0 & 1.5 & 3.2 & 3.7 & 5.5 \\
\hline Other & 0.1 & 0.1 & 0.0 & 0.0 & 2.9 & 4.8 \\
\hline Total transfers & 89.4 & 101.1 & 116.0 & 149.1 & 184.7 & 254.2 \\
\hline Social Security Fund & 64.3 & 73.3 & 87.5 & 116.2 & 132.0 & 170.2 \\
\hline Social Assistance Fund & 13.7 & 17.4 & 19.8 & 23.0 & 41.7 & 73.1 \\
\hline \multirow[t]{2}{*}{ Other } & 11.4 & 10.5 & 8.7 & 9.8 & 11.0 & 10.9 \\
\hline & \multicolumn{6}{|c|}{ (In percent of GDP) } \\
\hline Total subsidies and transfers & 8.5 & 8.8 & 8.5 & 8.3 & 7.9 & 8.1 \\
\hline Total subsidies & 0.5 & 0.7 & 0.6 & 0.6 & 0.4 & 0.4 \\
\hline Total transfers & 8.0 & 8.1 & 7.9 & 7.7 & 7.4 & 7.7 \\
\hline
\end{tabular}

Sources: Data provided by the Ministry of Finance; and Fund staff estimates. 
Table 24. Mongolia: Social Security and Social Assistance Funds, 2001-06

\begin{tabular}{|c|c|c|c|c|c|c|}
\hline & 2001 & 2002 & 2003 & 2004 & 2005 & $\underline{2006}$ \\
\hline & \multicolumn{6}{|c|}{ (In billions of togrogs) } \\
\hline \multicolumn{7}{|l|}{ Social Security Fund } \\
\hline Total revenue & 73.9 & 83.6 & 94.6 & 115.3 & 132.1 & 160.1 \\
\hline Budget transfers & 21.0 & 24.4 & 24.4 & 42.0 & 44.2 & 61.0 \\
\hline Social security contributions $1 /$ & 67.0 & 76.5 & 84.9 & 107.2 & 123.7 & 148.4 \\
\hline Civil servants & 21.4 & 23.4 & 25.5 & 28.2 & 31.5 & 50.7 \\
\hline Business entities & 28.1 & 27.8 & 36.0 & 43.5 & 51.7 & 61.4 \\
\hline Employees & 23.8 & 25.4 & 24.4 & 35.5 & 40.5 & 36.3 \\
\hline Other & 2.0 & 2.2 & 4.8 & 3.1 & 3.4 & 6.6 \\
\hline Total expenditure & 64.3 & 73.3 & 87.5 & 116.2 & 132.0 & 171.0 \\
\hline Old age pension & 41.9 & 47.0 & 55.3 & 73.6 & 83.5 & 116.0 \\
\hline Handicapped persons & 6.2 & 7.5 & 9.5 & 14.3 & 16.6 & 17.8 \\
\hline Survivors' benefits & 6.7 & 7.8 & 9.0 & 12.1 & 12.9 & 15.8 \\
\hline Disability benefits & 0.9 & 1.1 & 1.3 & 1.5 & 1.6 & 1.4 \\
\hline Death benefits & 1.2 & 1.6 & 1.8 & 1.9 & 1.9 & 2.0 \\
\hline Allowance for accidents & 2.2 & 2.4 & 3.0 & 4.0 & 4.5 & 5.3 \\
\hline Serviceman's pension & 3.8 & 4.2 & 5.3 & 6.6 & 7.8 & 8.6 \\
\hline Unemployment benefits & 0.5 & 0.6 & 1.1 & 1.0 & 1.1 & 1.0 \\
\hline Other & 0.9 & 1.0 & 1.2 & 1.3 & 2.0 & 3.1 \\
\hline Overall balance & 8.0 & 9.2 & 8.8 & 12.0 & 13.0 & 19.0 \\
\hline \multicolumn{7}{|l|}{ Social Assistance Fund } \\
\hline Total expenditure & 13.7 & 17.3 & 19.8 & 23.2 & 41.7 & 73.0 \\
\hline Pregnancy & 3.6 & 4.3 & 4.2 & 4.3 & 4.1 & 4.3 \\
\hline Mothers with large families & 0.5 & 0.7 & 0.8 & 0.8 & 0.0 & 0.0 \\
\hline Child care & 0.1 & 0.1 & 0.1 & 0.2 & 0.1 & 0.1 \\
\hline Twins & 0.0 & 0.0 & 0.0 & 0.0 & 0.1 & 0.1 \\
\hline Infant nursing & 3.3 & 4.3 & 4.8 & 5.7 & 5.7 & 7.4 \\
\hline Social pension & 3.8 & 4.4 & 5.7 & 7.1 & 7.6 & 10.4 \\
\hline War veterans & 1.6 & 2.2 & 2.4 & 3.0 & 3.5 & 2.1 \\
\hline Other & 0.8 & 1.4 & 1.7 & 2.1 & 20.6 & 48.6 \\
\hline & \multicolumn{6}{|c|}{ (In percent of total government expenditure) } \\
\hline \multicolumn{7}{|l|}{ Memoranda items: } \\
\hline Social Security Fund expenditure & 13.4 & 13.3 & 14.2 & 15.4 & 17.6 & 16.1 \\
\hline Budget transfers to the Social Security Fund & 4.3 & 4.4 & 4.0 & 5.6 & 5.9 & 5.7 \\
\hline Social Assistance Fund expenditure & 2.8 & 3.2 & 3.2 & 3.1 & 5.5 & 6.9 \\
\hline & \multicolumn{6}{|c|}{ (In percent of GDP) } \\
\hline Social Security Fund expenditure & 5.8 & 5.9 & 5.9 & 6.0 & 5.3 & 5.2 \\
\hline Budget transfers to the Social Security Fund & 1.9 & 2.0 & 1.7 & 2.2 & 1.8 & 1.8 \\
\hline Social Assistance Fund expenditure & 1.2 & 1.4 & 1.3 & 1.2 & 1.7 & 2.2 \\
\hline
\end{tabular}

Sources: Data provided by the Ministry of Finance; and Fund staff estimates.

1/ A part of social security contributions constitutes intergovernmental transfers. 
Table 25. Mongolia: Number of Social Security Beneficiaries, 2001-06

(In thousands)

\begin{tabular}{|c|c|c|c|c|c|c|}
\hline & 2001 & 2002 & 2003 & 2004 & 2005 & $\underline{2006}$ \\
\hline Social security & 316.5 & 344.1 & 364.0 & 365.5 & 379.7 & 391.5 \\
\hline Old age & 173.2 & 173.0 & 175.9 & 176.3 & 190.9 & 193.8 \\
\hline Handicapped persons & 35.2 & 42.7 & 41.6 & 52.7 & 49.8 & 53.2 \\
\hline Survivors' benefits & 35.6 & 36.7 & 37.7 & 37.8 & 36.0 & 36.3 \\
\hline Disability benefits & 62.9 & 54.8 & 64.3 & 58.1 & 61.3 & 60.0 \\
\hline Other benefits & 9.6 & 37.0 & 44.6 & 40.5 & 41.7 & 48.2 \\
\hline Social assistance & 242.2 & 285.1 & 354.1 & 378.7 & 341.6 & 237.7 \\
\hline Pregnancy & 50.5 & 49.3 & 51.5 & 54.5 & 45.5 & 43.8 \\
\hline Mothers with large families & 53.8 & 17.5 & 35.7 & 33.5 & 56.7 & 33.7 \\
\hline Child care & 20.6 & 4.6 & 5.9 & 7.5 & 6.7 & 5.8 \\
\hline Twins & 0.3 & 0.3 & 0.3 & 0.3 & 0.3 & 0.3 \\
\hline Infant nursing & 3.3 & 57.1 & 58.4 & 59.1 & 56.7 & 50.0 \\
\hline War veterans & 56.2 & 86.5 & 107.1 & 125.2 & 111.5 & 51.4 \\
\hline Social pension & 33.8 & 37.3 & 39.7 & 43.6 & 41.8 & 43.8 \\
\hline Disabled Nursing homes for elderly & 10.1 & 15.5 & 19.3 & 27.9 & 22.4 & 8.9 \\
\hline Other & 13.6 & 16.8 & 36.2 & 27.1 & & \\
\hline
\end{tabular}

Source: Data provided by the Ministry of Finance. 
Table 26. Mongolia: Government Employment and Wage Bill, 2001-06

\begin{tabular}{|c|c|c|c|c|c|c|}
\hline & 2001 & 2002 & 2003 & 2004 & 2005 & $\begin{array}{r}2006 \\
\text { Budget }\end{array}$ \\
\hline & \multicolumn{6}{|c|}{ (Number of positions) } \\
\hline \multicolumn{7}{|l|}{ Government employment } \\
\hline General public services & 15,543 & 16,114 & 14,744 & 13,807 & 5,871 & 5,681 \\
\hline Public order and safety & 12,658 & 12,186 & 14,506 & 9,569 & 15,055 & 15,095 \\
\hline Education & 48,866 & 50,928 & 47,927 & 48,444 & 46,070 & 46,076 \\
\hline Health & 25,344 & 25,770 & 24,643 & 23,023 & 22,323 & 22,884 \\
\hline Social security and welfare & 621 & 686 & 643 & 608 & 753 & 763 \\
\hline Recreation and culture & 6,210 & 5,923 & 5,721 & 5,174 & 0 & 83 \\
\hline Agriculture and forestry & 1,392 & 1,404 & 1,207 & 1,037 & 1,402 & 1,268 \\
\hline Other services & 22,615 & 22,582 & 22,774 & 18,833 & 24,467 & 24,297 \\
\hline Total & 133,248 & 135,591 & 132,164 & 120,493 & 115,940 & 116,146 \\
\hline & \multicolumn{6}{|c|}{ (In billions of togrogs) } \\
\hline \multicolumn{7}{|l|}{ Wages and salaries } \\
\hline General public services & 13.0 & 14.9 & 16.2 & 18.5 & 20.3 & 27.8 \\
\hline Public order and safety & 12.1 & 13.5 & 14.9 & 17.8 & 20.0 & 28.2 \\
\hline Education & 36.1 & 41.4 & 46.4 & 45.4 & 50.2 & 67.6 \\
\hline Health & 15.0 & 16.2 & 17.8 & 22.8 & 24.8 & 35.1 \\
\hline Social security and welfare & 0.3 & 0.4 & 0.4 & 0.5 & 0.7 & 1.0 \\
\hline Recreation and culture & 3.4 & 4.1 & 4.3 & 4.8 & 5.3 & 6.9 \\
\hline Agriculture and forestry & 0.5 & 0.9 & 0.8 & 0.8 & 1.2 & 1.7 \\
\hline Other services & 11.7 & 13.6 & 16.1 & 18.0 & 24.9 & 29.3 \\
\hline Total & 92.1 & 105.0 & 116.9 & 138.4 & 160.4 & 197.6 \\
\hline
\end{tabular}

Source: Data provided by the Ministry of Finance. 
Table 27. Mongolia: Expenditure of the Health Sector, 2001-06

(In billions of togrogs)

\begin{tabular}{|c|c|c|c|c|c|c|}
\hline & 2001 & 2002 & 2003 & 2004 & 2005 & $\underline{2006}$ \\
\hline Total expenditure & 54.3 & 58.0 & 58.1 & 73.1 & 79.7 & 99.8 \\
\hline Wages and salaries & 15.0 & 16.2 & 17.8 & 22.8 & 24.8 & 35.0 \\
\hline Social security & 4.3 & 4.4 & 4.8 & 5.9 & 6.5 & 9.3 \\
\hline Social security payments & 3.5 & 3.6 & 4.0 & 5.0 & 5.4 & 7.6 \\
\hline Health insurance & 0.8 & 0.8 & 0.8 & 0.9 & 1.1 & 1.7 \\
\hline Other goods and services & 33.0 & 34.5 & 32.2 & 40.8 & 44.6 & 48.3 \\
\hline Electricity & 1.6 & 1.6 & 1.7 & 1.8 & 2.0 & 2.3 \\
\hline Fuel and heating & 5.6 & 5.3 & 5.3 & 5.8 & 6.6 & 7.9 \\
\hline Transport (fuel) & 2.0 & 2.0 & 2.0 & 2.6 & 3.4 & 3.7 \\
\hline Food & 2.7 & 2.7 & 2.9 & 3.4 & 3.5 & 3.7 \\
\hline Medicines & 9.5 & 9.1 & 10.0 & 12.0 & 12.5 & 12.7 \\
\hline Other & 11.7 & 13.8 & 10.3 & 15.2 & 16.6 & 18.0 \\
\hline Investment & 1.3 & 2.0 & 2.3 & 2.4 & 2.3 & 5.8 \\
\hline Capital repair expenditures & 0.7 & 0.9 & 1.1 & 1.1 & 1.0 & 0.8 \\
\hline
\end{tabular}

Source: Data provided by the Ministry of Finance. 
Table 28. Mongolia: Expenditure of the Education Sector, 2001-06

(In billions of togrogs)

\begin{tabular}{|c|c|c|c|c|c|c|}
\hline & 2001 & 2002 & 2003 & 2004 & 2005 & $\frac{2006}{\text { Budget }}$ \\
\hline Total expenditure & 98.7 & 103.7 & 115.4 & 140.9 & 145.2 & 169.7 \\
\hline Wages and salaries & 36.1 & 41.4 & 46.4 & 45.4 & 50.2 & 67.6 \\
\hline Social security & 9.8 & 10.5 & 11.8 & 11.8 & 13.1 & 17.8 \\
\hline Social security payments & 8.2 & 8.7 & 9.7 & 9.7 & 10.9 & 14.6 \\
\hline Health insurance & 1.7 & 1.8 & 2.1 & 2.1 & 2.2 & 3.2 \\
\hline Other goods and services & 45.8 & 43.9 & 47.8 & 72.0 & 41.7 & 68.9 \\
\hline Electricity & 2.8 & 2.6 & 2.9 & 3.0 & 3.1 & 3.7 \\
\hline Fuel and heating & 15.4 & 14.2 & 15.5 & 17.1 & 19.9 & 23.0 \\
\hline Transport (fuel) & 0.7 & 0.7 & 0.7 & 0.9 & 0.9 & 1 \\
\hline Food & 5.4 & 5.9 & 7.7 & 9.5 & 10.6 & 13.7 \\
\hline Medicines & 0.0 & 0.0 & 0.0 & 0.0 & 7.2 & 5.6 \\
\hline Other & 21.6 & 20.4 & 21.0 & 41.4 & 30.0 & 44.9 \\
\hline Investment & 3.1 & 3.1 & 4.9 & 4.5 & 6.8 & 9.1 \\
\hline Capital repair expenditures & 0.8 & 1.8 & 1.2 & 1.6 & 1.2 & 0.1 \\
\hline Lending minus repayment & 3.1 & 3.1 & 3.2 & 5.7 & 2.2 & 6.2 \\
\hline
\end{tabular}

Source: Data provided by the Ministry of Finance. 
Table 29. Mongolia: Monetary Survey, 2001-06

\begin{tabular}{|c|c|c|c|c|c|c|c|c|c|c|c|}
\hline & \multirow{2}{*}{$\frac{2001}{\mathrm{Dec} .}$} & \multirow{2}{*}{$\frac{2002}{\text { Dec. }}$} & \multirow{2}{*}{$\frac{2003}{\mathrm{Dec} .}$} & \multirow{2}{*}{$\frac{2004}{\mathrm{Dec} .}$} & \multicolumn{4}{|c|}{2005} & \multicolumn{3}{|c|}{2006} \\
\hline & & & & & Mar. & Jun. & Sep. & $\overline{\text { Dec. }}$ & Mar. & Jun. & Sep. \\
\hline & \multicolumn{11}{|c|}{ (In billions of togrogs) } \\
\hline Broad money & 331 & 470 & 704 & 846 & 892 & 1,009 & 1,112 & 1,162 & 1,205 & 1,463 & 1,528 \\
\hline Currency & 109 & 121 & 131 & 144 & 133 & 177 & 174 & 152 & 145 & 198 & 189 \\
\hline Deposits & 222 & 349 & 572 & 703 & 760 & 832 & 937 & 1,009 & 1,061 & 1,265 & 1,339 \\
\hline Demand deposits & 47 & 67 & 81 & 78 & 81 & 101 & 99 & 117 & 130 & 130 & 142 \\
\hline Tugrik time deposits & 88 & 147 & 240 & 301 & 347 & 371 & 403 & 448 & 492 & 543 & 576 \\
\hline Forex deposits & 87 & 135 & 250 & 324 & 332 & 360 & 436 & 445 & 439 & 592 & 621 \\
\hline Net foreign assets & 220 & 308 & 232 & 283 & 330 & 376 & 480 & 544 & 555 & 791 & 945 \\
\hline Net international reserves & 227 & 322 & 278 & 294 & 342 & 388 & 488 & 551 & 564 & 782 & 942 \\
\hline Bank of Mongolia & 176 & 254 & 151 & 198 & 222 & 252 & 310 & 364 & 411 & 449 & 595 \\
\hline Commercial banks & 51 & 68 & 128 & 96 & 120 & 136 & 178 & 187 & 153 & 333 & 347 \\
\hline Other NFA & -7 & -13 & -47 & -11 & -12 & -12 & -8 & -7 & -9 & 10 & 3 \\
\hline Bank of Mongolia & 0 & 0 & 0 & 1 & 1 & 1 & 5 & 8 & 4 & 20 & 14 \\
\hline Commercial banks & -7 & -13 & -47 & -13 & -13 & -13 & -12 & -15 & -13 & -10 & -11 \\
\hline Net domestic assets & 111 & 162 & 472 & 564 & 562 & 633 & 632 & 618 & 650 & 672 & 583 \\
\hline Domestic credit & 170 & 243 & 601 & 740 & 747 & 804 & 828 & 904 & 946 & 983 & 910 \\
\hline Net credit to government & 31 & 7 & 152 & 94 & 65 & 48 & 7 & -1 & -50 & -121 & -267 \\
\hline Credit & 84 & 71 & 266 & 190 & 180 & 162 & 159 & 146 & 135 & 134 & 114 \\
\hline Minus: Deposits & 53 & 63 & 114 & 96 & 115 & 114 & 152 & 146 & 185 & 255 & 381 \\
\hline Claims on nonbanks & 139 & 236 & 449 & 646 & 682 & 756 & 821 & 905 & 996 & 1,103 & 1,177 \\
\hline Claims on public enterprises & 10 & 12 & 16 & 13 & 14 & 22 & 21 & 34 & 29 & 30 & 33 \\
\hline Claims on the private sector & 115 & 204 & 390 & 552 & 581 & 646 & 701 & 776 & 858 & 966 & 1,011 \\
\hline Nonperforming loans & 11 & 17 & 37 & 71 & 76 & 76 & 82 & 79 & 90 & 89 & 110 \\
\hline Accrued interest receivable on loan & 2 & 4 & 7 & 11 & 11 & 12 & 17 & 16 & 19 & 19 & 23 \\
\hline Other items, net & -59 & -82 & -129 & -176 & -185 & -171 & -197 & -286 & -296 & -311 & -326 \\
\hline \multicolumn{12}{|l|}{ Memoranda items: } \\
\hline & \multicolumn{11}{|c|}{ (12-month percentage changes) } \\
\hline Broad money $1 /$ & 28.0 & 41.9 & 49.7 & 20.3 & 20.6 & 24.3 & 34.4 & 37.3 & 35.1 & 45.0 & 37.4 \\
\hline Net foreign assets & 8.9 & 40.1 & -24.9 & 22.0 & 36.6 & 55.6 & 80.5 & 92.4 & 68.1 & 110.4 & 96.8 \\
\hline Domestic credit & 41.6 & 43.2 & 147.0 & 23.0 & 16.8 & 18.1 & 17.0 & 22.3 & 26.6 & 22.1 & 9.8 \\
\hline Claims on public enterprises & 65.8 & 17.1 & 32.8 & -22.5 & -12.8 & 55.9 & 62.7 & 171.6 & 114.8 & 33.6 & 54.1 \\
\hline \multirow[t]{2}{*}{ Claims on the private sector } & 152.4 & 77.4 & 91.3 & 41.6 & 31.7 & 30.4 & 37.3 & 40.6 & 47.6 & 49.6 & 44.1 \\
\hline & \multicolumn{11}{|c|}{ (Key ratios) } \\
\hline Currency/total deposits & 49.1 & 34.6 & 23.0 & 20.4 & 17.5 & 21.2 & 18.6 & 15.1 & 13.7 & 15.7 & 14.1 \\
\hline Demand deposits/total deposits & 21.1 & 19.2 & 14.2 & 11.1 & 10.6 & 12.1 & 10.6 & 11.6 & 12.2 & 10.3 & 10.6 \\
\hline Tugrik time deposit/total deposits & 39.6 & 42.1 & 42.0 & 42.8 & 45.7 & 44.6 & 42.9 & 44.4 & 46.4 & 42.9 & 43.0 \\
\hline Forex time deposits/total deposits & 39.3 & 38.7 & 43.7 & 46.1 & 43.6 & 43.3 & 46.5 & 44.0 & 41.4 & 46.8 & 46.4 \\
\hline Currency/broad money & 32.9 & 25.7 & 18.7 & 17.0 & 14.9 & 17.5 & 15.7 & 13.1 & 12.0 & 13.5 & 12.4 \\
\hline Demand deposits/broad money & 14.2 & 14.2 & 11.6 & 9.2 & 9.0 & 10.0 & 8.9 & 10.0 & 10.7 & 8.9 & 9.3 \\
\hline Time deposits/broad money & 52.9 & 60.1 & 69.7 & 73.9 & 76.1 & 72.5 & 75.4 & 76.8 & 77.2 & 77.5 & 78.3 \\
\hline Ratio (percent): Forex deposits/BM & 26.4 & 28.8 & 35.6 & 38.3 & 37.2 & 35.7 & 39.2 & 38.3 & 36.4 & 40.4 & 40.7 \\
\hline
\end{tabular}

Sources: Data provided by the Bank of Mongolia; and Fund staff estimates. 
Table 30. Mongolia: Balance Sheet of the Bank of Mongolia, 2001-06

\begin{tabular}{|c|c|c|c|c|c|c|c|c|c|c|c|}
\hline & \multirow{2}{*}{$\frac{2001}{\mathrm{Dec} .}$} & \multirow{2}{*}{$\frac{2002}{\text { Dec. }}$} & \multirow{2}{*}{$\frac{2003}{\text { Dec. }}$} & \multirow{2}{*}{$\frac{2004}{\text { Dec. }}$} & \multicolumn{4}{|c|}{2005} & \multicolumn{3}{|c|}{2006} \\
\hline & & & & & Mar. & Jun. & Sep. & Dec. & Mar. & Jun. & Sep. \\
\hline & \multicolumn{11}{|c|}{ (In billions of togrogs) } \\
\hline Reserve money & 144 & 175 & 201 & 235 & 253 & 296 & 297 & 281 & 308 & 376 & 377 \\
\hline Currency outside Banks & 109 & 121 & 131 & 144 & 133 & 177 & 174 & 152 & 145 & 198 & 189 \\
\hline DMB reserves & 35 & 55 & 69 & 91 & 120 & 119 & 123 & 129 & 163 & 178 & 187 \\
\hline Cash in vaults & 10 & 14 & 21 & 25 & 27 & 27 & 32 & 39 & 42 & 43 & 50 \\
\hline Demand deposits of DMBs & 25 & 41 & 48 & 66 & 93 & 92 & 90 & 90 & 121 & 135 & 137 \\
\hline Deposits of business units & 0 & 0 & 0 & 0 & 0 & 0 & 0 & 0 & 0 & 0 & 0 \\
\hline Net Foreign Assets & 177 & 254 & 151 & 199 & 224 & 253 & 315 & 372 & 415 & 469 & 609 \\
\hline Net international reserves & 176 & 254 & 151 & 198 & 222 & 252 & 310 & 364 & 411 & 449 & 595 \\
\hline Assets & 228 & 302 & 238 & 251 & 272 & 300 & 354 & 407 & 449 & 489 & 633 \\
\hline Minus: Liabilities & 52 & 48 & 87 & 54 & 49 & 47 & 44 & 43 & 39 & 39 & 38 \\
\hline Other assets, net & 0 & 0 & 0 & 1 & 1 & 1 & 5 & 8 & 4 & 20 & 14 \\
\hline Assets & 0 & 0 & 0 & 1 & 1 & 1 & 5 & 8 & 4 & 20 & 14 \\
\hline Minus: Liabilities & 0 & 0 & 0 & 0 & 0 & 0 & 0 & 0 & 0 & 0 & 0 \\
\hline Net Domestic Assets & -32 & -79 & 50 & 36 & 30 & 42 & -18 & -91 & -107 & -93 & -233 \\
\hline Net Credit to Government & 35 & 6 & 128 & 106 & 84 & 87 & 45 & 52 & -2 & -72 & -190 \\
\hline Credit & 52 & 40 & 219 & 159 & 153 & 151 & 150 & 143 & 130 & 129 & 107 \\
\hline Government bonds & 52 & 40 & 59 & 53 & 49 & 47 & 44 & 43 & 39 & 39 & 82 \\
\hline Treasury IMF account & 38 & 40 & 55 & 53 & 49 & 47 & 44 & 43 & 38 & 38 & 36 \\
\hline Reconstruction bonds & 14 & 0 & 4 & 0 & 0 & 0 & 0 & 0 & 1 & 0 & 0 \\
\hline Treasury bills & 0 & 0 & 0 & 0 & 0 & 0 & 0 & 0 & 0 & 0 & 45 \\
\hline Other & 0 & 0 & 160 & 105 & 104 & 104 & 106 & 99 & 91 & 91 & 26 \\
\hline Minus: Deposits & 17 & 34 & 92 & 53 & 69 & 63 & 105 & 90 & 132 & 201 & 297 \\
\hline Domestic currency & 13 & 30 & 73 & 43 & 28 & 36 & 55 & 48 & 88 & 97 & 112 \\
\hline Foreign currency & 4 & 4 & 19 & 10 & 40 & 27 & 50 & 42 & 45 & 104 & 185 \\
\hline Claims on deposit money banks & 7 & 8 & 13 & 22 & 22 & 19 & 18 & 18 & 18 & 18 & 18 \\
\hline Claims on nonbanks & 1 & 1 & 1 & 0 & 0 & 0 & 0 & 0 & 0 & 0 & 0 \\
\hline Minus: Central bank bills (net) & 50 & 61 & 76 & 69 & 70 & 82 & 84 & 126 & 110 & 69 & 84 \\
\hline Other items, net & -26 & -33 & -15 & -23 & -7 & 18 & 3 & -35 & -13 & 30 & 23 \\
\hline Of which: precious metals & 13 & 7 & 8 & 6 & 12 & 34 & 0 & 0 & 0 & 0 & 0 \\
\hline \multicolumn{12}{|l|}{ Memoranda items: } \\
\hline Reserve money growth (12 month percent change) & 8.4 & 21.7 & 14.7 & 16.8 & 10.5 & 20.4 & 16.3 & 19.7 & 21.7 & 27.2 & 26.8 \\
\hline Broad money/reserve money (ratio) & 2.30 & 2.68 & 3.50 & 3.60 & 3.53 & 3.41 & 3.74 & 4.13 & 3.92 & 3.89 & 4.06 \\
\hline
\end{tabular}

Sources: Data provided by the Bank of Mongolia; and Fund staff estimates. 
Table 31. Mongolia: Consolidated Balance Sheet of Commercial Banks, 2001-06

\begin{tabular}{|c|c|c|c|c|c|c|c|c|c|c|c|}
\hline & \multirow{2}{*}{$\frac{2001}{\text { Dec. }}$} & \multirow{2}{*}{$\frac{2002}{\text { Dec. }}$} & \multirow{2}{*}{$\frac{2003}{\mathrm{Dec} .}$} & \multirow{2}{*}{$\frac{2004}{\text { Dec. }}$} & \multicolumn{4}{|c|}{2005} & \multicolumn{3}{|c|}{2006} \\
\hline & & & & & Mar. & Jun. & Sep. & Dec. & Mar. & Jun. & Sep. \\
\hline & \multicolumn{11}{|c|}{ (In billions of togrogs) } \\
\hline Assets & 226 & 354 & 585 & 727 & 781 & 852 & 956 & 1,028 & 1,079 & 1,284 & 1,357 \\
\hline Net foreign assets & 44 & 54 & 81 & 84 & 107 & 123 & 166 & 172 & 140 & 322 & 336 \\
\hline Net international reserves & 51 & 68 & 128 & 96 & 120 & 136 & 178 & 187 & 153 & 333 & 347 \\
\hline Assets & 52 & 71 & 132 & 138 & 160 & 170 & 217 & 227 & 194 & 379 & 402 \\
\hline Minus: Liabilities & 2 & 3 & 5 & 41 & 40 & 34 & 39 & 40 & 41 & 47 & 54 \\
\hline Other foreign assets, net & -7 & -13 & -47 & -13 & -13 & -13 & -12 & -15 & -13 & -10 & -11 \\
\hline Assets & 0 & 0 & 0 & 0 & 0 & 0 & 0 & 0 & 0 & 0 & 0 \\
\hline Minus: Liabilities & 7 & 13 & 47 & 13 & 13 & 13 & 12 & 15 & 13 & 10 & 11 \\
\hline Net domestic assets & 182 & 299 & 504 & 643 & 675 & 729 & 790 & 855 & 939 & 962 & 1,022 \\
\hline Reserves & 35 & 55 & 69 & 88 & 116 & 116 & 118 & 126 & 155 & 159 & 169 \\
\hline Cash & 10 & 14 & 21 & 25 & 27 & 27 & 32 & 39 & 42 & 43 & 50 \\
\hline Deposits with BOM & 25 & 41 & 48 & 64 & 89 & 89 & 86 & 87 & 114 & 116 & 119 \\
\hline Central bank bills & 50 & 61 & 76 & 69 & 70 & 81 & 83 & 126 & 109 & 69 & 84 \\
\hline Domestic credit & 134 & 236 & 473 & 634 & 663 & 717 & 783 & 852 & 949 & 1,054 & 1,099 \\
\hline Net credit to government & -3 & 1 & 24 & -12 & -19 & -39 & -38 & -53 & -47 & -49 & -77 \\
\hline Claims on Government & 32 & 31 & 47 & 31 & 27 & 12 & 9 & 3 & 5 & 5 & 7 \\
\hline Less: Government deposits & 36 & 30 & 23 & 43 & 46 & 51 & 46 & 56 & 52 & 54 & 84 \\
\hline Loans to nonbanks & 138 & 235 & 449 & 646 & 682 & 756 & 821 & 905 & 996 & 1,103 & 1,177 \\
\hline Public enterprises & 10 & 11 & 16 & 13 & 14 & 22 & 21 & 34 & 29 & 30 & 33 \\
\hline Private sector & 115 & 204 & 390 & 552 & 581 & 646 & 701 & 776 & 858 & 966 & 1,011 \\
\hline Nonperforming loans & 11 & 17 & 37 & 71 & 76 & 76 & 82 & 79 & 90 & 89 & 110 \\
\hline Accrued interest receivable on loan & 2 & 4 & 7 & 11 & 11 & 12 & 17 & 16 & 19 & 19 & 23 \\
\hline Other assets, net & -36 & -52 & -114 & -149 & -174 & -185 & -194 & -248 & -275 & -321 & -331 \\
\hline Liabilities & 226 & 354 & 585 & 727 & 781 & 852 & 956 & 1,028 & 1,079 & 1,284 & 1,357 \\
\hline Deposits & 222 & 349 & 572 & 703 & 760 & 832 & 937 & 1,009 & 1,061 & 1,265 & 1,339 \\
\hline Demand deposits & 47 & 67 & 81 & 78 & 81 & 101 & 99 & 117 & 130 & 130 & 142 \\
\hline Time and savings deposits & 88 & 147 & 240 & 301 & 347 & 371 & 403 & 448 & 492 & 543 & 576 \\
\hline Foreign currency deposits & 87 & 135 & 250 & 324 & 332 & 360 & 436 & 445 & 439 & 592 & 621 \\
\hline Deposits of NBFls & 0 & 0 & 0 & 1 & 0 & 0 & 0 & 0 & 0 & 5 & 3 \\
\hline Borrowing from BoM & 4 & 4 & 13 & 24 & 22 & 19 & 18 & 18 & 18 & 19 & 19 \\
\hline & \multicolumn{11}{|c|}{ (In millions of U.S. dollars) } \\
\hline \multicolumn{12}{|l|}{ Memoranda items: } \\
\hline Net foreign assets & 39.5 & 48.2 & 69.2 & 69.4 & 89.6 & 103.0 & 136.3 & 141.0 & 119.4 & 274.9 & 287.6 \\
\hline Foreign currency deposits & 79.2 & 120.2 & 214.2 & 268.2 & 278.2 & 302.1 & 358.6 & 364.1 & 374.2 & 504.9 & 531.9 \\
\hline
\end{tabular}

Sources: Data provided by the Bank of Mongolia; and Fund staff estimates. 
Table 32. Mongolia: Distribution of Bank Credit to the Nongovernment Sector, 2001-06

(In percent of total loans; end of period)

\begin{tabular}{|c|c|c|c|c|c|c|c|}
\hline & \multirow{2}{*}{$\frac{2001}{\text { Dec. }}$} & \multirow{2}{*}{$\frac{2002}{\text { Dec. }}$} & \multirow{2}{*}{$\frac{2003}{\text { Dec. }}$} & \multirow{2}{*}{$\frac{2004}{\text { Dec. }}$} & \multirow{2}{*}{$\frac{2005}{\text { Dec. }}$} & \multicolumn{2}{|c|}{2006} \\
\hline & & & & & & Mar. & Jun. \\
\hline By maturity $1 /$ & 100.0 & 100.0 & 100.0 & 100.0 & 100.0 & 100.0 & 100.0 \\
\hline Short-term & 91.4 & 91.0 & 76.2 & 78.5 & 73.0 & 72.1 & 63.8 \\
\hline Medium-term & 5.1 & 5.8 & 20.9 & 16.8 & 22.9 & 23.4 & 31.7 \\
\hline Long-term & 3.5 & 3.2 & 2.9 & 4.7 & 4.2 & 4.5 & 4.5 \\
\hline By economic sectors & 100.0 & 100.0 & 100.0 & 100.0 & 100.0 & 100.0 & 100.0 \\
\hline Industrial & 57.6 & 50.0 & 41.8 & 41.3 & 41.7 & 40.8 & 38.3 \\
\hline Agriculture, hunting and forestry & 5.4 & 4.1 & 5.1 & 4.6 & 6.2 & 6.9 & 6.9 \\
\hline Mining and quarrying & 15.5 & 16.0 & 8.3 & 8.3 & 9.3 & 9.4 & 7.6 \\
\hline Manufacturing & 27.7 & 22.1 & 18.5 & 17.6 & 14.9 & 14.3 & 13.8 \\
\hline Electricity, gas and water supply & 3.3 & 1.6 & 2.1 & 2.6 & 2.4 & 2.0 & 1.6 \\
\hline Construction & 5.7 & 6.3 & 7.8 & 8.2 & 9.0 & 8.2 & 8.4 \\
\hline Non-industrial & 42.4 & 50.0 & 58.2 & 58.7 & 58.3 & 59.2 & 61.7 \\
\hline Real estate & 0.8 & 1.1 & 2.3 & 2.8 & 2.6 & 2.8 & 2.5 \\
\hline Transport and communications & 1.7 & 3.1 & 3.1 & 2.8 & 4.5 & 5.2 & 5.4 \\
\hline Education and health & 1.0 & 0.6 & 0.5 & 1.1 & 0.8 & 0.9 & 1.0 \\
\hline Financial intermediary & 0.4 & 0.5 & 1.1 & 0.9 & 1.1 & 0.9 & 1.1 \\
\hline Wholesale and retail trade & 28.6 & 31.7 & 35.1 & 35.7 & 33.2 & 32.1 & 33.8 \\
\hline Others & 9.9 & 13.0 & 16.3 & 15.5 & 16.1 & 17.3 & 18.0 \\
\hline By institutional sector & 100.0 & 100.0 & 100.0 & 100.0 & 100.0 & 100.0 & 100.0 \\
\hline Public enterprises 2/ & 7.7 & 5.3 & 3.9 & 2.3 & 4.3 & 3.3 & 3.1 \\
\hline Private sector $2 /$ & 68.5 & 62.7 & 52.8 & 58.7 & 55.5 & 55.9 & 55.1 \\
\hline Individuals & 19.0 & 27.9 & 30.1 & 35.9 & 38.6 & 39.6 & 40.5 \\
\hline Others & 4.8 & 4.2 & 13.3 & 3.1 & 1.6 & 1.1 & 1.3 \\
\hline By currency & 100.0 & 100.0 & 100.0 & 100.0 & 100.0 & 100.0 & 100.0 \\
\hline In togrogs & 62.1 & 62.5 & 57.7 & 56.1 & 55.9 & 56.3 & 55.0 \\
\hline In foreign currency & 37.9 & 37.5 & 42.3 & 43.9 & 44.1 & 43.7 & 45.0 \\
\hline \multicolumn{8}{|l|}{ Memorandum item: } \\
\hline Total credit (In billions of togrog) 3/ & 124.2 & 214.9 & 409.9 & 547.7 & 789.2 & 872.0 & 966.2 \\
\hline
\end{tabular}

Source: Data provided by the Bank of Mongolia.

1/ Short-term: up to and including one year; medium-term: more than one and up to and including four years; long-term: over four years.

2/ Including cooperatives.

3/ Including foreign currency-denominated credits. 
Table 33. Mongolia: Net Credit to Government, 2001-06

\begin{tabular}{|c|c|c|c|c|c|c|c|c|c|c|c|}
\hline & \multirow{2}{*}{$\frac{2001}{\text { Dec. }}$} & \multirow{2}{*}{$\frac{2002}{\text { Dec. }}$} & \multirow{2}{*}{$\frac{2003}{\text { Dec. }}$} & \multirow{2}{*}{$\frac{2004}{\text { Dec. }}$} & \multicolumn{4}{|c|}{2005} & \multicolumn{3}{|c|}{2006} \\
\hline & & & & & Mar. & Jun. & Sep. & $\overline{\text { Dec. }}$ & Mar. & Jun. & Sep. \\
\hline & \multicolumn{11}{|c|}{ (In billions of togrogs) } \\
\hline Net claims on government & 31.5 & 7.4 & 151.9 & 94.0 & 65.1 & 48.2 & 7.0 & -0.6 & -49.9 & -120.9 & -267.1 \\
\hline Claims & 84.3 & 70.5 & 266.4 & 190.0 & 179.8 & 162.1 & 158.7 & 145.8 & 135.0 & 134.1 & 114.0 \\
\hline Minus: Deposits & 52.9 & 63.2 & 114.4 & 96.0 & 114.7 & 113.9 & 151.7 & 146.4 & 184.8 & 254.9 & 381.0 \\
\hline Bank of Mongolia (net) & 35.0 & 6.3 & 127.8 & 105.8 & 84.4 & 87.5 & 44.9 & 52.3 & -2.5 & -71.6 & -189.9 \\
\hline Claims on Government & 51.9 & 39.8 & 219.5 & 158.8 & 153.0 & 150.6 & 150.1 & 142.6 & 129.9 & 129.1 & 107.4 \\
\hline Loans to the MoF & 0.0 & 0.0 & 0.0 & 0.0 & 103.6 & 103.7 & 105.6 & 94.4 & 90.7 & 90.6 & 22.4 \\
\hline FX financing without tugrik funds & 0.0 & 0.0 & 160.2 & 105.3 & 0.0 & 0.0 & 0.0 & 5.0 & 0.0 & 0.0 & 3.2 \\
\hline Government bonds & 13.6 & 0.0 & 4.4 & 0.1 & 0.2 & 0.1 & 0.2 & 0.4 & 0.7 & 0.3 & 45.4 \\
\hline Reconstruction bonds & 13.6 & 0.0 & 4.4 & 0.1 & 0.2 & 0.1 & 0.2 & 0.4 & 0.7 & 0.3 & 0.5 \\
\hline Treasury IMF account & 38.3 & 39.8 & 54.8 & 53.4 & 49.2 & 46.8 & 44.2 & 42.9 & 38.5 & 38.2 & 36.4 \\
\hline Less: Deposits & 16.9 & 33.5 & 91.7 & 53.0 & 68.6 & 63.1 & 105.2 & 90.3 & 132.4 & 200.7 & 297.3 \\
\hline Budget deposits & 7.7 & 19.0 & 91.7 & 52.3 & 68.4 & 62.2 & 104.4 & 90.3 & 132.2 & 200.4 & 297.3 \\
\hline In domestic currency & 3.9 & 15.2 & 73.0 & 42.0 & 28.0 & 34.8 & 54.1 & 48.1 & 87.7 & 96.4 & 111.9 \\
\hline In foreign currency & 3.9 & 3.7 & 18.7 & 10.2 & 40.5 & 27.4 & 50.2 & 42.2 & 44.5 & 104.0 & 185.4 \\
\hline Budget reserves & 3.5 & 0.0 & 0.0 & 0.8 & 0.1 & 0.9 & 0.8 & 0.0 & 0.2 & 0.3 & 0.0 \\
\hline Commercial banks (net) & -3.5 & 1.1 & 24.2 & -11.8 & -19.3 & -39.3 & -37.8 & -52.9 & -47.4 & -49.3 & -77.1 \\
\hline Claims on Government & 32.5 & 30.7 & 46.9 & 31.2 & 26.8 & 11.5 & 8.6 & 3.2 & 5.0 & 4.9 & 6.6 \\
\hline Advance financing of $\mathrm{MoF}$ & 1.8 & 0.1 & 0.0 & 0.2 & 0.8 & 1.6 & 2.1 & 0.6 & 0.8 & 0.8 & 2.4 \\
\hline Government securities & 30.6 & 30.6 & 46.8 & 31.0 & 25.7 & 9.8 & 6.4 & 2.4 & 4.0 & 4.0 & 4.0 \\
\hline Inherited and directed credits & 0.0 & 0.0 & 0.0 & 0.0 & 0.0 & 0.0 & 0.0 & 0.0 & 0.0 & 0.0 & 0.0 \\
\hline Accrued interest receivable & 0.0 & 0.1 & 0.1 & 0.0 & 0.3 & 0.2 & 0.1 & 0.2 & 0.2 & 0.2 & 0.2 \\
\hline Less: Government deposits & 35.9 & 29.7 & 22.7 & 43.0 & 46.1 & 50.8 & 46.5 & 56.1 & 52.4 & 54.2 & 83.8 \\
\hline
\end{tabular}

Sources: Data provided by the Bank of Mongolia; and Fund staff estimates. 


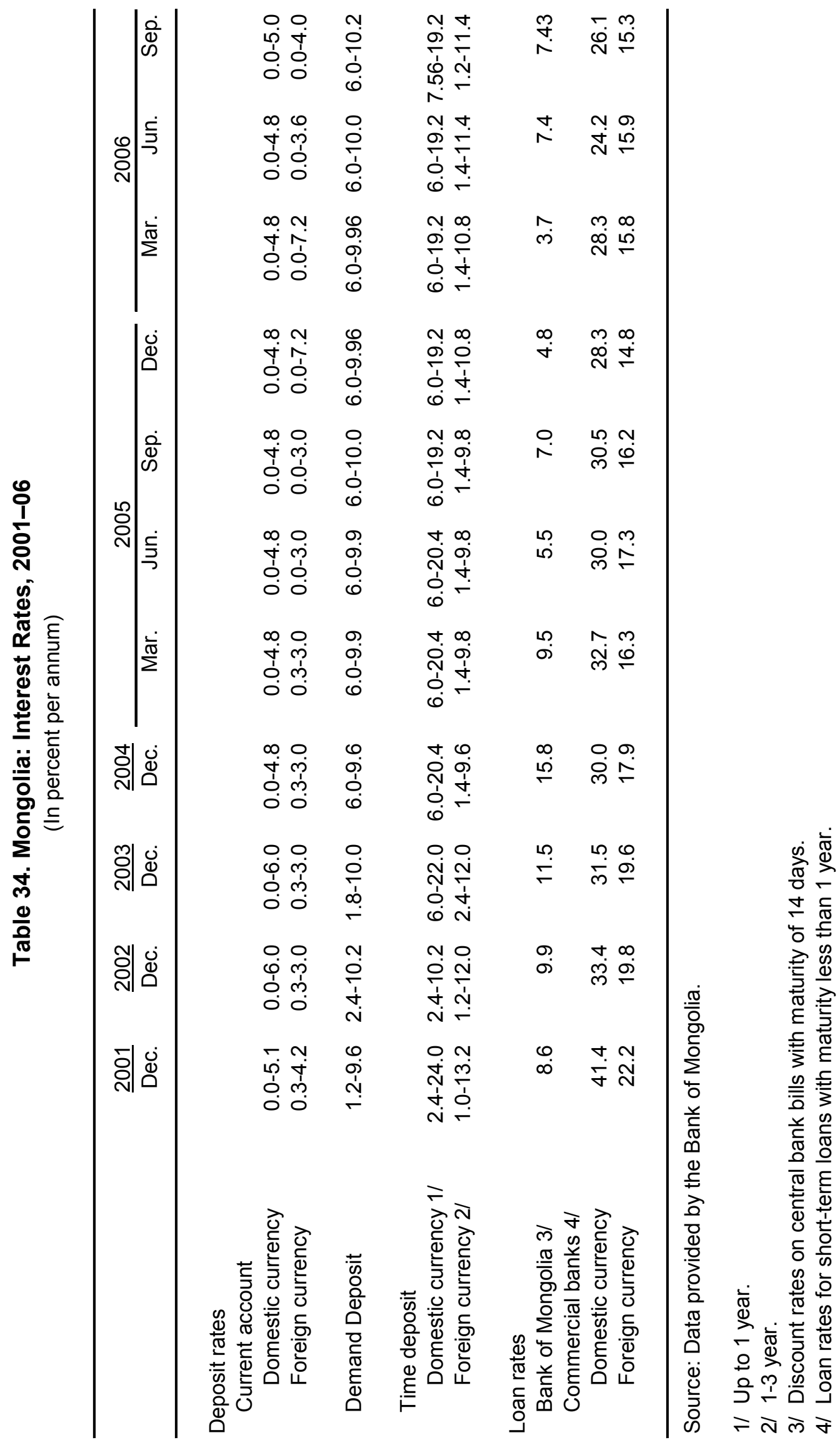


Table 35. Mongolia: Financial Soundness Indicators for Banking Sector, 2001-06

(In percent; unless otherwise indicated)

\begin{tabular}{|c|c|c|c|c|c|c|}
\hline & 2001 & 2002 & 2003 & 2004 & 2005 & $\frac{2006}{\text { June }}$ \\
\hline \multicolumn{7}{|l|}{ Capital Adequacy } \\
\hline Tier I capital ratio & 21.6 & 17.7 & 18.5 & 17.4 & 15.8 & 15.3 \\
\hline Total regulatory capital/risk-weighted assets & 24.6 & 20.0 & 20.4 & 20.0 & 18.2 & 17.2 \\
\hline Total regulatory capital/total assets & 14.2 & 12.4 & 13.4 & 15.6 & 13.6 & 12.9 \\
\hline \multicolumn{7}{|l|}{$\begin{array}{l}\text { Asset Quality } \\
\text { Distribution of risk weiaht categorv in (billion toaroa) }\end{array}$} \\
\hline 0 percent & 0.0 & 0.0 & 0.0 & 0.0 & 0.0 & 0.0 \\
\hline 20 percent & 9.7 & 13.5 & 26.8 & 31.1 & 52.0 & 70.9 \\
\hline 50 percent & 0.2 & 2.1 & 2.6 & 13.0 & 22.2 & 35.0 \\
\hline 100 percent & 174.4 & 283.5 & 499.2 & 739.8 & 994.7 & $1,218.3$ \\
\hline Large exposures/total assets & $\mathrm{n} / \mathrm{a}$ & 19.2 & 22.4 & 23.3 & 22.5 & 20.5 \\
\hline Large exposure/total capital & $\mathrm{n} / \mathrm{a}$ & 154.6 & 167.7 & 149.8 & 165.8 & 159.2 \\
\hline \multicolumn{7}{|l|}{ Connected lending/total capital } \\
\hline \multicolumn{7}{|l|}{ Directed lending/total capital } \\
\hline Foreign exchange loans/total loans & 35.2 & 32.5 & 42.8 & 45.6 & 47.0 & 47.9 \\
\hline NPLs/total gross loans (or exposures) & 6.7 & 5.0 & 4.7 & 6.0 & 5.6 & 5.5 \\
\hline NPLs net of provisions/total capital & -0.5 & -1.0 & 0.0 & 0.7 & 0.2 & 2.1 \\
\hline Provisions to NPLs & 102.8 & 105.2 & 99.9 & 97.2 & 99.2 & 91.8 \\
\hline \multicolumn{7}{|l|}{ Asset Sectoral Concentration } \\
\hline Agriculture, hunting, forestry and fishing & 4.8 & 4.1 & 5.7 & 4.7 & 6.7 & $\ldots$ \\
\hline Electricity, steam and water supply & 2.8 & 1.5 & 1.9 & 2.5 & 2.2 & $\ldots$ \\
\hline Construction & 4.3 & 6.2 & 7.5 & 8.6 & 8.9 & $\ldots$ \\
\hline Mining and quarrying & 17.5 & 15.4 & 8.4 & 8.6 & 9.0 & $\ldots$ \\
\hline Manufacturing & 26.5 & 24.2 & 20.1 & 18.7 & 16.2 & $\ldots$ \\
\hline Wholesale \& retail trade, repair of goods & 27.4 & 30.8 & 34.0 & 34.6 & 33.2 & $\ldots$ \\
\hline Tourism and hotels, restaurants & 3.5 & 1.7 & 1.8 & 2.0 & 2.1 & $\ldots$ \\
\hline Transport, storage and communication & 2.3 & 2.9 & 3.0 & 2.8 & 4.3 & $\ldots$ \\
\hline Immovable asset renting business & 0.6 & 1.1 & 2.2 & 2.6 & 2.4 & $\ldots$ \\
\hline Health and education & 0.8 & 0.6 & 0.5 & 1.0 & 0.7 & $\ldots$ \\
\hline Financial intermediaries & 0.6 & 0.5 & 1.0 & 0.9 & 1.0 & $\ldots$ \\
\hline Others & 8.8 & 11.0 & 13.8 & 13.1 & 13.2 & $\ldots$ \\
\hline \multicolumn{7}{|l|}{ Profitability } \\
\hline Return on (average) assets & 5.9 & 4.3 & 3.1 & 2.5 & 2.2 & 2.0 \\
\hline Return on (average) equity & 23.2 & 20.8 & 14.7 & 12.3 & 12.1 & 13.6 \\
\hline Interest margin/gross income & 41.3 & 39.8 & 35.9 & 31.5 & 30.9 & 27.7 \\
\hline Expenses/income & 69.2 & 78.9 & 84.7 & 85.5 & 86.0 & 86.6 \\
\hline Non-interest expenses/gross income & 55.4 & 50.3 & 49.1 & 58.8 & 54.3 & 59.7 \\
\hline Personnel expenses to noninterest expenses & 26.0 & 22.4 & 22.3 & 26.7 & 28.5 & 27.2 \\
\hline Trading and fee income to total income & 19.8 & 23.1 & 10.8 & 13.7 & 16.2 & 16.0 \\
\hline \multicolumn{7}{|l|}{ Liquidity } \\
\hline Loans to deposits & 92.8 & 100.0 & 113.1 & 116.6 & 121.8 & 111.9 \\
\hline Liquid assets/total assets & 41.3 & 39.9 & 35.3 & 31.6 & 36.0 & 36.2 \\
\hline Liquid assets/short-term liabilities & 80.6 & 90.9 & 83.5 & 28.8 & 37.7 & 35.7 \\
\hline Demand deposits/total liabilities & 11.4 & 12.0 & 10.9 & 11.9 & 14.0 & 13.9 \\
\hline Deposits to total non-interbank loans & 89.9 & 83.8 & 85.4 & 82.5 & 72.6 & 69.6 \\
\hline \multicolumn{7}{|l|}{ Memorandum item: } \\
\hline Net forex open position to total capital & 12.4 & 8.9 & 36.5 & 33.6 & 27.4 & 30.6 \\
\hline
\end{tabular}

Source: Data provided by the Bank of Mongolia. 
Table 36. Mongolia: Balance of Payments, 2001-06

(In millions of U.S. dollars; unless indicated otherwise)

\begin{tabular}{|c|c|c|c|c|c|c|}
\hline & 2001 & 2002 & 2003 & 2004 & 2005 & $\frac{2006}{\text { Est. }}$ \\
\hline Trade balance & -169.9 & -228.9 & -199.3 & -149.0 & -155.1 & 15.6 \\
\hline Exports, f.o.b. & 523.2 & 523.9 & 627.3 & 872.1 & $1,068.6$ & $1,547.7$ \\
\hline Mineral & 247.5 & 285.0 & 351.0 & 555.6 & 755.6 & $\ldots$ \\
\hline Of which : Copper & 147.9 & 140.2 & 163.7 & 284.3 & 326.2 & $\ldots$ \\
\hline Of which: Gold & 74.7 & 117.6 & 157.3 & 239.9 & 331.4 & \\
\hline Nonmineral & 275.7 & 239.0 & 249.1 & 297.7 & 309.3 & $\ldots$ \\
\hline Imports, c.i.f. & -693.1 & -752.8 & -826.6 & $-1,021.1$ & $-1,223.6$ & $-1,532.1$ \\
\hline Of which: Petroleum products & -124.0 & -110.0 & -142.5 & -210.2 & -302.1 & $\ldots$ \\
\hline Services, net & -22.2 & -11.8 & -49.3 & -45.6 & 64.8 & 66.3 \\
\hline Receipts & 113.5 & 184.6 & 207.9 & 337.9 & 414.4 & 446.6 \\
\hline Payments & -135.7 & -196.4 & -257.2 & -383.5 & -349.6 & -380.3 \\
\hline Income, net & 2.8 & -4.5 & -11.5 & -47.5 & -105.5 & -191.5 \\
\hline Official medium and long-term interest payments & -9.0 & -10.8 & -11.9 & -14.6 & -15.3 & -15.8 \\
\hline Private transfers (net) & 25.0 & 64.4 & 74.3 & 146.3 & 133.8 & 139.8 \\
\hline Official transfers & 72.1 & 53.0 & 49.4 & 86.9 & 88.0 & 90.2 \\
\hline Other transfers & 15.3 & 20.2 & 37.8 & 35.5 & 3.4 & 25.0 \\
\hline Current account balance ( including official transfers) & -77.0 & -107.6 & -98.6 & 26.6 & 29.4 & 145.4 \\
\hline Financial and capital account & 78.9 & 145.4 & -29.6 & 10.1 & 87.9 & 152.8 \\
\hline Direct investment & 43.0 & 77.8 & 131.5 & 128.9 & 257.6 & 329.4 \\
\hline Portfolio investment & 0.0 & 0.0 & 50.0 & -52.5 & 0.0 & 0.0 \\
\hline Medium- and long-term (net) & 68.7 & 99.0 & -170.1 & 75.5 & 60.8 & 89.8 \\
\hline Disbursements & 167.1 & 182.0 & 175.6 & 157.2 & 91.4 & 130.0 \\
\hline Amortization & -98.4 & -83.0 & -345.7 & -81.7 & -30.5 & -40.2 \\
\hline Currency and deposits, net & 3.6 & -8.7 & -21.0 & -119.5 & -162.5 & -266.4 \\
\hline Other private, net (including short-term capital flows) & -36.3 & -22.7 & -20.0 & -22.3 & -68.0 & 0.0 \\
\hline Errors and omissions & 12.7 & 28.5 & 30.6 & -4.6 & 9.0 & 0.0 \\
\hline Overall balance & 14.7 & 66.4 & -97.6 & 32.1 & 126.4 & 298.2 \\
\hline Financing & -14.7 & -66.4 & 97.6 & -32.1 & -126.4 & -298.2 \\
\hline Increase in net official reserves (-) & -19.5 & -65.6 & 96.8 & -37.4 & -131.3 & -298.2 \\
\hline Use of IMF credit (+) & -1.7 & -4.3 & 3.0 & -7.3 & -5.9 & -5.8 \\
\hline Increase in gross official reserves (-) & -17.8 & -61.4 & 93.8 & -30.1 & -125.4 & -292.4 \\
\hline Arrears accumulation $(+) /$ payments $(-)$ (net) & 4.8 & -0.7 & 0.8 & 5.4 & 4.9 & 0.0 \\
\hline Exceptional financing / rescheduling & 0.0 & 0.0 & 0.0 & 0.0 & 0.0 & 0.0 \\
\hline \multicolumn{7}{|l|}{ Memoranda items: } \\
\hline Current account balance (including official transfers; in percent of GDP) & -7.6 & -9.6 & -7.7 & 1.6 & 1.4 & 5.2 \\
\hline Net official reserves (end-period) & 160.1 & 225.8 & 128.9 & 163.6 & 298.0 & 596.2 \\
\hline Gross official reserves (end-period) & 206.8 & 271.5 & 177.7 & 207.8 & 333.2 & 625.6 \\
\hline (In months of next year's imports of goods and services) & 2.6 & 3.0 & 1.5 & 1.6 & 2.1 & 3.4 \\
\hline Debt service (in percent of exports of goods and services) & 5.3 & 4.5 & 34.0 & 7.5 & 2.9 & 2.1 \\
\hline Outstanding arrears (end-period) $1 /$ & 4.8 & 4.1 & 5.4 & 10.8 & 0.0 & 0.0 \\
\hline
\end{tabular}

Sources: Data provided by the Bank of Mongolia; and Fund staff estimates.

1/ Arrears on post-1991 Russian debt. Excluding disputed amounts with Finland. 
Table 37. Mongolia: Commodity Composition of Exports, 2001-05 (In millions of U.S. dollars, unless otherwise indicated; unit values are denominated in U.S. dollars)

\begin{tabular}{|c|c|c|c|c|c|}
\hline & 2001 & 2002 & 2003 & 2004 & 2005 \\
\hline Copper concentrate (value) & 147.9 & 140.2 & 163.7 & 284.3 & 326.2 \\
\hline Volume (concentrate in '000 tons) & 540.9 & 548.6 & 568.9 & 562.6 & 587.1 \\
\hline Refined copper equivalent & 146.0 & 153.6 & 159.3 & 157.5 & 164.4 \\
\hline Unit value--refined (per ton) & $1,012.8$ & 912.9 & $1,027.7$ & $1,804.8$ & $1,984.5$ \\
\hline Molybdenum concentrate & 5.1 & 10.1 & 15.0 & 20.0 & 46.7 \\
\hline Volume (tons) & $3,081.8$ & $3,469.0$ & $3,967.3$ & $2,250.2$ & $2,395.1$ \\
\hline Unit value (per ton) & $1,647.9$ & $2,916.5$ & $3,790.7$ & $8,888.1$ & $19,488.5$ \\
\hline Fluorite concentrate & 19.8 & 17.0 & 15.0 & 11.4 & 24.7 \\
\hline Volume ('000 tons) & 215.6 & 192.5 & 187.5 & 140.5 & 311.4 \\
\hline Unit value (per ton) & 92.0 & 88.1 & 80.0 & 81.1 & 79.3 \\
\hline Coal & & & & & 26.6 \\
\hline Volume (concentrate in '000 tons) & & & & & $2,217.6$ \\
\hline Unit value (per ton) & & & & & 12.0 \\
\hline Gold & 74.7 & 117.6 & 157.3 & 239.9 & 331.4 \\
\hline Volume (kg) & $11,045.6$ & $12,388.3$ & $14,220.6$ & $19,043.6$ & $23,811.5$ \\
\hline Unit value (per kg) & $6,761.3$ & $9,496.5$ & $11,061.1$ & $12,597.4$ & $13,918.1$ \\
\hline Sawn wood & 0.1 & 0.0 & 0.0 & 0.0 & 0.1 \\
\hline Volume ('000 cubic meters) & 1.0 & 0.0 & 0.0 & 0.2 & 0.5 \\
\hline Unit value (per cubic meter) & 148.7 & 0.0 & 0.0 & 134.0 & 137.0 \\
\hline Cashmere tops & 0.3 & 0.9 & 1.8 & 1.1 & 1.1 \\
\hline Volume (tons) & 2.8 & 15.4 & 28.1 & 12.7 & 13.9 \\
\hline Unit value (per kg) & 103.0 & 59.1 & 63.1 & 82.7 & 81.7 \\
\hline Cashmere, dehaired & 55.0 & 30.5 & 25.7 & 44.1 & 52.8 \\
\hline Volume (tons) & $1,006.6$ & 632.3 & 563.1 & 831.7 & 919.2 \\
\hline Unit value (per kg) & 54.7 & 48.3 & 45.6 & 53.0 & 57.4 \\
\hline Cashmere garments & 11.6 & 12.8 & 15.6 & 33.1 & 17.5 \\
\hline Volume ('000 pieces) & 325.2 & 483.6 & 645.5 & $1,500.1$ & 476.5 \\
\hline Unit value (per piece) & 35.7 & 26.4 & 24.1 & 22.1 & 36.8 \\
\hline Cashmere, greasy/raw & 0.9 & 0.9 & 1.1 & 0.6 & 0.3 \\
\hline Volume (tons) & 50.2 & 53.7 & 67.1 & 43.4 & 11.3 \\
\hline Unit value (per kg) & 17.3 & 16.8 & 17.0 & 13.8 & 26.8 \\
\hline Textiles & 44.2 & 18.8 & 37.4 & 96.5 & 42.3 \\
\hline Volume ('000 pieces) & $10,066.8$ & $6,371.0$ & $4,329.6$ & $26,900.6$ & $13,234.3$ \\
\hline Unit price & 4.4 & 2.9 & 8.6 & 3.6 & 3.2 \\
\hline Camel wool, raw & 2.2 & 0.7 & 0.7 & 0.7 & 1.9 \\
\hline Volume (tons) & 964.0 & 345.0 & 354.8 & 281.8 & 609.2 \\
\hline Unit value (per kg) & 2.3 & 2.1 & 1.9 & 2.4 & 3.1 \\
\hline Skin and hides & 16.2 & 11.3 & 6.1 & 5.9 & 3.0 \\
\hline Volume ('000 pieces) & $1,761.4$ & $1,332.2$ & 409.5 & 406.4 & 437.8 \\
\hline Unit price & 9.2 & 8.5 & 14.8 & 14.4 & 6.8 \\
\hline Sheepskin coats & 0.3 & 0.1 & 0.2 & 0.2 & 0.5 \\
\hline Volume ('000 pieces) & 1.4 & 1.2 & 1.0 & 0.8 & 5.2 \\
\hline Unit value (per piece) & 222.2 & 111.6 & 233.1 & 205.1 & 104.5 \\
\hline Carpets & 0.9 & 0.9 & 0.0 & 0.0 & 0.0 \\
\hline Volume ('000 square meters) & 84.8 & 101.0 & 0.0 & 0.0 & 0.0 \\
\hline Unit value (per square meter) & 10.1 & 9.4 & 0.0 & 0.0 & 0.0 \\
\hline Meat & 18.5 & 20.5 & 15.7 & 13.2 & 10.1 \\
\hline Volume ('000 tons) & 16.9 & 17.2 & 11.0 & 52.2 & 34.9 \\
\hline Unit value (per ton) & $1,092.9$ & $1,187.5$ & $1,434.2$ & 252.2 & 289.8 \\
\hline Scrap Metal & 4.0 & 3.5 & 3.7 & 8.7 & 8.3 \\
\hline Volume ('000 tons) & 10.7 & 8.6 & 8.0 & 8.7 & 3.8 \\
\hline Unit value (per ton) & 372.0 & 411.7 & 467.6 & $1,002.2$ & $2,178.7$ \\
\hline Other & 121.6 & 137.9 & 168.3 & 112.6 & 175.0 \\
\hline Total Exports & 523.2 & 523.9 & 627.3 & 872.1 & $1,068.6$ \\
\hline Mineral exports & 247.5 & 285.0 & 351.0 & 555.6 & 755.6 \\
\hline Nonmineral exports & 275.7 & 238.9 & 276.3 & 316.5 & 313.0 \\
\hline \multicolumn{6}{|l|}{ Memoranda items } \\
\hline \multicolumn{6}{|c|}{ (In percent of total exports) } \\
\hline Mineral exports & 47.3 & 54.4 & 56.0 & 63.7 & 70.7 \\
\hline \multirow[t]{2}{*}{ Nonmineral exports } & 52.7 & 45.6 & 44.0 & 36.3 & 29.3 \\
\hline & \multicolumn{5}{|c|}{ (In percent of GDP) } \\
\hline Total exports & 51.4 & 46.7 & 46.7 & 52.5 & 51.6 \\
\hline Mineral exports & 24.3 & 25.4 & 27.3 & 34.2 & 36.6 \\
\hline Nonmineral exports & 27.1 & 21.3 & 19.4 & 18.3 & 15.0 \\
\hline
\end{tabular}

Sources: Data provided by the Bank of Mongolia; and Fund staff estimates. 
Table 38. Mongolia: Commodity Composition of Imports, 2001-05

(In millions of U.S. dollars; unless otherwise indicated)

\begin{tabular}{|c|c|c|c|c|c|}
\hline & 2001 & 2002 & 2003 & 2004 & 2005 \\
\hline Food & 113.1 & 129.5 & 112.4 & 157.3 & 153.3 \\
\hline Live animals and animal products & 4.9 & 5.3 & 5.7 & 5.7 & 5.9 \\
\hline Vegetable products & 51.0 & 58.3 & 36.4 & 69.3 & 55.9 \\
\hline Animal and vegetable oil & 6.8 & 9.4 & 10.2 & 9.6 & 13.1 \\
\hline Prepared food & 50.4 & 56.6 & 60.0 & 72.7 & 78.4 \\
\hline Energy & 143.8 & 132.7 & 161.3 & 231.3 & 326.5 \\
\hline Of which: Petroleum products & 124.0 & 110.0 & 142.5 & 210.2 & 302.1 \\
\hline Equipment Goods & 180.4 & 209.9 & 250.4 & 305.4 & 372.0 \\
\hline Machinery and equipment & 112.5 & 134.4 & 165.0 & 201.5 & 256.0 \\
\hline Vehicles and transportation equipment & 67.9 & 75.5 & 85.4 & 103.9 & 116.0 \\
\hline Raw Materials and Spare Parts & 73.2 & 77.3 & 106.6 & 135.3 & 159.4 \\
\hline Chemical products & 33.0 & 34.5 & 42.1 & 46.6 & 54.5 \\
\hline Raw hides and skins & 0.7 & 0.5 & 0.4 & 0.6 & 0.7 \\
\hline Building materials & 9.8 & 10.9 & 21.0 & 17.1 & 18.7 \\
\hline Metals & 29.8 & 31.4 & 43.0 & 71.0 & 85.5 \\
\hline Consumer Goods & 119.5 & 141.3 & 156.7 & 181.7 & 171.7 \\
\hline Rubber products & 15.1 & 19.1 & 21.6 & 25.7 & 30.0 \\
\hline Wood and wood products & 2.2 & 3.2 & 4.3 & 4.3 & 5.3 \\
\hline Cellulosic materials & 10.3 & 14.9 & 25.3 & 19.1 & 29.9 \\
\hline Textile & 63.3 & 84.2 & 82.0 & 100.9 & 76.3 \\
\hline Footwear and clothes & 2.2 & 1.9 & 1.6 & 1.6 & 1.4 \\
\hline Measuring instruments & 17.5 & 9.0 & 9.7 & 16.5 & 14.5 \\
\hline Manufactured articles & 8.9 & 9.0 & 12.1 & 13.5 & 14.3 \\
\hline Other imports & 63.0 & 62.0 & 39.2 & 10.1 & 40.7 \\
\hline Total (c.i.f) & 693.1 & 752.8 & 826.6 & $1,021.1$ & $1,223.6$ \\
\hline \multicolumn{6}{|l|}{ Memoranda items: } \\
\hline Nonfood imports & 580.0 & 623.3 & 714.2 & 863.8 & $1,070.3$ \\
\hline \multirow[t]{2}{*}{ Nonenergy imports } & 549.3 & 620.1 & 665.3 & 789.8 & 897.1 \\
\hline & \multicolumn{5}{|c|}{ (In percent of GDP) } \\
\hline Total imports & 62.0 & 60.5 & 56.1 & 53.0 & 49.2 \\
\hline Food imports & 10.1 & 10.4 & 7.6 & 8.2 & 6.2 \\
\hline Petroleum product imports & 11.1 & 8.8 & 9.7 & 10.9 & 12.1 \\
\hline Nonfood imports (excluding energy) & 39.0 & 39.4 & 37.5 & 32.8 & 29.9 \\
\hline
\end{tabular}

Sources: Data provided by the Bank of Mongolia; and Fund staff estimates. 
Table 39. Mongolia: Direction of Trade, 2001-05

(In percent of total exports or imports)

\begin{tabular}{|c|c|c|c|c|c|}
\hline & 2001 & 2002 & 2003 & 2004 & 2005 \\
\hline Exports 1/ & 100.0 & 100.0 & 100.0 & 100.0 & 100.0 \\
\hline Countries of the former CMEA & 10.6 & 9.2 & 7.2 & 3.2 & 4.7 \\
\hline Former U.S.S.R. & 10.6 & 9.1 & 7.2 & 3.2 & 4.7 \\
\hline Russia & 10.3 & 8.6 & 6.3 & 2.4 & 2.6 \\
\hline Kazakhstan & 0.2 & 0.1 & 0.5 & 0.0 & 0.1 \\
\hline Other & 0.0 & 0.4 & 0.5 & 0.8 & 2.1 \\
\hline Korea, Democratic People's Republic of & 0.0 & 0.0 & 0.0 & 0.0 & 0.0 \\
\hline EU countries & 6.5 & 6.5 & 7.4 & 21.4 & 12.3 \\
\hline Belgium & 0.3 & 0.0 & 0.1 & 0.1 & 0.1 \\
\hline France & 0.0 & 0.0 & 0.3 & 1.8 & 0.1 \\
\hline Germany & 0.6 & 0.5 & 0.8 & 1.3 & 1.2 \\
\hline Italy & 3.0 & 1.7 & 1.5 & 2.0 & 2.3 \\
\hline Netherlands & 0.7 & 0.5 & 0.4 & 0.4 & 0.4 \\
\hline United Kingdom & 1.7 & 3.5 & 4.4 & 15.8 & 8.2 \\
\hline Other & 0.0 & 0.2 & 0.0 & 0.0 & 0.1 \\
\hline Other & 83.0 & 84.4 & 85.3 & 75.3 & 82.9 \\
\hline China & 53.7 & 41.7 & 46.1 & 46.8 & 48.1 \\
\hline Hong Kong, China & 1.5 & 0.6 & 0.5 & 0.8 & 0.2 \\
\hline Japan & 3.3 & 1.3 & 1.4 & 3.8 & 0.5 \\
\hline Korea & 0.9 & 4.4 & 1.2 & 1.1 & 6.1 \\
\hline Singapore & 0.0 & 0.0 & 5.8 & 2.3 & 0.1 \\
\hline Switzerland & 0.1 & 0.1 & 0.1 & 0.2 & 0.4 \\
\hline United States & 22.0 & 31.6 & 23.3 & 18.0 & 14.3 \\
\hline Other & 1.6 & 4.5 & 6.9 & 2.3 & 13.2 \\
\hline Imports & 100.0 & 100.0 & 100.0 & 100.0 & 100.0 \\
\hline Countries of the former CMEA & 40.9 & 38.5 & 37.6 & 41.0 & 43.0 \\
\hline Former U.S.S.R. & 38.7 & 36.7 & 35.2 & 38.8 & 41.2 \\
\hline Russia & 36.4 & 34.1 & 32.6 & 33.5 & 35.3 \\
\hline Kazakhstan & 0.6 & 1.1 & 0.6 & 2.6 & 3.4 \\
\hline Other & 1.7 & 1.6 & 1.9 & 2.7 & 2.5 \\
\hline Bulgaria & 0.2 & 0.1 & 0.2 & 0.2 & 0.1 \\
\hline Former Czechoslovakia 2/ & 1.0 & 0.5 & 0.7 & 0.5 & 0.4 \\
\hline Hungary & 0.2 & 0.2 & 0.5 & 0.7 & 0.3 \\
\hline Poland & 0.7 & 0.8 & 1.0 & 0.9 & 0.8 \\
\hline EU countries & 10.6 & 8.3 & 11.0 & 8.3 & 8.3 \\
\hline Denmark & 1.3 & 0.4 & 0.5 & 0.5 & 0.3 \\
\hline France & 0.9 & 0.7 & 1.4 & 1.5 & 2.5 \\
\hline Germany & 5.1 & 4.5 & 4.8 & 3.3 & 3.2 \\
\hline United Kingdom & 0.7 & 0.4 & 0.5 & 0.4 & 0.7 \\
\hline Austria & 0.1 & 0.1 & 0.7 & 0.5 & 0.1 \\
\hline Finland & 0.6 & 0.5 & 0.3 & 0.2 & 0.2 \\
\hline Other & 1.2 & 1.6 & 2.8 & 1.9 & 1.3 \\
\hline Other & 48.5 & 53.2 & 51.4 & 50.7 & 48.8 \\
\hline China & 19.3 & 20.2 & 21.8 & 22.0 & 24.9 \\
\hline Hong Kong, China & 2.5 & 4.3 & 3.0 & 3.2 & 1.0 \\
\hline India & 0.2 & 0.2 & 0.1 & 0.1 & 0.1 \\
\hline Japan & 9.5 & 6.2 & 8.0 & 7.3 & 6.4 \\
\hline Korea & 9.7 & 12.2 & 8.5 & 6.0 & 5.4 \\
\hline Singapore & 1.5 & 1.7 & 1.3 & 1.5 & 1.4 \\
\hline Switzerland & 0.8 & 0.5 & 0.6 & 0.4 & 0.1 \\
\hline United States & 2.5 & 3.5 & 2.9 & 4.6 & 3.4 \\
\hline Other & 3.2 & 4.7 & 5.3 & 5.7 & 6.1 \\
\hline
\end{tabular}

Sources: Data provided by the Bank of Mongolia; and Fund staff estimates.

1/ Data for exports of copper refer to country of initial purchaser rather than country of destination of final product.

2/ Data after 1993 refer to Czech Republic and Slovak Republic. 
Table 40. Mongolia: Services and Income Accounts, 2001-05

(In millions of U.S. dollars)

\begin{tabular}{|c|c|c|c|c|c|c|c|c|c|c|}
\hline & \multicolumn{2}{|c|}{2001} & \multicolumn{2}{|c|}{2002} & \multicolumn{2}{|c|}{2003} & \multicolumn{2}{|c|}{2004} & \multicolumn{2}{|c|}{2005} \\
\hline & Receipts & Payments & Receipts & Payments & Receipts & Payments & Receipts & Payments & Receipts & Payments \\
\hline \multicolumn{11}{|l|}{ Services } \\
\hline Passenger fares & 10.1 & 4.4 & 13.0 & 6.0 & 11.0 & 5.9 & 19.6 & 13.6 & 26.4 & 16.3 \\
\hline Railway & 3.7 & 1.1 & 6.0 & 1.9 & 4.1 & 1.5 & 14.3 & 9.9 & 20.6 & 11.0 \\
\hline Airline & 6.4 & 3.3 & 7.0 & 4.1 & 6.9 & 4.4 & 5.3 & 3.7 & 5.8 & 5.3 \\
\hline Port services & 3.1 & 23.6 & 1.9 & 18.2 & 5.4 & 35.3 & 28.7 & 31.1 & 33.0 & 33.7 \\
\hline Transit fees & 22.6 & 2.4 & 23.9 & 2.7 & 24.1 & 3.0 & 29.0 & 2.2 & 32.8 & 3.8 \\
\hline Travel & 39.3 & 55.3 & 130.1 & 119.2 & 143.0 & 107.5 & 184.7 & 147.8 & 176.8 & 125.7 \\
\hline Embassy expenses abroad & 3.9 & 5.3 & 4.8 & 5.6 & 4.8 & 5.9 & 9.2 & 5.4 & 5.3 & 8.0 \\
\hline Embassies/international organizati & 0.4 & 2.4 & 0.4 & 2.4 & 0.4 & 2.7 & 0.4 & 2.7 & 0.4 & 2.7 \\
\hline Commissions & 0.0 & 1.0 & 0.0 & 0.8 & 0.0 & 0.8 & 2.0 & 0.0 & 0.0 & 0.8 \\
\hline Communications & 7.7 & 4.4 & 6.0 & 8.6 & 4.8 & 7.4 & 4.8 & 9.1 & 14.4 & 23.4 \\
\hline Technical Assistance & 0.0 & 15.3 & 0.0 & 21.0 & 0.0 & 38.4 & 0.0 & 19.9 & 0.0 & 29.1 \\
\hline Other & 26.4 & 21.6 & 4.5 & 11.9 & 14.4 & 50.3 & 14.1 & 151.7 & 125.3 & 106.1 \\
\hline Total & 113.5 & 135.7 & 184.6 & 196.4 & 207.9 & 257.2 & 337.9 & 383.5 & 414.4 & 349.6 \\
\hline \multicolumn{11}{|l|}{ Income } \\
\hline Direct investment income & 0.0 & 3.4 & 0.0 & 5.2 & 0.0 & 6.8 & 0.0 & 45.5 & 0.0 & 96.4 \\
\hline Interest on bank deposits & 10.8 & 0.1 & 5.7 & 0.8 & 5.1 & 1.9 & 8.5 & 0.0 & 5.7 & 0.0 \\
\hline Interest on debt & 0.0 & 13.6 & 0.0 & 10.8 & 0.0 & 11.9 & 0.0 & 14.6 & 0.0 & 15.3 \\
\hline Official Medium- and long-term & 0.0 & 9.0 & 0.0 & 10.8 & 0.0 & 11.9 & 0.0 & 14.6 & 0.0 & 15.3 \\
\hline Short-term & 0.0 & 0.0 & 0.0 & 0.0 & 0.0 & 0.0 & 0.0 & 0.0 & 0.0 & 0.0 \\
\hline Private Sector & 0.0 & 4.5 & 0.0 & 2.5 & 0.0 & 3.8 & 0.0 & 1.3 & 0.0 & 3.5 \\
\hline Interest on trade credit & 0.0 & 0.4 & 0.0 & 0.5 & 0.0 & 0.9 & 0.0 & 2.6 & 0.0 & 1.5 \\
\hline Other interest & 9.9 & 0.3 & 8.4 & 1.3 & 8.8 & 3.9 & 8.1 & 0.0 & 5.0 & 0.0 \\
\hline Total & 20.7 & 17.8 & 14.1 & 18.6 & 13.9 & 25.4 & 16.5 & 64.0 & 10.7 & 116.7 \\
\hline
\end{tabular}

Sources: Data provided by the Bank of Mongolia; and Fund staff estimates. 
Table 41. Mongolia: Medium- and Long-Term Loan Disbursements, 2001-05

(In millions of U.S. dollars)

\begin{tabular}{lrrrrr}
\hline & 2001 & 2002 & 2003 & 2004 & 2005 \\
\hline Official loans & 84.2 & 83.8 & 101.2 & 128.7 & 90.4 \\
Japan & 16.3 & 14.0 & 17.7 & 25.1 & 20.9 \\
Germany & 9.9 & 8.1 & 6.9 & 5.8 & 4.7 \\
Korea & 0.5 & 16.2 & 4.6 & 0.0 & 0.0 \\
Norway & 0.0 & 0.0 & 0.0 & 3.6 & 1.8 \\
Abu Dhabi fund & 0.0 & 0.0 & 0.0 & 0.0 & 6.9 \\
Spain & 0.0 & 0.0 & 0.0 & 2.8 & 0.0 \\
Kuwait & 3.8 & 3.9 & 3.2 & 1.8 & 9.8 \\
World Bank & 23.0 & 14.4 & 27.7 & 48.9 & 13.6 \\
$\quad$ Program & 11.1 & 0.0 & 5.8 & 5.8 & 0.0 \\
Project & 11.3 & 14.2 & 21.4 & 39.2 & 13.6 \\
$\quad$ Technical assistance & 0.6 & 0.2 & 0.5 & 3.9 & 0.0 \\
Asian Development Bank & 30.0 & 26.5 & 39.5 & 39.4 & 30.0 \\
$\quad$ Balance of payments support & 10.0 & 0.0 & 20.1 & 5.0 & 8.8 \\
Project & 20.0 & 26.5 & 19.4 & 34.4 & 21.2 \\
$\quad$ Technical assistance & 0.0 & 0.0 & 0.0 & 0.0 & 0.0 \\
IFAD & 0.7 & 0.7 & 1.6 & 1.1 & 2.8 \\
Commercial loans & & & & & \\
Total & 82.9 & 98.2 & 74.4 & 28.5 & 1.0 \\
& 167.2 & 182.0 & 175.6 & 157.2 & 91.4 \\
\hline
\end{tabular}

Sources: Data provided by the Ministry of Finance; and Fund staff estimates. 
Table 42. Mongolia: Short-Term Capital Flows, 2001-05

(In millions of U.S. dollars)

\begin{tabular}{|c|c|c|c|c|c|}
\hline & 2001 & 2002 & 2003 & 2004 & 2005 \\
\hline Import credits & -11.5 & -8.5 & -20.3 & 4.8 & -4.5 \\
\hline Inflows & 5.0 & 1.8 & 2.7 & 4.8 & 11.4 \\
\hline Erdenet & 4.3 & 1.5 & 1.8 & 4.0 & 10.2 \\
\hline Others & 0.7 & 0.3 & 0.9 & 0.8 & 1.2 \\
\hline Outflows & 16.5 & 10.3 & 23.0 & $\cdots$ & 15.9 \\
\hline Erdenet & 16.5 & 10.3 & 23.0 & $\ldots$ & 15.9 \\
\hline Trade credit extended on exports & 3.3 & 6.6 & -8.7 & -0.6 & -1.5 \\
\hline Inflows & 4.5 & 7.7 & 0.0 & 0.0 & 0.0 \\
\hline Erdenet & 4.5 & 7.7 & $\ldots$ & $\ldots$ & $\ldots$ \\
\hline Outflows & 1.2 & 1.1 & 8.7 & 0.6 & 1.5 \\
\hline Others & 1.2 & 1.1 & 8.7 & 0.6 & 1.5 \\
\hline Others & -7.1 & $\ldots$ & $\ldots$ & $\ldots$ & $\ldots$ \\
\hline Inflows & 11.8 & $\ldots$ & $\ldots$ & $\ldots$ & $\ldots$ \\
\hline Erdenet & 3.7 & $\ldots$ & $\ldots$ & $\ldots$ & $\ldots$ \\
\hline Others & 8.1 & $\ldots$ & $\ldots$ & $\ldots$ & $\ldots$ \\
\hline Outflows & 18.9 & $\ldots$ & $\ldots$ & $\ldots$ & $\ldots$ \\
\hline Erdenet & 7.9 & $\ldots$ & $\ldots$ & $\ldots$ & $\ldots$ \\
\hline Others & 11.0 & $\cdots$ & $\cdots$ & $\ldots$ & $\ldots$ \\
\hline Total $1 /$ & -15.3 & -1.9 & -29.0 & 4.2 & -6.0 \\
\hline
\end{tabular}

Sources: Data provided by the Bank of Mongolia; and Fund staff estimates.

1/ As data for others are not available from 2002, total is calculated without others after 2002. 
Table 43. Mongolia: External Debt and Debt Service, 2001-05

\begin{tabular}{|c|c|c|c|c|c|}
\hline & 2001 & 2002 & 2003 & 2004 & 2005 \\
\hline & \multicolumn{5}{|c|}{ (In millions of US dollars) } \\
\hline External debt & 853.5 & 978.1 & $1,237.0$ & $1,361.3$ & $1,307.8$ \\
\hline Medium- and long-term & 806.7 & 936.1 & $1,138.1$ & $1,317.0$ & $1,271.4$ \\
\hline IMF & 46.8 & 42.0 & 48.9 & 44.3 & 36.4 \\
\hline Short-term 1/ & 0.0 & 0.0 & 50.0 & 0.0 & 0.0 \\
\hline Debt service & 33.9 & 32.0 & 284.0 & 91.1 & 42.8 \\
\hline Amortization & 24.8 & 20.9 & 272.3 & 75.2 & 27.5 \\
\hline Interest & 9.0 & 11.1 & 11.6 & 15.9 & 15.3 \\
\hline Medium- and long-term & 26.8 & 24.2 & 275.2 & 32.3 & 36.7 \\
\hline Amortization & 18.0 & 13.2 & 263.8 & 17.9 & 21.6 \\
\hline Interest & 8.8 & 11.0 & 11.4 & 14.4 & 15.1 \\
\hline IMF & 7.1 & 7.8 & 8.7 & 7.5 & 6.1 \\
\hline Repurchase/Repayments & 6.8 & 7.7 & 8.5 & 7.3 & 5.9 \\
\hline Charges & 0.2 & 0.1 & 0.2 & 0.2 & 0.2 \\
\hline \multirow[t]{2}{*}{ Short-term 1/ } & 0.0 & 0.0 & 0.0 & 51.3 & 0.0 \\
\hline & \multicolumn{5}{|c|}{ (In percent) } \\
\hline External debt/GDP & 83.8 & 87.2 & 96.2 & 83.8 & 63.3 \\
\hline Medium- and long-term & 79.2 & 83.5 & 88.5 & 81.0 & 61.6 \\
\hline IMF & 4.6 & 3.7 & 3.8 & 2.7 & 1.8 \\
\hline Short-term 1/ & 0.0 & 0.0 & 3.9 & 0.0 & 0.0 \\
\hline External debt/exports of goods and services & 134.1 & 138.1 & 148.1 & 112.5 & 88.2 \\
\hline Medium- and long-term & 126.7 & 132.1 & 136.3 & 108.8 & 85.7 \\
\hline IMF & 7.4 & 5.9 & 5.9 & 3.7 & 2.5 \\
\hline Short-term 1/ & 0.0 & 0.0 & 6.0 & 0.0 & 0.0 \\
\hline Debt-service ratio 2/ & 5.3 & 4.5 & 34.0 & 7.5 & 2.9 \\
\hline Amortization & 3.9 & 2.9 & 32.6 & 6.2 & 1.9 \\
\hline Interest & 1.4 & 1.6 & 1.4 & 1.3 & 1.0 \\
\hline Medium- and long-term & 4.2 & 3.4 & 33.0 & 2.7 & 2.5 \\
\hline Amortization & 2.8 & 1.9 & 31.6 & 1.5 & 1.5 \\
\hline Interest & 1.4 & 1.6 & 1.4 & 1.2 & 1.0 \\
\hline IMF & 1.1 & 1.1 & 1.0 & 0.6 & 0.4 \\
\hline Repurchase/repayments & 1.1 & 1.1 & 1.0 & 0.6 & 0.4 \\
\hline Charges & 0.0 & 0.0 & 0.0 & 0.0 & 0.0 \\
\hline Short-term 1/ & 0.0 & 0.0 & 0.0 & 4.2 & 0.0 \\
\hline
\end{tabular}

Sources: Data provided by the Ministry of Finance; and Fund staff estimates.

$1 /$ Includes treasury bill in US\$ to nonresident issued in relation to pre-1991 Russian debt settlement. 2/ In percent of exports of goods and services. 
Table 44. Mongolia: External Debt Stock by Creditor, 2001-05

(In millions of U.S. dollars, end of period)

\begin{tabular}{|c|c|c|c|c|c|}
\hline & 2001 & 2002 & 2003 & 2004 & 2005 \\
\hline External Debt & 853.5 & 978.1 & $1,237.0$ & $1,361.3$ & $1,307.8$ \\
\hline Medium and long-term official (excluding IMF) & 806.6 & 936.1 & $1,138.1$ & $1,317.0$ & $1,271.4$ \\
\hline Multilateral (excluding IMF) & 476.5 & 548.0 & 668.8 & 797.2 & 770.4 \\
\hline Asian Development Bank & 319.3 & 366.1 & 439.1 & 503.3 & 485.7 \\
\hline World Bank & 155.1 & 179.0 & 225.0 & 287.7 & 276.3 \\
\hline IFAD & 2.1 & 2.9 & 4.7 & 6.2 & 8.4 \\
\hline Bilateral official & 317.1 & 375.1 & 456.3 & 506.9 & 488.1 \\
\hline Paris Club & 283.5 & 322.2 & 395.7 & 444.1 & 409.3 \\
\hline Japan & 193.6 & 219.3 & 261.8 & 293.4 & 270.52 \\
\hline Russia & 26.4 & 24.5 & 22.1 & 16.7 & 16.74 \\
\hline Germany & 46.5 & 59.9 & 77.9 & 90.3 & 81.78 \\
\hline Finland & 6.0 & 5.9 & 7.9 & 8.8 & 7.60 \\
\hline Norway & 11.1 & 12.5 & 17.1 & 21.9 & 21.46 \\
\hline Spain & 0.0 & 0.0 & 8.8 & 12.9 & 11.17 \\
\hline Non-Paris Club & 33.5 & 52.9 & 60.6 & 62.8 & 78.82 \\
\hline China & 15.5 & 15.0 & 15.0 & 15.0 & 15.38 \\
\hline Korea & 7.9 & 24.5 & 30.2 & 31.7 & 31.89 \\
\hline Abu Dhabi & & & & & 6.89 \\
\hline India & 0.9 & 0.7 & 0.6 & 0.4 & 0.30 \\
\hline Kuwait & 9.2 & 12.7 & 14.8 & 15.6 & 24.36 \\
\hline Treasury bill in US\$ to nonresidents & 0.0 & 0.0 & 50.0 & 0.0 & 0.0 \\
\hline IMF & 46.8 & 42.0 & 48.9 & 44.3 & 36.4 \\
\hline Commercial & 13.0 & 13.0 & 13.0 & 13.0 & 13.0 \\
\hline Short-term & 0.0 & 0.0 & 0.0 & 0.0 & 0.0 \\
\hline
\end{tabular}

Sources: Data provided by the Ministry of Finance; and Fund staff estimates. 


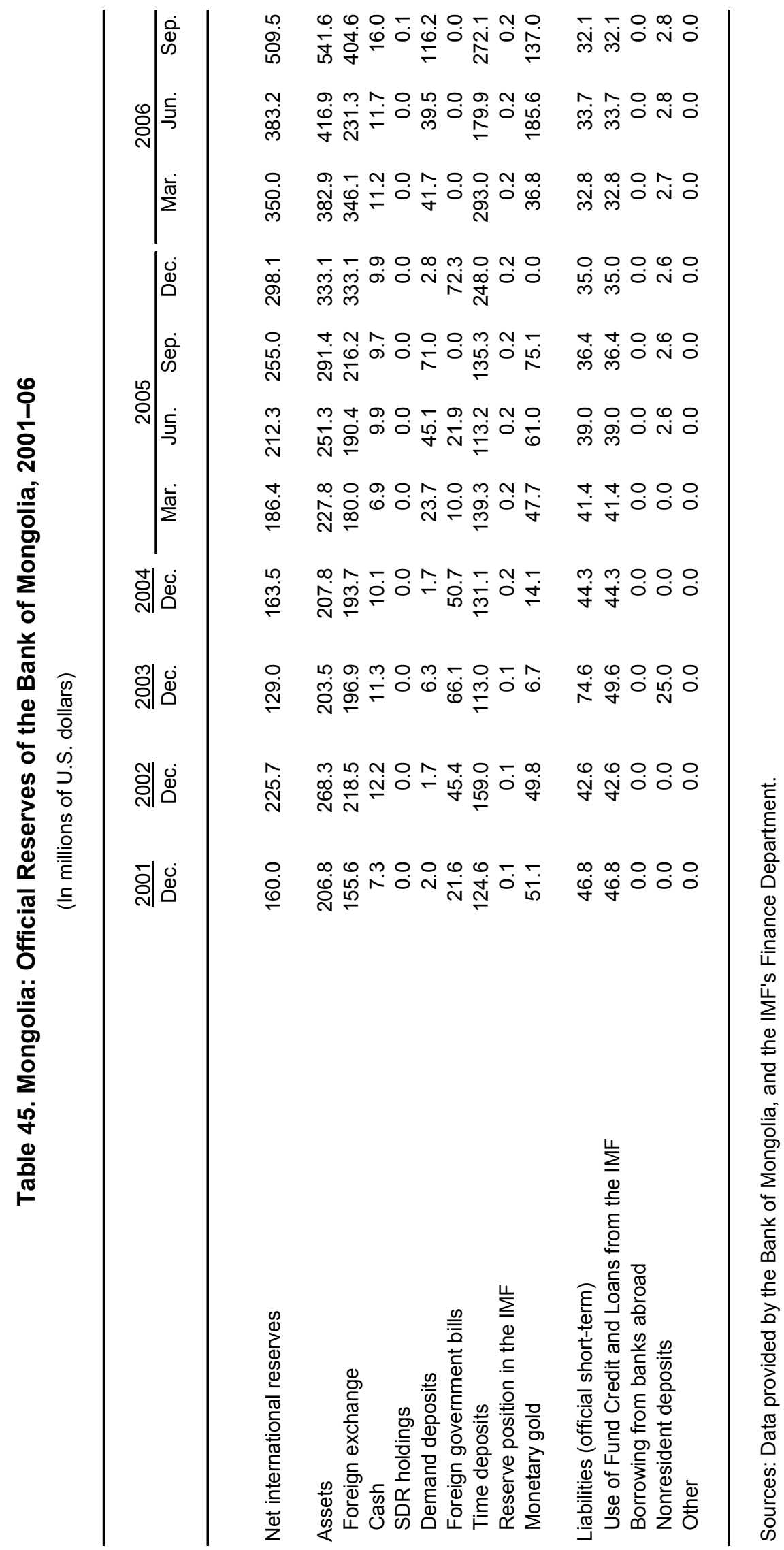


Table 46. Mongolia: Selected Indicators of Commercial Bank Foreign Exchange Operations, 2001-06

\begin{tabular}{|c|c|c|c|c|c|c|}
\hline & $\frac{2001}{\text { Dec. }}$ & $\frac{2002}{\text { Dec. }}$ & $\frac{2003}{\text { Dec. }}$ & $\frac{2004}{\text { Dec. }}$ & $\frac{2005}{\text { Dec. }}$ & $\frac{2006}{\text { Sep. }}$ \\
\hline Foreign assets (US\$ million) & 47.5 & 62.9 & 113.3 & 113.8 & 185.9 & 158.5 \\
\hline Cash & 6.6 & 11.2 & 15.2 & 23.2 & 24.5 & 30.3 \\
\hline Demand deposits & 13.2 & 17.3 & 33.0 & 27.2 & 49.4 & 41.0 \\
\hline Time deposits & 27.6 & 34.4 & 65.0 & 57.0 & 94.0 & 68.8 \\
\hline Other assets & 0.0 & 0.0 & 0.1 & 6.3 & 18.0 & 18.4 \\
\hline Foreign liabilities (US\$ million) & 8.0 & 14.6 & 44.0 & 44.4 & 44.9 & 43.0 \\
\hline Deposits of foreign banks and nonresidents & 1.5 & 2.7 & 3.9 & 34.0 & 32.9 & 34.4 \\
\hline Loans from foreign banks & 0.5 & 1.5 & 2.4 & 3.0 & 3.0 & 4.1 \\
\hline Other foreign liabilities & 6.0 & 10.4 & 37.8 & 7.3 & 9.1 & 4.5 \\
\hline \multicolumn{7}{|l|}{ Summary indicators (in percent) } \\
\hline FC loans/total loans & 36.4 & 37.0 & 42.4 & 44.8 & 45.2 & 44.6 \\
\hline Nonperforming loans/total loans (Forex) & 5.9 & 7.5 & 9.9 & 10.9 & 9.8 & 10.0 \\
\hline Nonperforming loans/total loans (tugrik) & 9.3 & 6.9 & 7.1 & 11.3 & 8.1 & 8.5 \\
\hline Foreign currency deposits (US\$ million) & 79.2 & 120.2 & 214.2 & 268.2 & 364.1 & 361.9 \\
\hline \multicolumn{7}{|l|}{ Summary indicators (in percent) } \\
\hline FC deposits/total deposits & 39.3 & 38.7 & 43.8 & 46.1 & 44.0 & 41.1 \\
\hline Forex current accounts/total current accounts & 46.2 & 48.9 & 61.0 & 58.2 & 63.1 & 57.2 \\
\hline FC demand deposits/total demand deposits & 51.6 & 48.6 & 49.3 & 56.9 & 48.9 & 46.3 \\
\hline FC time and savings deposits/total time and savings deposits & 29.6 & 27.6 & 29.7 & 37.8 & 30.5 & 29.9 \\
\hline
\end{tabular}

Source: Data provided by the Bank of Mongolia; and Fund staff estimates. 
Table 47. Mongolia: Nominal Exchange Rates, 2001-06

(In togrogs per U.S. dollar, period average)

\begin{tabular}{|c|c|c|c|}
\hline & Official rate $1 /$ & Interbank rate 2 / & Street rate \\
\hline 2001 & $1,097.6$ & $1,097.8$ & $1,098.7$ \\
\hline 2001 & $1,110.3$ & $1,110.7$ & $1,111.0$ \\
\hline 2003 & $1,146.5$ & $1,147.3$ & $1,147.7$ \\
\hline 2004 & $1,185.2$ & $1,186.7$ & $1,187.4$ \\
\hline \multicolumn{4}{|l|}{2005} \\
\hline $20041 Q$ & $1,173.6$ & $1,174.2$ & $1,174.3$ \\
\hline $2 Q$ & $1,167.6$ & $1,168.0$ & $1,168.7$ \\
\hline $3 Q$ & $1,190.8$ & $1,193.0$ & $1,193.5$ \\
\hline $4 Q$ & $1,208.8$ & $1,211.6$ & $1,212.9$ \\
\hline $20051 Q$ & $1,207.4$ & $1,208.8$ & $1,209.9$ \\
\hline $2 Q$ & $1,188.5$ & $1,189.3$ & $1,190.6$ \\
\hline $3 Q$ & $1,202.0$ & $1,204.5$ & $1,206.8$ \\
\hline $4 Q$ & $1,223.3$ & $1,225.5$ & $1,214.1$ \\
\hline $20061 Q$ & $1,204.7$ & $1,203.6$ & $1,204.8$ \\
\hline $2 Q$ & $1,180.1$ & $1,180.9$ & $1,181.5$ \\
\hline $3 Q$ & $1,168.8$ & $1,168.4$ & $1,169.8$ \\
\hline \multicolumn{4}{|l|}{2004} \\
\hline January & $1,170.2$ & $1,170.9$ & $1,171.0$ \\
\hline February & $1,173.2$ & $1,173.9$ & $1,174.0$ \\
\hline March & $1,177.5$ & $1,177.9$ & $1,178.0$ \\
\hline April & $1,173.0$ & $1,173.2$ & $1,174.0$ \\
\hline May & $1,163.2$ & $1,163.5$ & $1,164.0$ \\
\hline June & $1,166.6$ & $1,167.3$ & $1,168.0$ \\
\hline July & $1,181.8$ & $1,184.3$ & $1,185.0$ \\
\hline August & $1,191.6$ & $1,194.3$ & $1,195.0$ \\
\hline September & $1,198.9$ & $1,200.4$ & $1,200.5$ \\
\hline October & $1,204.4$ & $1,206.7$ & $1,207.2$ \\
\hline November & $1,210.2$ & $1,212.4$ & $1,215.0$ \\
\hline December & $1,211.8$ & $1,215.5$ & $1,216.6$ \\
\hline \multicolumn{4}{|l|}{2005} \\
\hline January & $1,210.9$ & $1,213.2$ & $1,215.4$ \\
\hline February & $1,208.5$ & $1,210.9$ & $1,212.7$ \\
\hline March & $1,202.7$ & $1,202.2$ & $1,201.7$ \\
\hline April & $1,186.9$ & $1,187.4$ & $1,189.1$ \\
\hline May & $1,188.0$ & $1,188.6$ & $1,189.6$ \\
\hline June & $1,190.5$ & $1,191.8$ & $1,193.1$ \\
\hline July & $1,193.5$ & $1,194.3$ & $1,196.0$ \\
\hline August & $1,200.2$ & $1,202.8$ & $1,204.8$ \\
\hline September & $1,212.4$ & $1,216.5$ & $1,219.6$ \\
\hline October & $1,218.8$ & $1,221.3$ & $1,224.2$ \\
\hline November & $1,224.4$ & $1,227.5$ & $1,188.3$ \\
\hline December & $1,226.6$ & $1,227.7$ & $1,229.8$ \\
\hline \multicolumn{4}{|l|}{2006} \\
\hline January & $1,220.5$ & $1,221.6$ & $1,224.3$ \\
\hline February & $1,210.2$ & $1,209.6$ & $1,210.0$ \\
\hline March & $1,183.2$ & $1,179.6$ & $1,180.2$ \\
\hline April & $1,186.3$ & $1,188.9$ & $1,189.7$ \\
\hline May & $1,182.5$ & $1,182.9$ & $1,182.9$ \\
\hline June & $1,171.5$ & $1,171.0$ & $1,171.9$ \\
\hline July & $1,170.3$ & $1,169.4$ & $1,171.2$ \\
\hline August & $1,168.4$ & $1,168.3$ & $1,169.9$ \\
\hline September & $1,167.7$ & $1,167.5$ & $1,168.5$ \\
\hline October & $1,166.6$ & $1,166.2$ & $1,167.3$ \\
\hline November & $1,164.1$ & $1,164.1$ & $1,165.2$ \\
\hline
\end{tabular}

Source: Data provided by the Bank of Mongolia.

1/ Midpoint rate announced by the Bank of Mongolia.

2/ Midpoint rate established in the interbank foreign exchange market. 